\title{
IDENTIFICATION OF FIRST-IN-CLASS INHIBITORS OF KALLIKREIN-RELATED PEPTIDASE 6 THAT PROMOTE OLIGODENDROCYTE DIFFERENTIATION
}

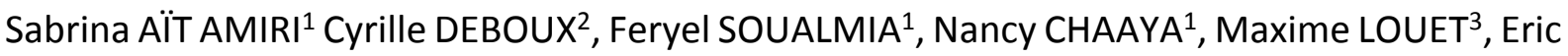 \\ DUPLUS ${ }^{1}$, Sandrine BETUING ${ }^{4}$, Brahim NAIT OUMESMAR ${ }^{2 *}$, Nicolas MASURIER ${ }^{3 *}$, Chahrazade \\ EL AMRI ${ }^{1 *}$
}

1. Sorbonne Université, Faculty of Sciences and Engineering, IBPS, UMR 8256 CNRSUPMC, ERL INSERM U1164, Biological Adaptation and Ageing, F-75252 Paris, France. Paris, France

2. Sorbonne Université, Inserm U 1127, CNRS UMR 7725, Institut du Cerveau, F-75013, Paris, France

3. Institut des Biomolécules Max Mousseron, Univ Montpellier, CNRS, ENSCM, Montpellier, France

4. Sorbonne Université, Faculty of Sciences and Engineering, IBPS, UMR 8246-CNRS / INSERM U1130 Neurosciences Paris Seine, F-75252 Paris, France. Paris, France

$\left({ }^{*}\right)$ Correspondence to C. El Amri (chahrazade.el amri@sorbonne-universite.fr), B. Nait Oumesmar (brahim.nait_oumesmar@ sorbonne-universite.fr); N. Masurier (nicolas.masurier@umontpellier.fr) 


\begin{abstract}
Multiple sclerosis (MS) is an autoimmune demyelinating disease of the central nervous system (CNS) that causes severe motor, sensory and cognitive impairments. KLK6 is the most abundant serine protease secreted in the CNS, mainly by oligodendrocytes, the myelinproducing cells of the CNS, and KLK6 is assumed to be a robust biomarker of MS, since it is highly increased in the cerebrospinal fluid (CSF) of MS patients. Here, we report the design and biological evaluation of KLK6's low-molecular weight inhibitors, para-aminobenzyl derivatives. Interestingly, selected hit compounds were selective of KLK6 proteolytic network encompassing KLK1 and plasmin that also participate to the development of MS physiopathology. Moreover, hits were found non-cytotoxic on primary cultures of murine neurons and oligodendrocyte precursors (OPCs). Among them, two compounds (32 and 42) were shown to promote the differentiation of OPCs into mature oligodendrocytes in vitro constituting thus emerging leads for the development of regenerative therapies.
\end{abstract}

Keywords: Kallikrein-related peptidase 6; synthetic inhibitors; mechanism of inhibition; polypharmacology; demyelinating diseases; oligodendrocytes' maturation. 


\section{Introduction}

Multiple sclerosis (MS) is a chronic inflammatory demyelinating disease of the central nervous system (CNS). MS affects more than two million people worldwide. ${ }^{1}$ In young adults, MS is the most common neurological disorder and the leading cause of severe non-traumatic disability. The main target of MS is the myelin sheath surrounding CNS axons in the brain, spinal cord and optic nerve. ${ }^{1}$ The myelin sheath is synthesized by oligodendrocytes that play a crucial role in the maintenance and functioning of neuronal networks. MS is associated with an inflammatory reaction of the CNS that results in degradation of the myelin sheath, therefore leading to diffuse demyelinating lesions. The consequences of this demyelination are multiple, nerve conduction is impaired and neurodegeneration occurs with disease progression. ${ }^{2}$ Moreover, myelin debris exacerbates the activation of immune pathways triggering demyelination. ${ }^{3}$ Clinically, these disturbances result in severe motor, sensory and cognitive deficits. The lack of a regenerative therapy that prevents disease progression represents the greatest unmet medical in MS. Disease-modifying drugs in the market are mainly targeting the inflammatory components of the pathology, but have little impact on oligodendrocyte regeneration and remyelination. ${ }^{4-6}$ The identification of new therapeutic compounds for MS-enhancing myelin repair is thus a critical public health issue. ${ }^{7,8} \mathrm{~A}$ special effort may be put on the search for pharmacological compounds, capable of simultaneously modulating neuroinflammation and promoting myelin regeneration for a more complete health care of MS patients. There is thus an urgent need to identify and validate novel targets to reach this issue.

In adults, under normal physiological conditions, kallikrein-related peptidase 6 (KLK6) is strongly expressed by oligodendrocytes and can be detected in neurons, whereas it is very weakly expressed in astrocytes and resting microglia. ${ }^{9}$ However, in response to a CNS lesion 
such as glutamate-induced excitotoxicity, inflammation or traumatic injury, the level of KLK6 expression rises in oligodendrocytes and neurons, and its expression is induced in reactive astrocytes and microglia. ${ }^{10}$ Among the 15 tissue kallikreins, KLK6 is the most abundant in the CNS, and is arguably the most abundant serine proteases produced in the CNS. ${ }^{11}$

KLK6 has a versatile action within the CNS. ${ }^{9}$ Interestingly, KLK6 cleaves myelin proteins, such as the myelin basic protein (MBP). KLK6 is a major protease of the process of demyelination/remyelination of axons. 9, 10,12 In addition to cleaving myelin proteins, KLK6 can also degrade blood-brain barrier components such as laminin, fibronectin and collagen, and induces inflammation via Protease Activated Receptors (PAR) activation and underlying intracellular $\mathrm{Ca}^{2+}$ mobilization. It should also be noted that the use of recombinant KLK6 in vitro contributes to neuronal lesions and oligodendrogliopathies. ${ }^{13}$ Some proteases have also been suggested for the activation of KLK6 in vivo, including plasmin, a serine protease involved in fibrinolysis. Finally, KLK6 is involved in oligodendrocyte differentiation and myelination processes. Different studies support that KLK6 is involved in the pathophysiology of MS. ${ }^{12-17}$ Firstly, patients with MS have abnormally high KLK6 levels in serum, cerebrospinal fluid (CSF) and demyelinating lesions, which demonstrate the implication of this protease at different levels of the pathology. ${ }^{18}$ Secondly, KLK6 induces demyelination, both through excessive cleavage of myelin proteins and deleterious effects on oligodendrocyte-process outgrowth and differentiation, thus leading to a drastic reduction in the number of myelinating oligodendrocytes. ${ }^{19}$ Third, KLK6 participates in the neuroinflammatory process through the overactivation of PAR receptors but also by increasing the expression of pro-inflammatory cytokines. Therefore, KLK6 participates in the establishment of a toxic environment that leads to demyelination and neurodegeneration, the main cause of disability progression in MS patients. ${ }^{19}$ KLK6 and KLK1 may also serve as serological markers of MS and may contribute 
directly to neurodegeneration. Furthermore, the immunization of mice with recombinant KLK6 antibodies significantly delayed onset and severity of clinical deficits in an experimental autoimmune encephalomyelitis (EAE) mouse model of MS. ${ }^{12,20}$ It is also well established that the potential significance of proteolytic activity in MS not only relates to their use as potential biomarkers but also as prospective therapeutic targets. The range of potential involvement of proteolytic activity in MS pathogenesis extends from parenchymal degenerative events including myelin destruction and axon injury, to release of antigenic self-epitopes, immune cell activation, and permeabilization of the blood-brain barrier. Scarisbrick and co-workers have proposed the term of MS degradome to encompass the set of proteases, substrates, and endogenous protease inhibitors involved in development and progression of MS. ${ }^{19}$

Scheme 1 summarizes the central role of KLK6 and its crosstalk with thrombolytic proteolytic pathways, thus illustrating the early concept of MS degradome. ${ }^{21}$ Particularly, it has been recently shown that plasminogen and plasmin-mediated fibrinolysis are key modifiers of the onset of neuroinflammatory demyelination. ${ }^{22,}{ }^{23}$ KLK1 was early shown to be a potential serological marker of progressive MS and contribute directly to the development of neurological disability by promoting axonal injury and neuron apoptosis. ${ }^{19}$ 


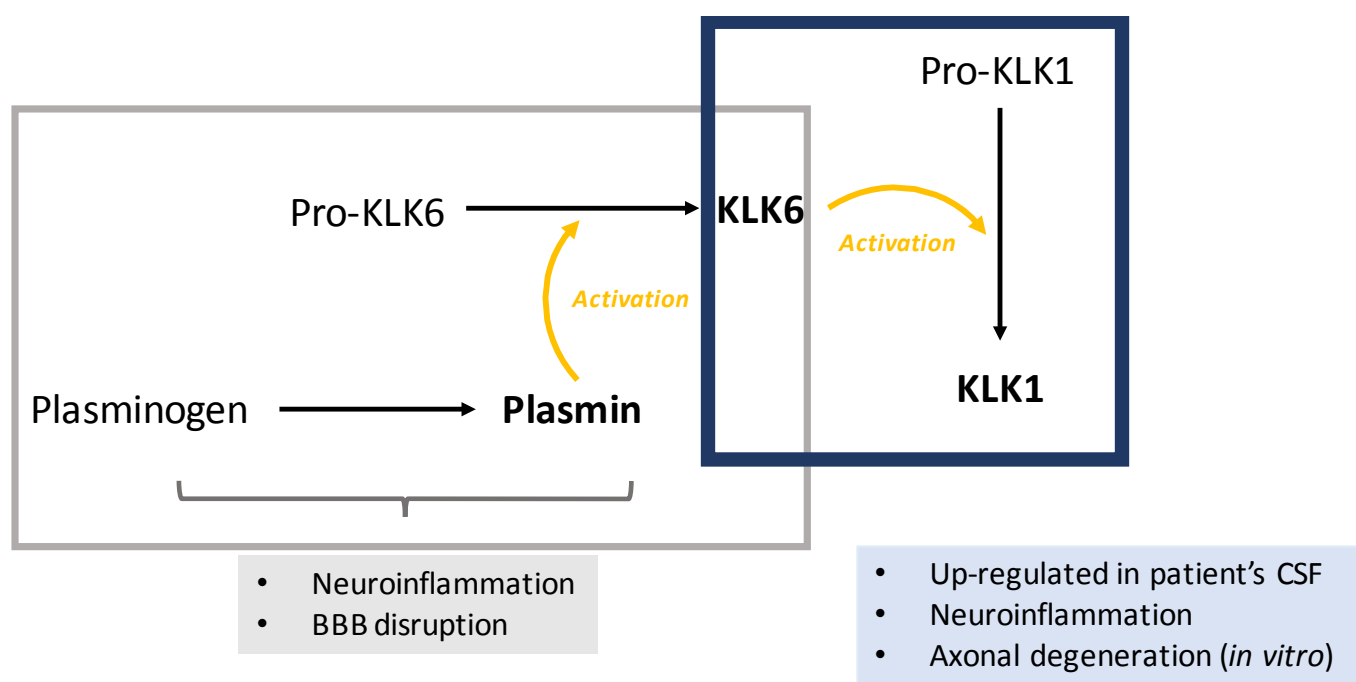

Scheme 1: Putative KLK6's pathological proteolytic network

In this context, the development of innovative inhibitors of KLK6 activity and its associated proteolytic network appears as a new therapeutic avenue.

The aim of this study is thus to identify potent KLK6 inhibitors encompassing the following properties: (i) reversibility, indeed non-covalent inhibitors, which are devoid of a reactive group, do not have the drawbacks generally associated with the presence of a warhead, such as lack of specificity, instability and excessive reactivity. Considering the physiological implication of KLK6 in the CNS homeostasis reversible inhibition would be safer, and (ii) able to inhibit other proteases involved in the KLK6 proteolysis network, i.e. KLK1 and plasmin. Herein, we identified and optimized original organic inhibitors for KLK6 and its proteolytic network. The designed low molecular weight inhibitors are potent and reversible towards KLK6, their inhibitory potency was also evaluated on a large panel of proteases. We also provided a detailed structure-activity relationship and dissected out the chemical basis for optimal inhibition. Hit compounds were found devoid of cytotoxic effects towards 
primary cultures of mouse neurons and oligodendrocyte precursors (OPCs), and displayed favorable drug-like characteristics. Interestingly, some hit compounds promoted OPC differentiation in vitro. These selected compounds constitute promising leads for the development of innovative myelination therapy.

\section{Results and Discussion}

\section{Rational design of para-benzylamine derivatives}

While the field of KLK's inhibitor discovery is relatively underdeveloped despite very huge interest in several therapeutic areas, recent reviews highlight the interest and need for further works. ${ }^{24-28}$

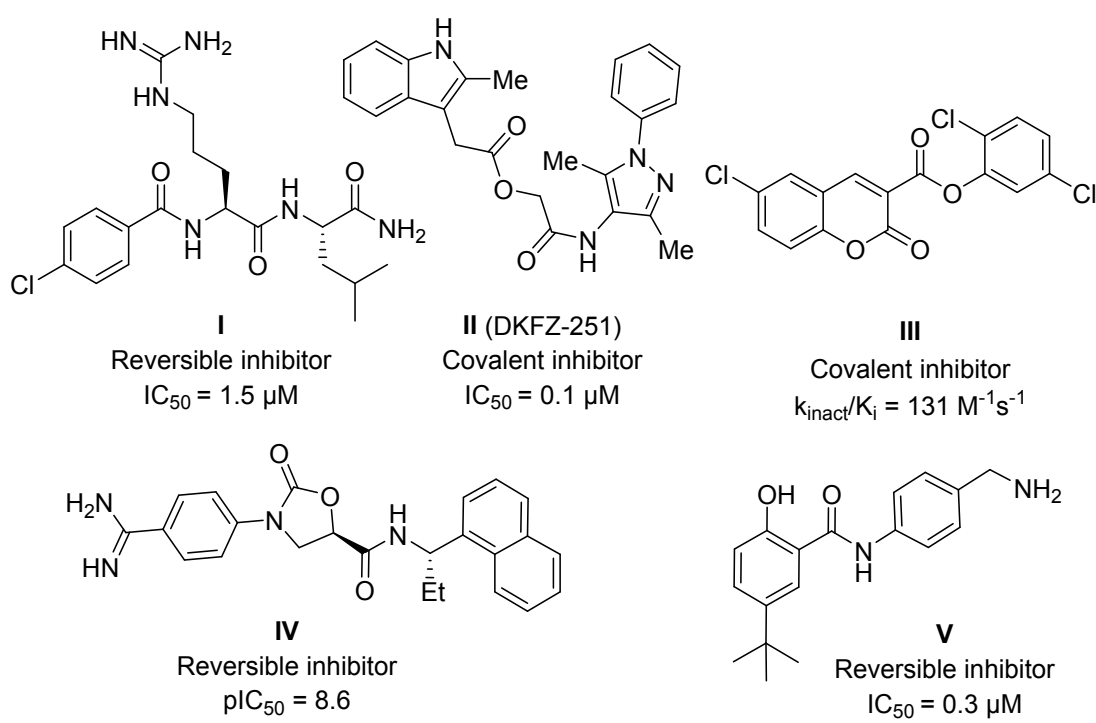

Chart 1: Main KLK6 inhibitors reported in the literature

A common approach for the development of inhibitors has been to use natural peptide inhibitors as starting points, exploiting combinatorial or designed mutations in order to achieve selectivity toward the targeted KLK (e.g. compound I, Chart 1). ${ }^{24,}{ }^{28}$ However, the development of subtype selective KLK inhibitors remains challenging. Papo and collaborators 
developed a yeast-displayed mutant library of the human amyloid precursor protein Kunitz protease inhibitor domain (APPI) to derive serine protease inhibitors especially of KLK6. ${ }^{29}$ Recently, Miller and co-workers have reported depsipeptides as potent KLK6's inhibitors to derive activity-based probes (Compound II, Chart 1). ${ }^{30}$ Our team has also recently identified 6-substituted coumarin-3-carboxylate derivatives as mechanism-based inhibitors (suicide substrates, compound III, Chart 1). ${ }^{31}$ Several small molecules were also reported as reversible inhibitors of KLK6. Among them, benzamidine and benzylamine derivatives are probably the most potent inhibitors (e.g. compounds IV and V, Chart 1). ${ }^{32,33}$ Especially, $\mathrm{N}$-(4-aminomethylphenyl)-2-hydroxy-benzamide derivatives reported by Liang and co-workers are easily accessible and can be subjected to a large chemical diversification for structure-activity relationship (SAR) studies. Moreover, these compounds can potentially provide access to submicromolar inhibitors. In this study, nine analogs were described and the 5-tert-butyl derivative (compound $\mathbf{V}$, Chart 1 ) revealed to be the most potent inhibitor of this series $\left(\mathrm{IC}_{50}\right.$ $=0.3 \mu \mathrm{M})$ constituting an initial hit. ${ }^{33}$ Substitution of the methylene group of the benzylamine as well as alkylation at the amino nitrogen led to inactive compounds, which clearly demonstrates that the amino group of the benzylamine is mandatory for the KLK6 inhibition. X-ray structure obtained with one of the derivatives of this series revealed that the benzylamine group bound into the S1 pocket of KLK6 by sharing a primary amine $\mathrm{H}$-bonding with the side chain of N189. The side chain of 1218 is also an important factor to the binding affinity through hydrophobic interaction with the phenyl ring of the benzylamine moiety. The hydroxyl group of the phenol occupied the center of the oxyanion hole, forming an $\mathrm{H}$-bonding network with the backbone NH groups of G193 and S195 (Figures 1A and B). Keeping constant these key elements involved in KLK6 interaction (Figure 1C), we synthesized and evaluated novel series of $\mathrm{N}$-(4-aminomethyl-phenyl)-2-hydroxy-benzamide and hydroxynaphtamide 
derivatives and identified drug-like reversible organic inhibitors of KLK6 and its associated proteolytic network.

A

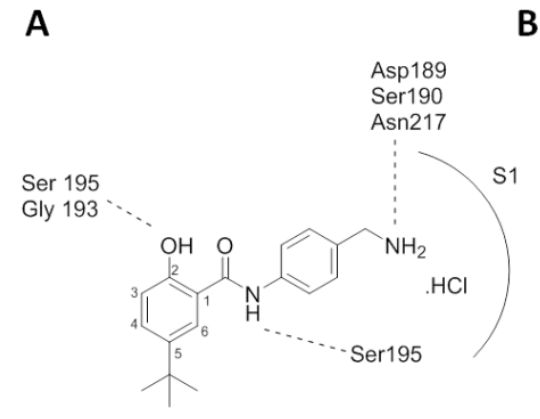
synthesized as reported in Scheme 2 . hydrochloride salts.
B

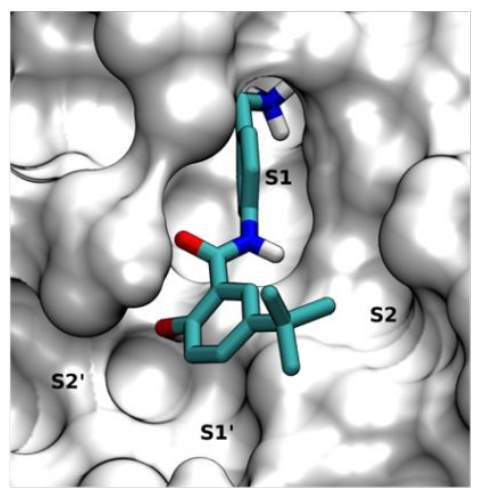

C

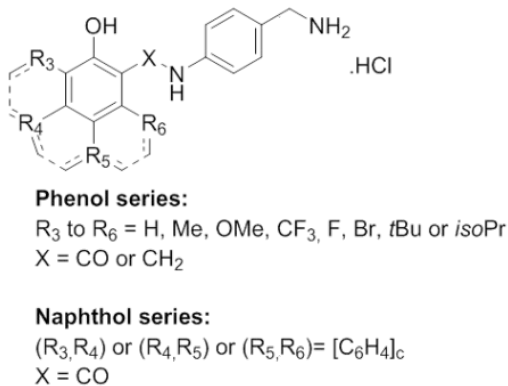

Figure 1: Rational design of para-amidobenzyl derivatives. A. Key interactions of compound $\mathbf{V}$ in the active site of KLK6 ( $\mathrm{H}$ bonds are shown as dashed lines); B. Positioning of compound $\mathbf{V}$ in the $\mathrm{S} 1$ and S1' pockets of KLK6; C. Structures of studied compounds.

Targeted compounds, as well as the reference compound $\mathbf{V}$ (now named compound 28) were

Briefly, compound $\mathbf{2}$ was obtained in two steps from 4-nitrobenzylamine hydrochloride after Boc protection of the amine group, followed by the reduction of the nitro function. Compound $\mathbf{2}$ was then coupled with the appropriate salicylic or naphtoic acid in presence of $\operatorname{EDCl}(N$-(3-dimethylaminopropyl)- $N$ '-ethylcarbodiimide hydrochloride) to offer compounds 3$\mathbf{2 5}$ in moderate yields. Compound $\mathbf{2 7}$ was synthesized by reductive amination with aldehyde 26 in presence of sodium borohydride. Reaction between 1-naphtoic acid, 1-Boc-4aminopiperidine and EDCl offered compound 52 in $64 \%$ yields. Finally, Boc group was removed using a mixture of hydrochloric acid in 1,4-dioxane to offer compounds $\mathbf{2 8 - 5 1}$ and $\mathbf{5 3}$ as 


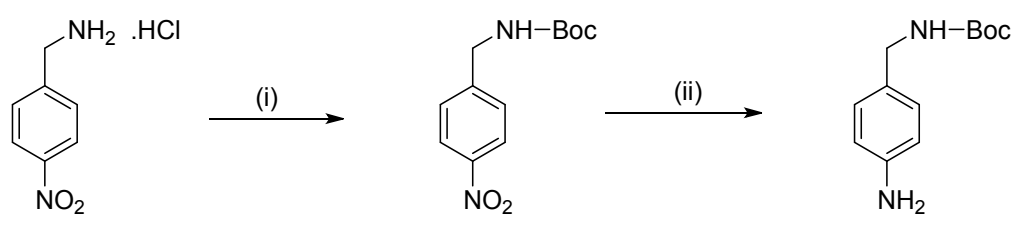

2
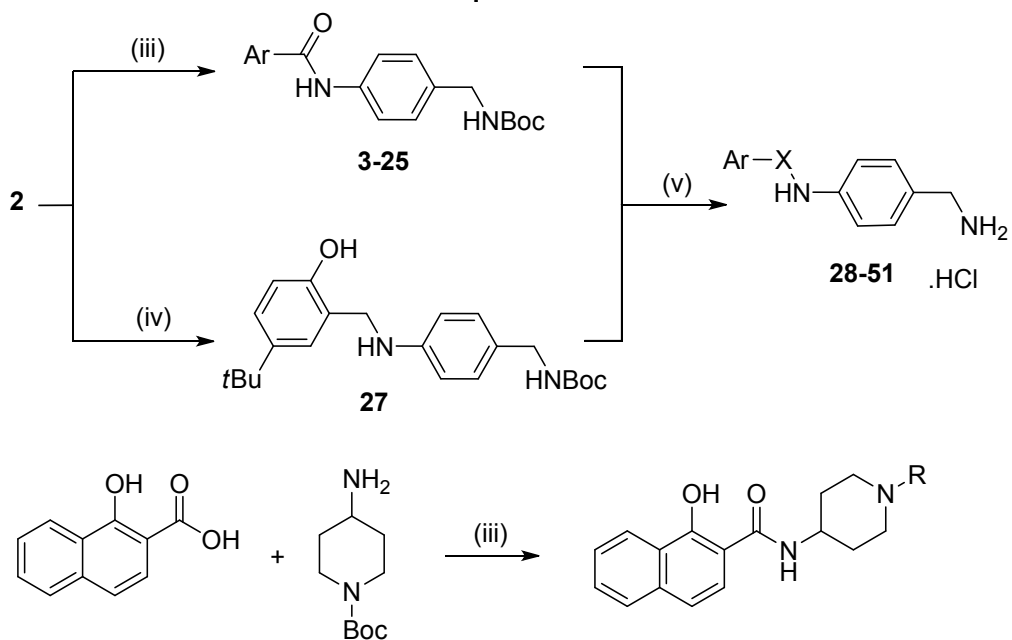

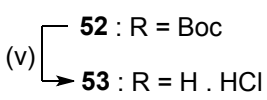

${ }^{a}$ Reagents and conditions: (i) $\mathrm{Boc}_{2} \mathrm{O}$, TEA, DCM, RT, 2h, 80\%; (ii) $\mathrm{H}_{2}, 10 \% \mathrm{Pd} / \mathrm{C}$, AcOEt, RT, 4h, qt; (iii) $\mathrm{ArCO}_{2} \mathrm{H}, \mathrm{EDCI}, \mathrm{THF}$, reflux, 12h, 12-82\%; (iv) 1. Compound 26, EtOH, reflux, 6h; 2. $\mathrm{NaBH}_{4}, \mathrm{RT}, 1.5 \mathrm{~h}, 64 \%$ and (v) $6 \mathrm{~N} \mathrm{HCl}$ gaz in 1,4-dioxane, RT, $1.5 \mathrm{~h}, 44-99 \%$.

Scheme 2: Synthesis of compounds 1 to 53

\section{Inhibitory potency hit compounds on KLK6 and on its proteolytic network}

Newly synthesized compounds $\mathbf{2 8 - 5 1}$ and $\mathbf{5 3}$ were first screened on KLK6 through the evaluation of the percentage inhibition at $10 \mu \mathrm{M}$. This allows highlighting the promising compounds for the inhibition of KLK6. Among the 25 designed compounds, we preselected those raising an inhibition of at least $50 \%$ of the activity of KLK6 at a concentration of $10 \mu \mathrm{M}$ and then determined their inhibitory potency through the quantification of $\mathrm{IC}_{50}$. 
Starting from reference compound $\mathbf{2 8}$ (Table 1) previously identified by Liang and al. (2012a), several modifications were studied in the phenol series, in order to determine key structural elements for KLK6 inhibition. Suppression of the carbonyl group (compound 29) as well as the tert-butyl group (compound $\mathbf{3 0}$ ) led to the loss of the activity. Then, sensitivity to the position of the substituent carried out by the phenol group was observed in the methyl series (compounds 31 to 34 ). Substitution of position 4 and position 5, in a less extent, were the most favorable to observe an optimal inhibition of KLK6. Several other groups were then introduced into $\mathrm{C} 4$ and $\mathrm{C} 5$. These positions must be substituted by an apolar or bulky group such as an isopropyl (compound 37) or a methyl group (compound 32) for C4 substituted derivatives and a tert-butyl group (compound 28) for C5 substituted derivatives. Interestingly, the substitution of the $\mathrm{C} 5$ position by a halogen (compound 35) or by a methoxy group (compound 36) is strongly unfavorable for the inhibition of KLK6.

When the inhibitor contains a naphthol group, a slight sensitivity with respect to the position of the hydroxyl group is observed. Indeed, it must be substituted at positions 1 or 3 for optimal inhibition of KLK6 (compounds 40 and 42 respectively). More generally, the hydroxyl group is essential because the inhibition of KLK6 decreases drastically when the inhibitor contains a naphthyl (compound 43) instead of a naphthol. This result is not surprising because, in the phenol series, the hydroxyl group was reported to be involved into key interactions notably with the S195 residue of KLK6. There is also a lack of inhibitory effect when the compound contains an indolyl (compound 44) or an oxoquinolyl ring (compound 45) in place of the naphthol ring, indicating that the hydroxyl group could not be replaced by another hydrogen donor or acceptor (NH or ketone). Moreover, we noted the importance of the benzylamine group. Indeed, we observed a significant decrease in the inhibition when this same position is occupied by a piperidinyl group (compound 53). Finally, several substitutions 
into the naphthol ring were studied (compounds $\mathbf{4 7}$ to $\mathbf{5 1}$, see supplementary information). However, all studied modifications led to autofluorescent compounds that could not be evaluated, except when a methoxy group was introduced on position 6 (compound 47). In this case, a slight loss of activity compared to its unsubstituted analog (compound 40) was observed.

Thus, among the new synthesized compounds, 5 new hits were identified in the series of para-aminobenzyl compounds (molecules 32, 37, 40, 42 and 47) (Table 1), displaying $I C_{50}$ equal or below $5 \mu \mathrm{M}$. The $\mathrm{IC}_{50}$ accounts for the effectiveness of the inhibitor with respect to the enzyme and allows a prioritization according to the inhibitory power. The $\mathrm{IC}_{50}$ values place compounds 32 and 42 at the top, while reference compound $28\left(\mathrm{IC}_{50}=9.06 \mu \mathrm{M}\right)$ has one of the lowest efficacy with respect to KLK6 among the selected inhibitors.

\begin{tabular}{|c|c|c|c|}
\hline Compound & $\mathrm{Ar}$ & $x$ & $\begin{array}{c}\text { \% Inhibition at } 10 \mu \mathrm{M} \\
\text { or } \mathrm{IC}_{50}(\mu \mathrm{M})\end{array}$ \\
\hline 28 & 5-tert-butyl-2-hydroxyphenyl & $\mathrm{CO}$ & $9.06 \pm 0.65$ \\
\hline 29 & 5-tert-butyl-2-hydroxyphenyl & $\mathrm{CH}_{2}$ & $\mathrm{NI}$ \\
\hline 30 & 2-hydroxyphenyl & $\mathrm{CO}$ & $14.83 \%$ \\
\hline 31 & 3-methyl-2-hydroxyphenyl & $\mathrm{CO}$ & $20 \%$ \\
\hline 32 & 4-methyl-2-hydroxyphenyl & $\mathrm{CO}$ & $2.37 \pm 0.12$ \\
\hline 33 & 5-methyl-2-hydroxyphenyl & $\mathrm{CO}$ & $26.47 \%$ \\
\hline 34 & 6-methyl-2-hydroxyphenyl & $\mathrm{CO}$ & $7.27 \%$ \\
\hline 35 & 5-bromo-2-hydroxyphenyl & $\mathrm{CO}$ & $29.98 \%$ \\
\hline 36 & 5-methoxy-2-hydroxyphenyl & $\mathrm{CO}$ & $21.83 \%$ \\
\hline 37 & 4-isopropyl-2-hydroxyphenyl & $\mathrm{CO}$ & $3.63 \pm 0.1$ \\
\hline 38 & 4-trifluoromethyl-2-hydroxyphenyl & $\mathrm{CO}$ & $47 \%$ \\
\hline
\end{tabular}




\begin{tabular}{|c|c|c|c|}
\hline 39 & 4-fluoro-2-hydroxyphenyl & $\mathrm{CO}$ & $\mathrm{NI}$ \\
\hline 40 & 1-hydroxy-2-naphthyl & $\mathrm{CO}$ & $6.90 \pm 0.24$ \\
\hline 41 & 2-hydroxy-1-naphthyl & $\mathrm{CO}$ & $\mathrm{NI}$ \\
\hline 42 & 3-hydroxy-2-naphthyl & $\mathrm{CO}$ & $1.57 \pm 0.03$ \\
\hline 43 & 2-naphthyl & $\mathrm{CO}$ & $19.81 \%$ \\
\hline 44 & 1-indolyl & $\mathrm{CO}$ & $\mathrm{NI}$ \\
\hline 45 & 4-oxo-3-quinolyl & $\mathrm{CO}$ & $\mathrm{NI}$ \\
\hline 46 & 2-pyridin-3-ol & $\mathrm{CO}$ & $8.86 \%$ \\
\hline 47 & 6-methoxy-1-hydroxy-2-naphthyl & $\mathrm{CO}$ & $7.18 \pm 0.33$ \\
\hline Compound & $\mathrm{Ar}$ & & $\%$ Inhibition at $10 \mu \mathrm{M}$ \\
\hline 53 & 1-hydroxy-2-naphthyl & & $\mathrm{NI}$ \\
\hline
\end{tabular}

2 3 
Table 1: Efficacy of para-aminobenzyl compounds towards KLK6. For each compound, the inhibitory effect was quantified either by the percentage inhibition of KLK6 at $10 \mu \mathrm{M}$, or by the $\mathrm{IC}_{50}$ for compound hits. To determine the $\mathrm{IC}_{50}$, compounds at different concentrations (concentration ranges adjusted depending of the inhibitory potency) are pre-incubated 15 minutes at $37^{\circ} \mathrm{C}$ with KLK6 $(2 \mathrm{nM})$. The enzymatic reaction is triggered by the addition of the Boc-QAR-AMC substrate $(100 \mu \mathrm{M})$ in $50 \mathrm{mM}$ Tris buffer, $1 \mathrm{M}$ Citrate $0.05 \% \mathrm{Brij}-35 ; \mathrm{pH} 7.4$ at $37^{\circ} \mathrm{C}$. NA: not applicable. NI: non-inhibitor. The data result from at least three independent experiments in duplicate. The $\mathrm{IC}_{50}$ values were calculated by fitting the experimental data to eq. $2 \mathrm{a}$ or eq.2b and expressed as geometric standard deviation.

Then, we assessed inhibitory potency of our hit compounds $(32,37,40,42$ and 47$)$ and of reference compound $\mathbf{2 8}$ towards KLK1 and plasmin, as these two proteases are thought to be part of the proteolytic network of KLK6 in MS. ${ }^{19}$ All these para-aminobenzyl derivatives lead to at least $50 \%$ inhibition of the plasmin activity except inhibitor $28(45 \%)$ while all the tested inhibitors lead to an inhibition of at least $50 \%$ of KLK1 activity at a concentration of $10 \mu \mathrm{M}$ (data not shown). The inhibitory potency $\left(\mathrm{IC}_{50}\right)$ of hit compounds was then determined. The $I C_{50}$ values with respect to plasmin place compound $47\left(I C_{50}=3.3 \mu \mathrm{M}\right)$ at the top while reference compound $28\left(I C_{50}=21.3 \mu \mathrm{M}\right)$ has one of the lowest efficiency (Table 2). At the same time, compound 42 is characterized by and $\mathrm{IC}_{50}$ value of $5.1 \mu \mathrm{M}$ towards KLK1, while other compounds showed lower inhibitory potency and were thus not selected for further mechanistic studies (Table 2). 


\begin{tabular}{|c|c|c|c|c|}
\hline$\overbrace{1}$ & & & \multicolumn{2}{|c|}{$I C_{50}(\mu \mathrm{M})$} \\
\hline Compound & $\mathrm{Ar}$ & $x$ & Plasmin & KLK1 \\
\hline 28 & 5-tert-butyl-2-hydroxyphenyl & $\mathrm{CO}$ & $21.3 \pm 3.6$ & $38.6 \pm 1.9$ \\
\hline 32 & $\begin{array}{l}\text { 4-methyl-2- } \\
\text { Hydroxyphenyl }\end{array}$ & $\mathrm{CO}$ & $9.2 \pm 0.6$ & $26.3 \pm 1.1$ \\
\hline 37 & $\begin{array}{l}\text { 4-isopropyl-2- } \\
\text { Hydroxyphenyl }\end{array}$ & $\mathrm{CO}$ & $4.8 \pm 0.2$ & $8.4 \pm 0.3$ \\
\hline 40 & $\begin{array}{l}\text { 1-hydroxy-2- } \\
\text { Naphthyl }\end{array}$ & $\mathrm{CO}$ & $10.2 \pm 0.6$ & $21.3 \pm 1.6$ \\
\hline 42 & $\begin{array}{l}\text { 3-hydroxy-2- } \\
\text { Naphthyl }\end{array}$ & $\mathrm{CO}$ & $7.4 \pm 0.6$ & $5.1 \pm 0.2$ \\
\hline 47 & $\begin{array}{l}\text { 6-methoxy-1- } \\
\text { hydroxy-2-naphthyl }\end{array}$ & $\mathrm{CO}$ & $3.3 \pm 0.2$ & $16.1 \pm 0.4$ \\
\hline 49 & $\begin{array}{l}\text { 7-methyl-1-hydroxy- } \\
\text { 2-naphthyl }\end{array}$ & $\mathrm{CO}$ & $6.7 \pm 0.6$ & $49.4 \pm 4$ \\
\hline
\end{tabular}

Table 2: Efficacy of KLK6 para-amino benzyl hit inhibitors on Plasmin and KLK1. For each compound, the inhibitory effect was quantified by the $\mathrm{IC}_{50}$. To determine the $\mathrm{IC}_{50}$, compounds at different concentrations (from 100 to $1.56 \mu \mathrm{M}$ ) are pre-incubated 15 minutes at $37^{\circ} \mathrm{C}$ with Plasmin $(3 \mathrm{nM}$ ) or KLK1 $(0,75 \mathrm{nM})$ in $50 \mathrm{mM}$ Tris buffer, $1 \mathrm{M}$ Citrate $0.05 \% \mathrm{Brij}-35 ; \mathrm{pH} 7.4$ at $37^{\circ} \mathrm{C}$. The enzymatic reaction is then triggered by the addition of the Boc-QAR-AMC substrate $(100 \mu \mathrm{M})$ for Plasmin and H-PFR-AMC substrate $(100 \mu \mathrm{M})$ for KLK1. The data result from at least three independent experiments in duplicate. The $\mathrm{IC}_{50}$ values were calculated by fitting the experimental data to eq. $2 \mathrm{a}$ or eq.2b and expressed as geometric standard deviation.

Hit compounds $(32,37,40,42,47,49)$ and reference compound 28 were assessed by the evaluation of their selectivity spectrum against a set serine proteases and proteases involved in CNS homeostasis. Table 3 provides an overview of putative cross-inhibition within a large set of proteases both serine proteases challenging in the CNS (KLK8, tPA, thrombin, trypsin, trypsin 3, KLK11) but also other kallikreins (KLK3, KLK4, KLK5, KLK14), matriptase, and diverse 
proteases involved in CNS inflammation (Caspase-2, Caspase-3, Caspase-6, Cathepsin L). Overall, this screening shows that hit compounds $\mathbf{3 2}$ and $\mathbf{4 2}$ have little effect on these selected challenging proteases in contrast to the other identified inhibitors $(\mathbf{2 8}, \mathbf{3 7}, \mathbf{4 0}, \mathbf{4 7}, \mathbf{4 9})$ that display significant inhibition on several proteases. This allows to conclude that compounds 32 and $\mathbf{4 2}$ are quite specific to KLK6 and its proximal proteolytic network.

\begin{tabular}{|c|c|c|c|c|c|c|c|}
\hline Inhibitor & $\mathbf{2 8}$ & $\mathbf{3 2}$ & $\mathbf{3 7}$ & $\mathbf{4 0}$ & $\mathbf{4 2}$ & $\mathbf{4 7}$ & $\mathbf{4 9}$ \\
\hline Protease & & & & & & & \\
\hline KLK4 & 0 & 0 & 45 & 14 & 2 & 3 & 6 \\
\hline KLK5 & 35 & 5 & 24 & 22 & 4 & 31 & 0 \\
\hline KLK7 & 9 & 12 & 7 & 0 & 6 & 10 & 11 \\
\hline KLK8* & 16 & 34 & $\mathbf{5 8}$ & 22 & $\mathbf{6 1}$ & 45 & $\mathbf{5 3}$ \\
\hline KLK11* & $\mathbf{5 6}$ & 39 & $\mathbf{7 5}$ & $\mathbf{8 0}$ & 45 & 0 & $\mathbf{8 8}$ \\
\hline KLK13 & 5 & 10 & 15 & 2 & 19 & 0 & 12 \\
\hline KLK14 & 1.5 & 3 & 12 & 11 & 5 & 16 & 4 \\
\hline Caspase-2* & 5 & 0 & 15 & 30 & 4 & 14 & 8 \\
\hline Caspase-3 & 11 & 0 & 13 & 10 & 5 & 3 & 10 \\
\hline Caspase-6* & 13 & 5 & 12 & $\mathbf{5 6}$ & 40 & $\mathbf{7 0}$ & 31 \\
\hline Cathepsin L* & 20 & 32 & 1 & 30 & 25 & 28 & 27 \\
\hline Matriptase & 0 & 0 & 13 & 29 & 8 & 37 & 0 \\
\hline Thrombin & 2 & 0 & 32 & 5 & 0 & 6 & 6 \\
\hline tPA & 11 & 0 & 6 & 18 & 6 & 10 & 9 \\
\hline Trypsin & 5 & 15 & $\mathbf{9 1}$ & 34 & 25 & 41 & 32 \\
\hline Trypsin 3* & 15 & 20 & $\mathbf{7 3}$ & 30 & 36 & 32 & 21 \\
\hline
\end{tabular}

Table 3: Selectivity of the inhibition of hit compounds toward selected CNS concurrent proteases (Inhibition percentage at $\mathbf{1 0} \mu \mathrm{M}, \%)$. Each inhibitor $(10 \mu \mathrm{M})$ is preincubated with the enzyme at the optimal concentration for 15 minutes at $37^{\circ} \mathrm{C}$. The reaction is triggered by the addition of the specific AMC-substrate in the appropriate buffer (cf section "Material and Methods - Selectivity profiling"). The data result from at least three independent experiments with a standard deviation $<10 \%$. Proteases implicated in the CNS physiological processes. Gray light: significative percentage of inhibition. 


\section{Mechanism of inhibition: hit compounds}

Mechanistic studies were only performed for hit compound that display an ideal balance between potency and selectivity profiles towards KLK6 and its proximal proteolytic network (KLK1 and Plasmin) as well as the reference compound $\mathbf{2 8}$ for comparison. The reversibility of the inhibitions exerted by the compounds on KLK6 and its proteolytic network (Plasmin and KLK1) were demonstrated by the dilution method as described in the "Materials and methods" section. This experiment distinguishes an irreversible covalent inhibitor from a reversible one. Whatever the compound tested, a 1/100 dilution of the enzyme-inhibitor complex allowed restoring the initial activity of KLK6 to more than $80 \%$. Hence, hit compounds are reversible inhibitors (Figure 2). The mechanisms were determined using representations of Dixon for hits and reference compounds. The results are shown in Figure 2. The Dixon graphs obtained for compounds 28, 32 and 40 (Figures $2 \mathrm{~A}, \mathbf{2 B}$ and $2 \mathrm{C}$ ) are typical of competitive inhibitors. Compounds 28, 32 and 40 have $K_{i}$ values of $4.3 \mu \mathrm{M}, 2 \mu \mathrm{M}$ and $2.4 \mu \mathrm{M}$, respectively. Surprisingly the mechanistic profile of compound $\mathbf{4 2}$ was found compatible with a noncompetitive inhibition with a $\mathrm{K}_{\mathrm{i}}$ value of $0.8 \mu \mathrm{M}$ which may be indicative of a more complex binding (Figures 2D). The Dixon plots for compounds 37 and 47 are provided in the supplementary data section (Figure S1). 

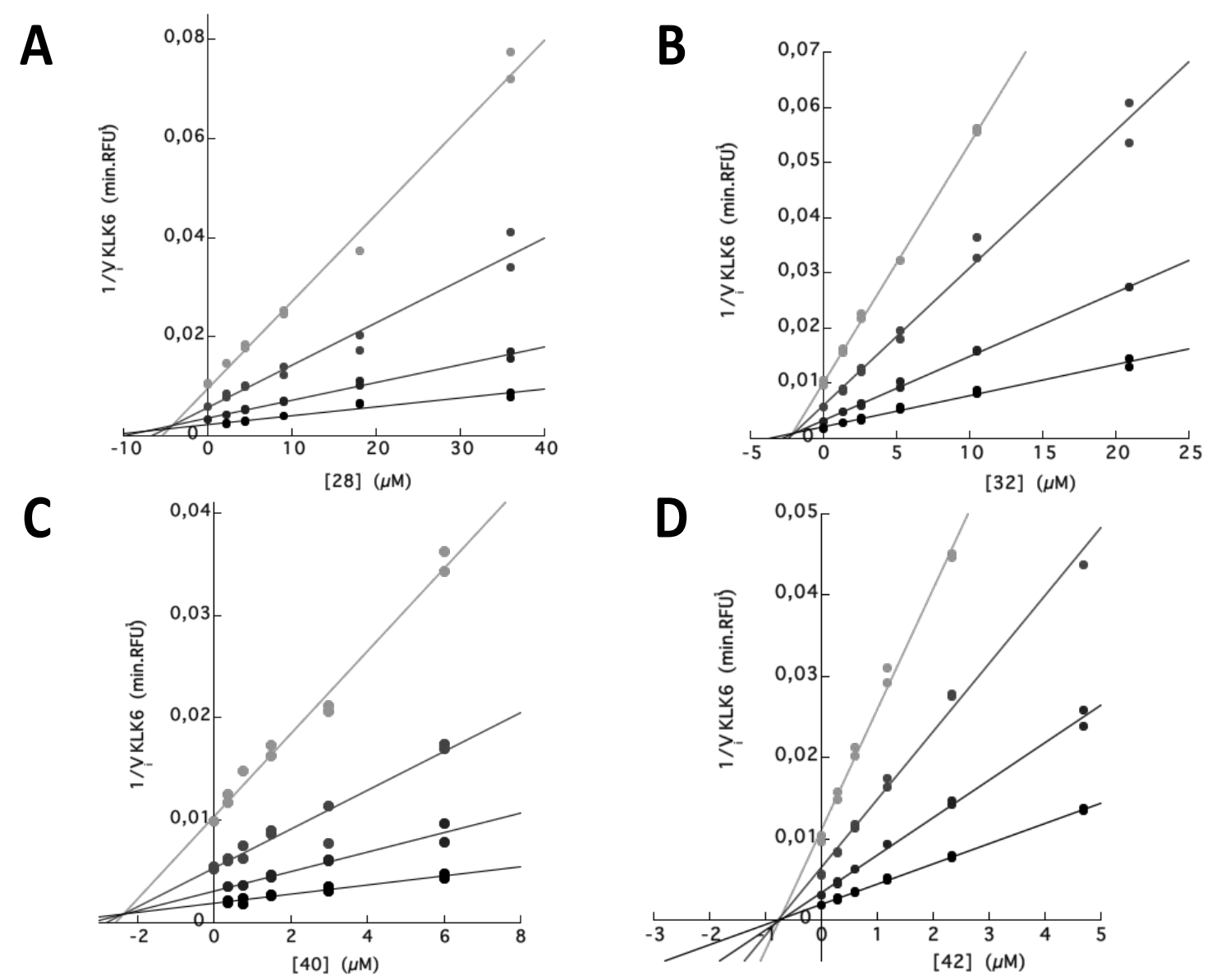

Figure 2: Mechanisms of inhibition towards KLK6. Dixon plots for inhibitors $28(A), 32$ (B), 40 (C) and 42 (D). Inhibitors at different concentrations $\left(1 / 4 ; 1 / 2 ; 1 ; 2 ; 4\right.$ of the IC $C_{50}$ value) were tested using 2 nM KLK6 with substrate Boc-QAR-AMC at different concentrations $(125 ; 62.5$; $31.25 ; 15.625 \mu \mathrm{M})$ in $50 \mathrm{mM}$ Tris, $1 \mathrm{M}$ Citrate, $0.05 \%$ Brij-35, pH 7 buffer at $37^{\circ} \mathrm{C}$.

Concerning plasmin and KLK1, all compounds are reversible inhibitors as shown using the dilution method. Dixon plots obtained for compounds $\mathbf{2 8 ,} 40$ and $\mathbf{4 2}$ (Figures 3A, 3B and 3C) are typical of competitive inhibitors towards plasmin. Compounds $\mathbf{2 8 ,} \mathbf{4 0}$ and $\mathbf{4 2}$ have $\mathrm{K}_{\mathrm{i}}$ values of $14.5 \mu \mathrm{M}, 1.5 \mu \mathrm{M}$ and 1.3 $\mu \mathrm{M}$ respectively. The Dixon plot for KLK1 obtained with inhibitor 42 is also typical of a competitive inhibitor ( $\mathrm{Ki}=2.4 \mu \mathrm{M})$ (Figure 3D and Table 4). Hence, it is shown that some of our hit KLK6 inhibitors also target key serine proteases of KLK6 proteolytic network with a relatively good affinity, which may constitute interesting perspective for a polypharmacological strategy. 


\begin{tabular}{|c|c|c|c|c|c|c|}
\hline & \multicolumn{2}{|c|}{ KLK6 } & \multicolumn{2}{c|}{ Plasmin } & \multicolumn{2}{c|}{ KLK1 } \\
\hline Compound & $\begin{array}{c}\text { Type of } \\
\text { inhibition }\end{array}$ & $\mathbf{K}_{\mathrm{i}}(\boldsymbol{\mu} \mathrm{M})$ & $\begin{array}{c}\text { Type of } \\
\text { inhibition }\end{array}$ & $\mathbf{K}_{\mathrm{i}}(\boldsymbol{\mu} \mathrm{M})$ & $\begin{array}{c}\text { Type of } \\
\text { inhibition }\end{array}$ & $\mathbf{K}_{\mathrm{i}}(\boldsymbol{\mu} \mathrm{M})$ \\
\hline $\mathbf{2 8}$ & Competitive & $4.3 \pm 1.6$ & Competitive & $14.5 \pm 1.2$ & NA & NA \\
\hline $\mathbf{3 2}$ & Competitive & $2 \pm 0.5$ & NA & NA & NA & NA \\
\hline $\mathbf{3 7}$ & Competitive & $1.5 \pm 0.2$ & NA & NA & NA & NA \\
\hline $\mathbf{4 0}$ & Competitive & $2.4 \pm 0.1$ & Competitive & $1.5 \pm 0.5$ & NA & NA \\
\hline
\end{tabular}

A

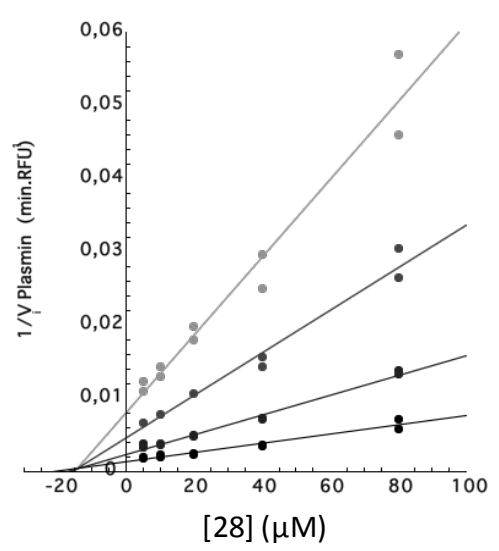

C

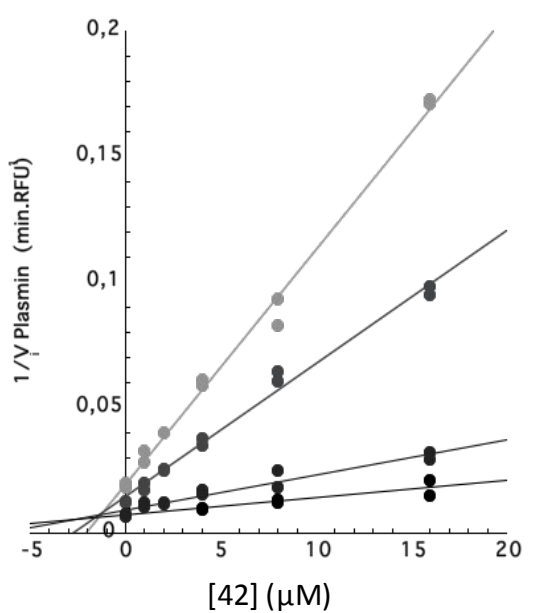

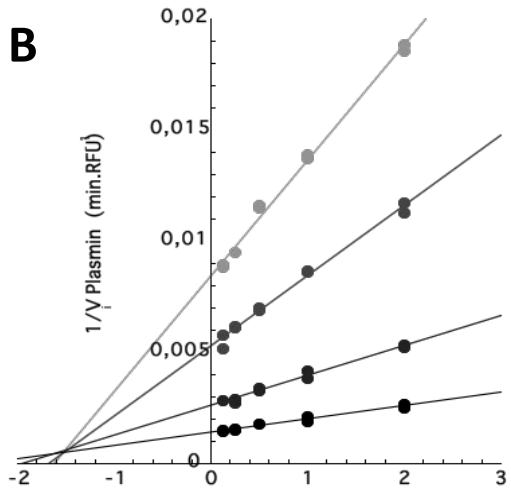

[40] $(\mu \mathrm{M})$

D

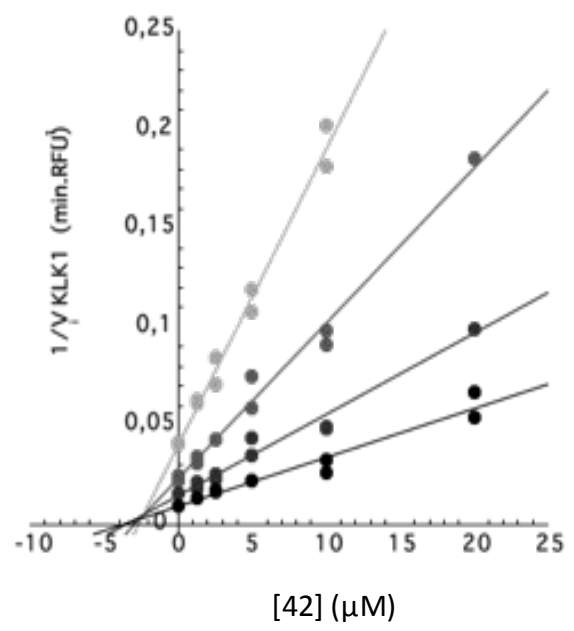

Figure 3: Mechanisms of inhibition towards KLK1 and plasmin. (A-C) Dixon plots for inhibitors $28(A)$, 40 (B), 42 (C) towards plasmin. (D) Dixon plot for inhibitor 42 towards KLK1. Inhibitors at concentrations $(1 / 4 ; 1 / 2 ; 1 ; 2 ; 4$ of the IC 50 value) were tested on plasmin $(3 \mathrm{nM})$ or KLK1 $(0,75 \mathrm{nM})$ with respectively Boc-QAR-AMC or H-PFR-AMC substrates at concentrations $(125 ; 62.5 ; 31.25 ; 15.625$ $\mu \mathrm{M})$ in $50 \mathrm{mM}$ Tris buffer, $1 \mathrm{M}$ Citrate, $0.05 \% \mathrm{Brij}-35, \mathrm{pH} 7$ at $37^{\circ} \mathrm{C}$. 


\begin{tabular}{|c|c|c|c|c|c|c|}
\hline $\mathbf{4 2}$ & $\begin{array}{c}\text { Non- } \\
\text { competitive }\end{array}$ & $0.8 \pm 0.3$ & Competitive & $1.3 \pm 0.53$ & Competitive & $2.4 \pm 0.5$ \\
\hline $\mathbf{4 7}$ & Competitive & $1 \pm 0,3$ & NA & NA & NA & NA \\
\hline
\end{tabular}

Table 4: Mechanisms of inhibition and $K_{i}$ values of hit compounds on KLK6 and its associated proteolytic network (KLK1 and plasmin). NA, not applicable

\section{Evaluation of the cytotoxicity of hit compounds toward neural cells}

To ensure that hit compounds (32, 40 and $\mathbf{4 2}$ ) may constitute good starting points for further applications, their potential cytotoxicity toward neural cells was first evaluated in comparison to reference compound $\mathbf{2 8}$ on primary cultures of mouse cortical and striatal neurons at 10, 25, 50 and $100 \mu \mathrm{M}$ (Figure 4A). Compounds 32 and $\mathbf{4 2}$ showed similar effects on both cortical and striatal neurons. A slight effect is observed from a concentration of $50 \mu \mathrm{M}$ of inhibitors 32 and $\mathbf{4 2}$, with percentages of cell survival around $65-70 \%$. In contrast, compound $\mathbf{4 0}$ is the only compound showing a cytotoxic effect on striatal neurons from a concentration of $10 \mu \mathrm{M}$, this cytotoxicity is stable over the concentration range meaning that a plateau may be reached (Figure 4B). Thus, these newly identified inhibitors are all very poorly cytotoxic in comparison with the reference inhibitor $\mathbf{2 8}$, which displays a noticeable cytotoxic effect, even at $25 \mu \mathrm{M}$, very close to the treatment with rotenone vehicle at $50 \mu \mathrm{M}$.

Hence, since compounds $\mathbf{3 2}, \mathbf{4 0}$ and $\mathbf{4 2}$ did not show toxic effects towards neurons, they were selected for further studies in oligodendrocyte precursor cell (OPC) cultures as relevant biological model for MS. 
A
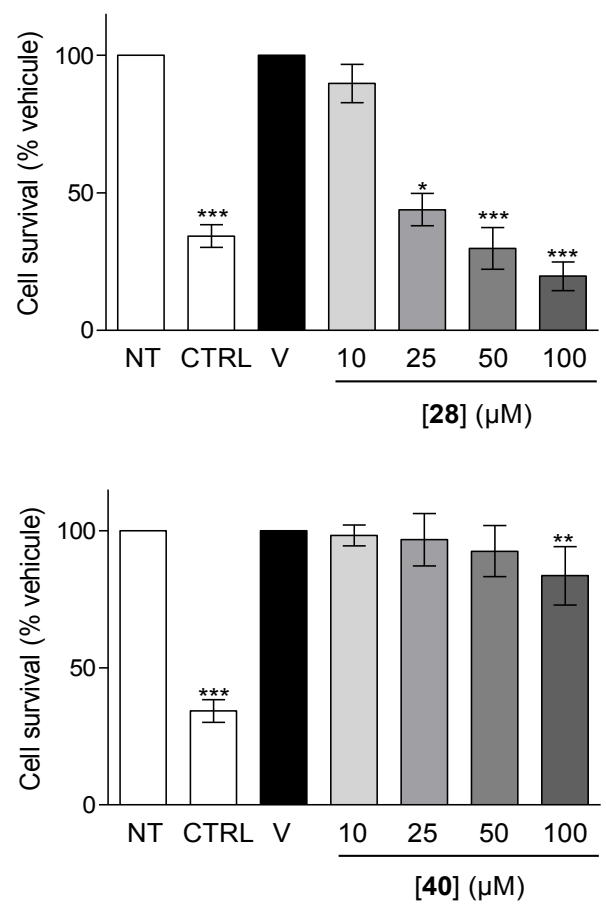

B
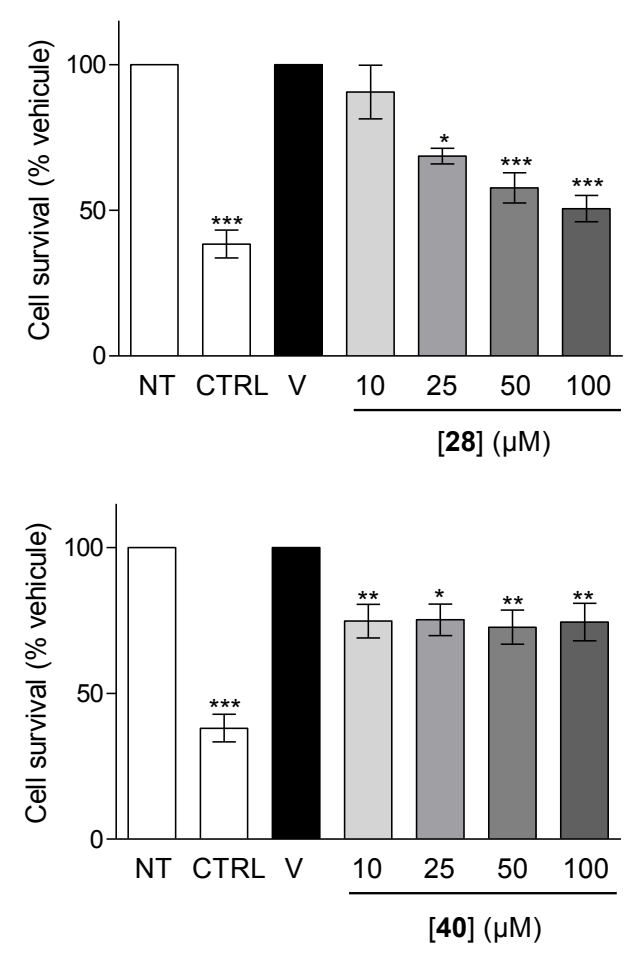
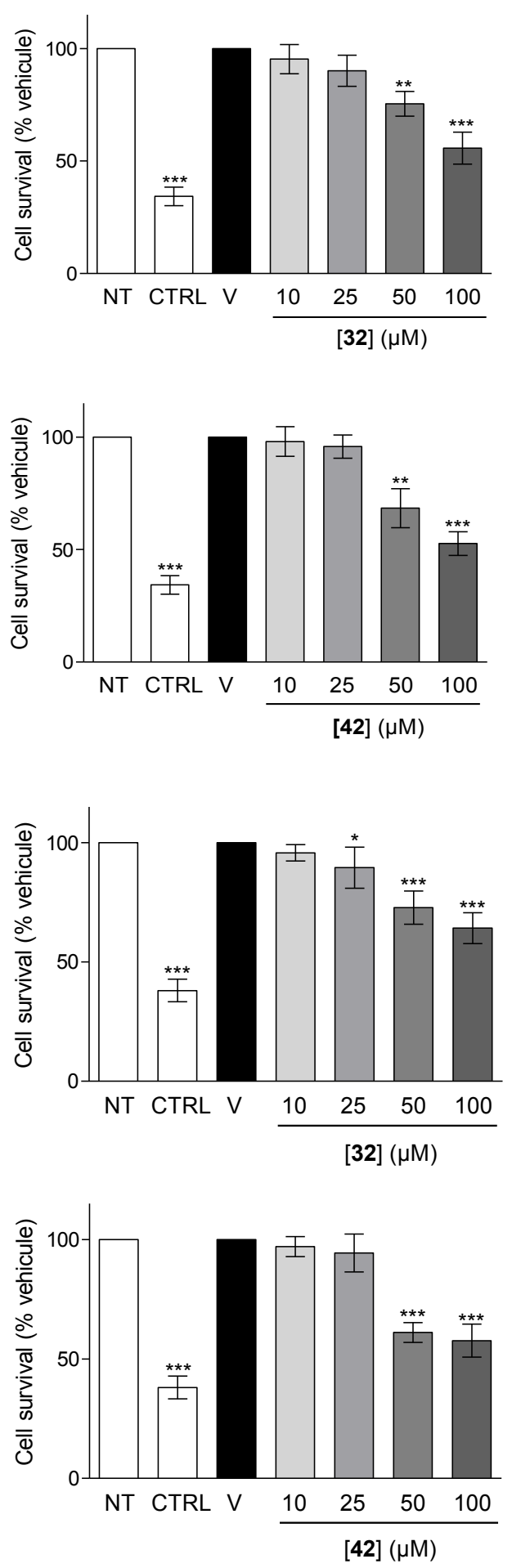

Figure 4: Cytotoxicity of hit inhibitors (32, 40 and 42) and reference compound 28 against primary cultures of cortical and striatal neurons. A - Cortical neurons. B- Striatal neurons. Primary cultures were treated either with inhibitors in a concentration range from $10 \mu \mathrm{M}$ to $100 \mu \mathrm{M}$ or with the vehicle (DMSO 1\%, "V") or with rotenone $50 \mu \mathrm{M}$ (CTRL) for 24 hours ( $\mathrm{N}=3$ ). Cell survival was then measured using XTT assay. All data sets were compared to the vehicle condition (V) for the generation of the $p$ values. ${ }^{*} \mathrm{p}$-value $<0.05 ;{ }^{* *} \mathrm{p}$-value $<0.01 ; * * \mathrm{p}$-value $<0.001$ (Kruskal-Wallis test). NT: no treatment 


\section{Pro-differentiating effect of hit compounds}

Oligodendrocytes are derived from OPCs, a class of progenitors highly abundant during development but also persistent in the adult CNS, where they contribute to myelin remodelling and remyelination following acute demyelination. Although efficient remyelination occurs in the early stages of MS, it becomes inefficient and ultimately fails with disease progression. Remyelination requires the generation of new mature oligodendrocytes (OLs) from OPCs that must be recruited to the demyelinated lesions. Over the last decade, there have been huge interest in developing medicines to improve remyelination in MS. ${ }^{34}$ The approaches range widely, from developing novel medicines and repurposing existing drugs. We thus assayed hit compounds on CG4 cell line and rat OPC primary cultures to check for their ability to induce differentiation. To monitor OPC differentiation, we developed a stable CG4 cell line expressing the GFP reporter at all stages of the oligodendroglial lineage cells and the mCherry reporter only in mature oligodendrocytes (Figure 5A). This innovative cellular assay allows the screening of promyelinating compounds based on the detection of fluorescence parameters. Indeed, both morphological changes and generation of mature oligodendrocytes can be monitored in a single assay, based on EGFP and mCherry fluorescence, respectively. After few days in basal medium, CG4 cells start to differentiate and expressed mCherry (Figure 5B, 5C). Fluorescence imaging (90 image fields were acquired for each condition) and quantification were performed with the Arrayscan XTI Imaging System. For each concentration tested, we quantified the number of mCherry+ cells and data were normalized relatively to control ( $\mathrm{N} 1$ basal medium). 9cis retinoic acid (9cis-RA), a well-known compound promoting OPC differentiation was used a positive control. ${ }^{53}$

Our data revealed no statistically significant change in the number of mCherry+ cells after treatments with compounds $\mathbf{4 0}$ (Figure 5F). For compound 28, a significant increase of the 
number of mCherry+ oligodendrocytes was observed at $2 \mu \mathrm{M}$, while treatments at higher concentrations ranging from $10 \mu \mathrm{M}$ to $30 \mu \mathrm{M}$ lead to a complete loss of cells (Figure 5D), presumably due a cytotoxicity. In contrast, for compound 32 (Figure 5E) a significant increase of differentiation was observed with respect to basal control at concentrations of 6 $\mu \mathrm{M}(\mathrm{p} \leqslant 0.05)$ and $8 \mu \mathrm{M}(\mathrm{p} \leqslant 0.01$, Mann-Whitney test), and for compound 42 (Figure 5G) at 5 $\mu \mathrm{M}(\mathrm{p} \leqslant 0.05$, Mann-Whitney test). Thus, compounds 32 and $\mathbf{4 2}$ promote the differentiation of CG4 cells into mature oligodendrocytes. In view of their pharmacological and biological profiles, compounds $\mathbf{3 2}$ and $\mathbf{4 2}$ appear particularly suitable. Compounds $\mathbf{3 2}$ and $\mathbf{4 2}$ were also evaluated on primary cultures of rat OPCs (Figure 6). In this model, the differentiation rate was measured by the quantification of the number of MBP-expressing oligodendrocytes. MBP is a major constituent of myelin and is commonly used as a marker of mature oligodendrocytes. Compounds $\mathbf{3 2}$ and $\mathbf{4 2}$ promote the differentiation at concentrations of 8 $\mu \mathrm{M}$ and $5 \mu \mathrm{M}$, respectively. Overall, these findings support the pro-myelinating potential of para-aminobenzyl-hit derivatives. 
A
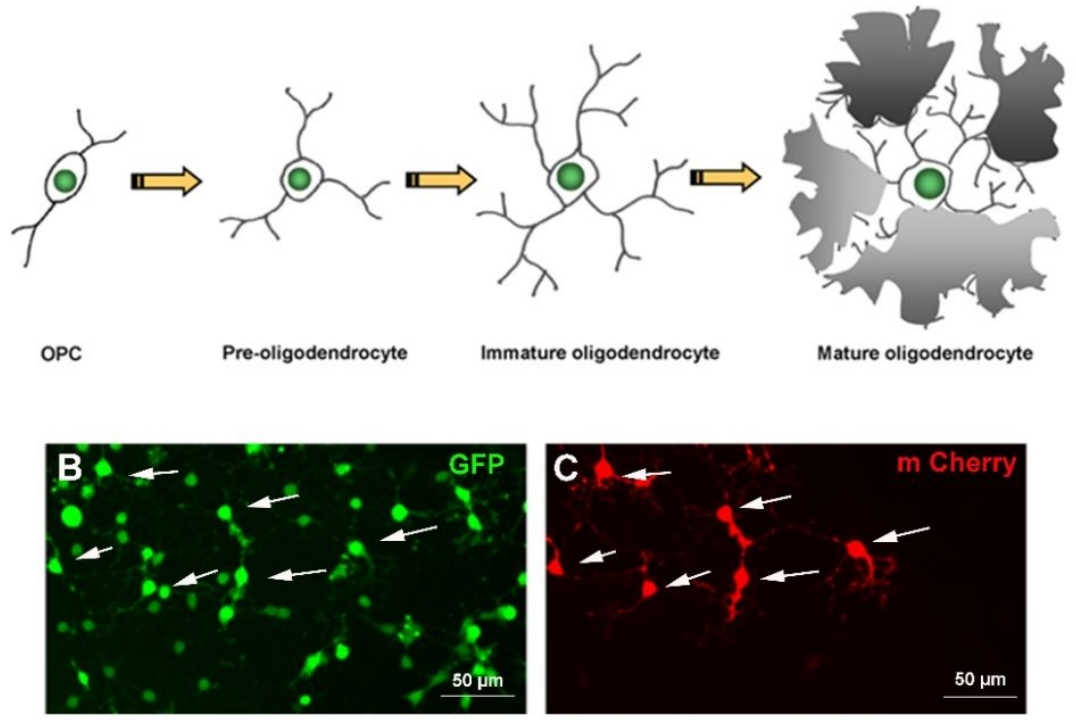

compound 28
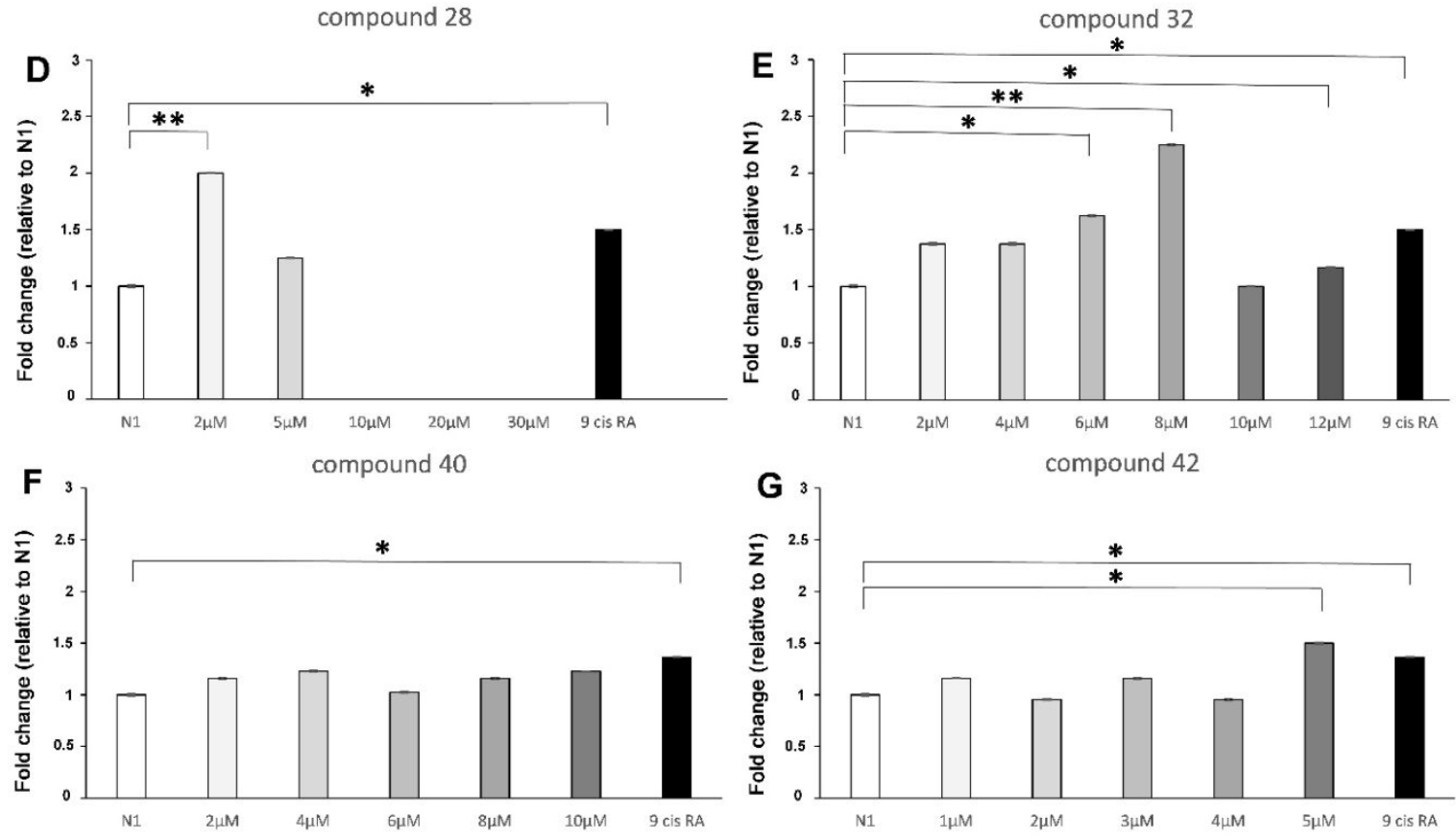

Figure 5: KLK6 inhibitors promote oligodendrocyte differentiation on the CG4 mCherry/GFP cell line. Schematic representation of the different developmental stages of the CG4 cell line (A). Differentiation of the mCherry/GFP double fluorescent CG4 cell line, after 4 days of differentiation in basal medium (B-C). GFP fluorescence is shown in (B) and mCherry fluorescence in (C). Note that the differentiation of CG4 cells is not synchronous in these cultures and the expression of mCherry occurs specifically at the mature oligodendrocyte stage. Graphs of the fold change of the number of mCherry+ cells in N1 alone, $\mathrm{N} 1$ + compound $\mathbf{2 8}(\mathrm{D}), \mathrm{N} 1$ + compound $\mathbf{3 2}$ (E), N1 + compound $\mathbf{4 0}(\mathrm{F})$ or $\mathrm{N} 1+$ compound $\mathbf{4 2}(\mathrm{G})$, after 4 days of differentiation. The treatment with KLK6 inhibitors $\mathbf{3 2}$ and $\mathbf{4 2}$ induces a significant increase of CG4 cell differentiation at $8 \mu \mathrm{M}$ and $5 \mu \mathrm{M}$ respectively, relative to the $\mathrm{N} 1$ basal medium. Note that CG4 cells treated with compound 28 at $2 \mu \mathrm{M}$ lead to a significant increase of the number of mCherry+ oligodendrocytes. However, at higher concentrations with this compound (ranging from 10 to $30 \mu \mathrm{M}$ ), cells were lost presumably due to a cytotoxicity. Wilcoxon - Mann Whitney test: ${ }^{*} p \leqslant 0.05$, ${ }^{* *} p \leqslant 0.01$. 9 cis retinoic acid (9cis-RA, $\left.1 \mu \mathrm{M}\right)$ was used as a positive control. Scale bar (B, C): $50 \mu \mathrm{m}$. 

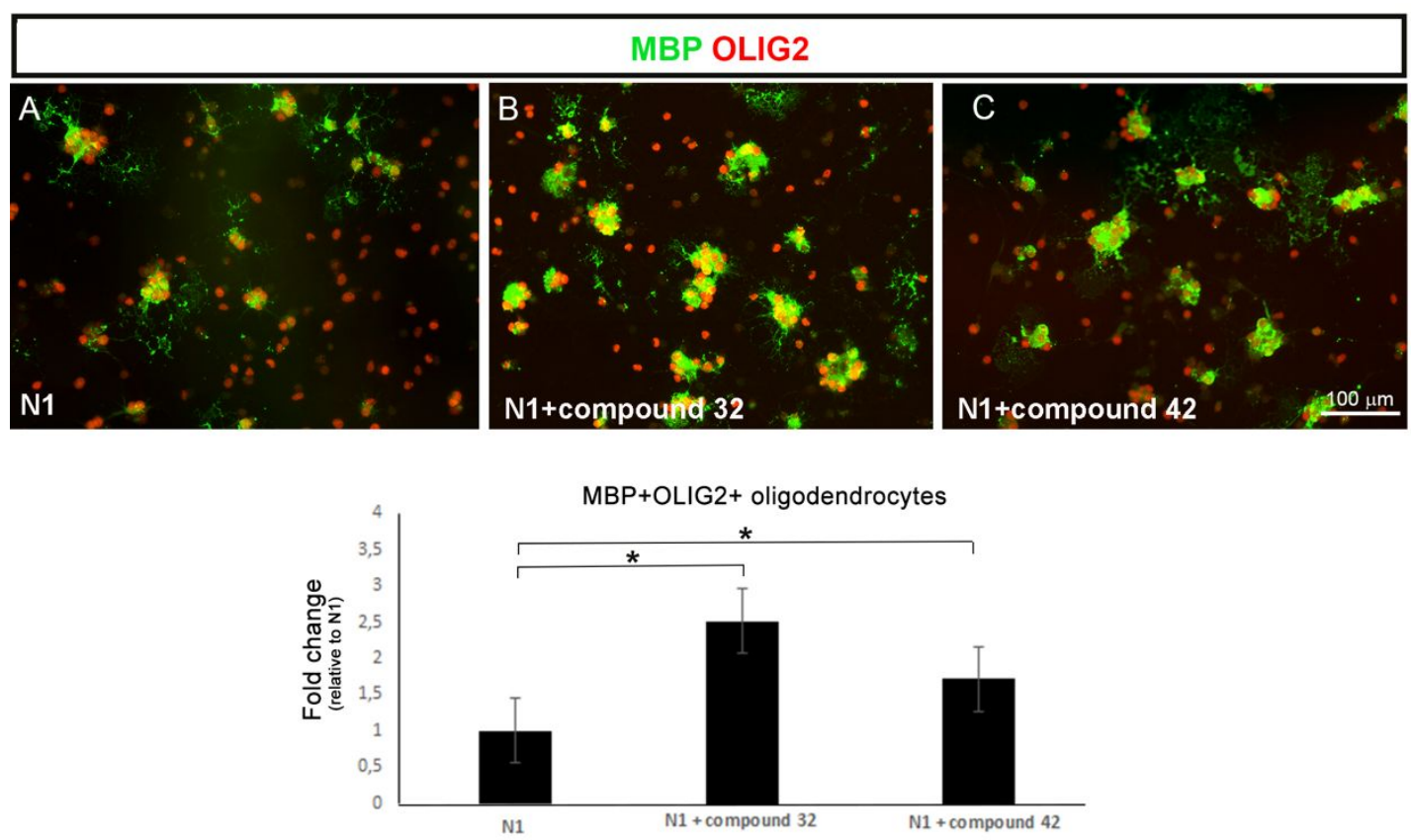

Figure 6: KLK6 inhibitors promote oligodendrocyte differentiation of primary OPC cultures. Primary OPC cultures, stained for MBP (green) and Olig2 (red), after 4 days of differentiation in basal medium $(\mathrm{A})$, in the presence of compound $42(\mathrm{~B}, 5 \mu \mathrm{M})$ or compound $32(\mathrm{C}, 8 \mu \mathrm{M})$. The treatment with KLK6 inhibitors induces a significant increase of $\mathrm{MBP}+$ oligodendrocytes with respect to control. $N=3$ independent experiments; Wilcoxon - Mann Whitney test: $\left.{ }^{*} p \leqslant 0.05\right)$. Scale bar (A, B, C): $100 \mu \mathrm{m}$.

\section{Anti-inflammatory properties of hit compounds}

In MS, chronic activation of microglia may contribute to neurodegeneration and neuroinflammation. ${ }^{35}$ Thus, we also examined the impact of hit compounds $\mathbf{3 2}$ and $\mathbf{4 2}$ on microglial activation and pro-inflammatory cytokines. These experiments were carried in primary microglial cells isolated from newborn rat brain. ${ }^{36}$ Effects of selected compounds on microglia were analyzed after treatment with lipopolysaccharide (LPS, $10 \mathrm{ng} / \mathrm{ml}$ ) alone or in presence of different concentrations framing $I C_{50}$ values of compounds 32 and $\mathbf{4 2}$, using dexamethasone as positive control (Figure 7). Using quantitative RT-qPCR of pro- and antiinflammatory cytokine gene expression, we showed that compound $\mathbf{4 2}$ significantly lowered the expression of TNF $\alpha$ and IL1 $\beta$ pro-inflammatory cytokines while compound $\mathbf{3 2}$ had no 
effect. This result illustrates potential distinct dual therapeutical effects and/or mechanism of action for these hit compounds.

[32]

A

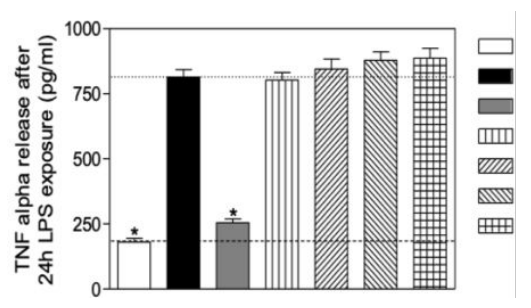

C
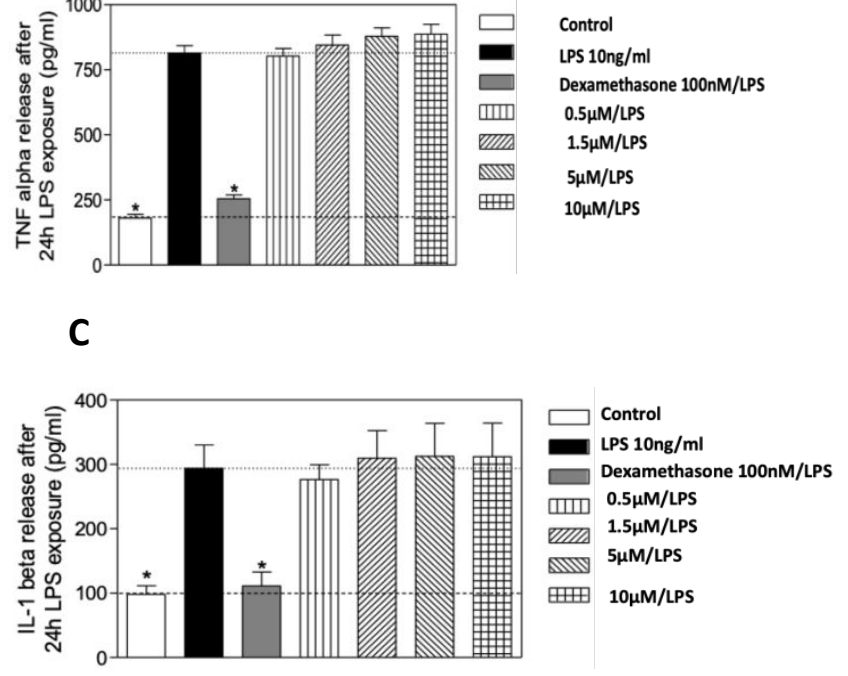

[42]

B

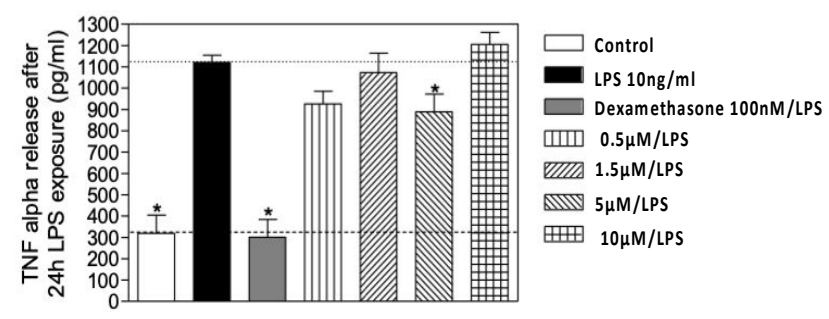

D

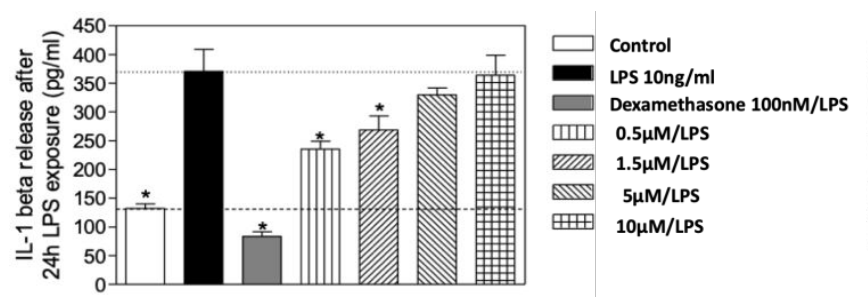

Figure 7: Anti-inflammatory potential of KLK6 inhibitors on a primary culture of microglia. Changes in TNF- $\alpha$ (A-B) and IL-1 $\beta$ (C-D) secretions after 24 hours of LPS exposure $\left(10 \mathrm{ng} . \mathrm{mL}^{-1}\right)$ and treatment by either inhibitor 32 (left) or $\mathbf{4 2}$ (right) in the concentration range [0,5 $\mu \mathrm{M}-10 \mu \mathrm{M}]$. Cytokine secretion was measured by ELISA assay. The treatment with inhibitor $\mathbf{4 2}$ induces a significant decrease of TNF $\alpha$ and IL1- $\beta$ secretions. Control: No treatment. Dexamethasone (100 nM): positive control $(n=3)$. (graph, * $\mathrm{p} \leq 0.05$ )

\section{Molecular docking modelling to study structural basis of the inhibition}

In silico analyzes using molecular docking with the AutoDock Vina software highlighted some characteristic structural bases on the inhibition of hit compounds 42 and 32 (Figure 8A).

Figures $\mathbf{8 B}$ and $\mathbf{8 C}$ illustrates their positioning for the best docking poses. Overall, the orientation of both compounds within the active site is identical with the benzylamine group pointing to the S1 pocket and the phenol/naphthol groups to the catalytic triad. Inhibitors 32 (Figure 8B) and 42 (Figure 8A) share several polar contacts with some active site residues, namely $\mathrm{H} 57$ and S195. In particular, the NH of the amide bond of compound $\mathbf{3 2}$ establishes a 
direct H-bond with the catalytic S195. We do not exclude a certain flexibility in this region, given the obtained results, which could allow the $\mathrm{NH}$ of the amide bond of compound $\mathbf{4 2}$ to behave similarly, this behavior may in part explain the non-competitive mechanism underlined by Dixon plots. The $\mathrm{OH}$ hydroxyl group of phenols or naphthols could also contribute to a polar bond with Q192 side chain as well as the NH backbone of G193. Finally, the primary amine shows strong polar contact in both cases with D189 and S190 side chains and with W215 backbone. The visual inspection of other docking poses with lower scores informed us about the certain degree of freedom of the benzylamine moiety inside the S1 pocket, the benzyl group having enough space to slightly rotate around its axis, even suggested by the two best poses of compounds 32 and $\mathbf{4 2}$. These poses are quite compatible with their mechanism of inhibition. 
A
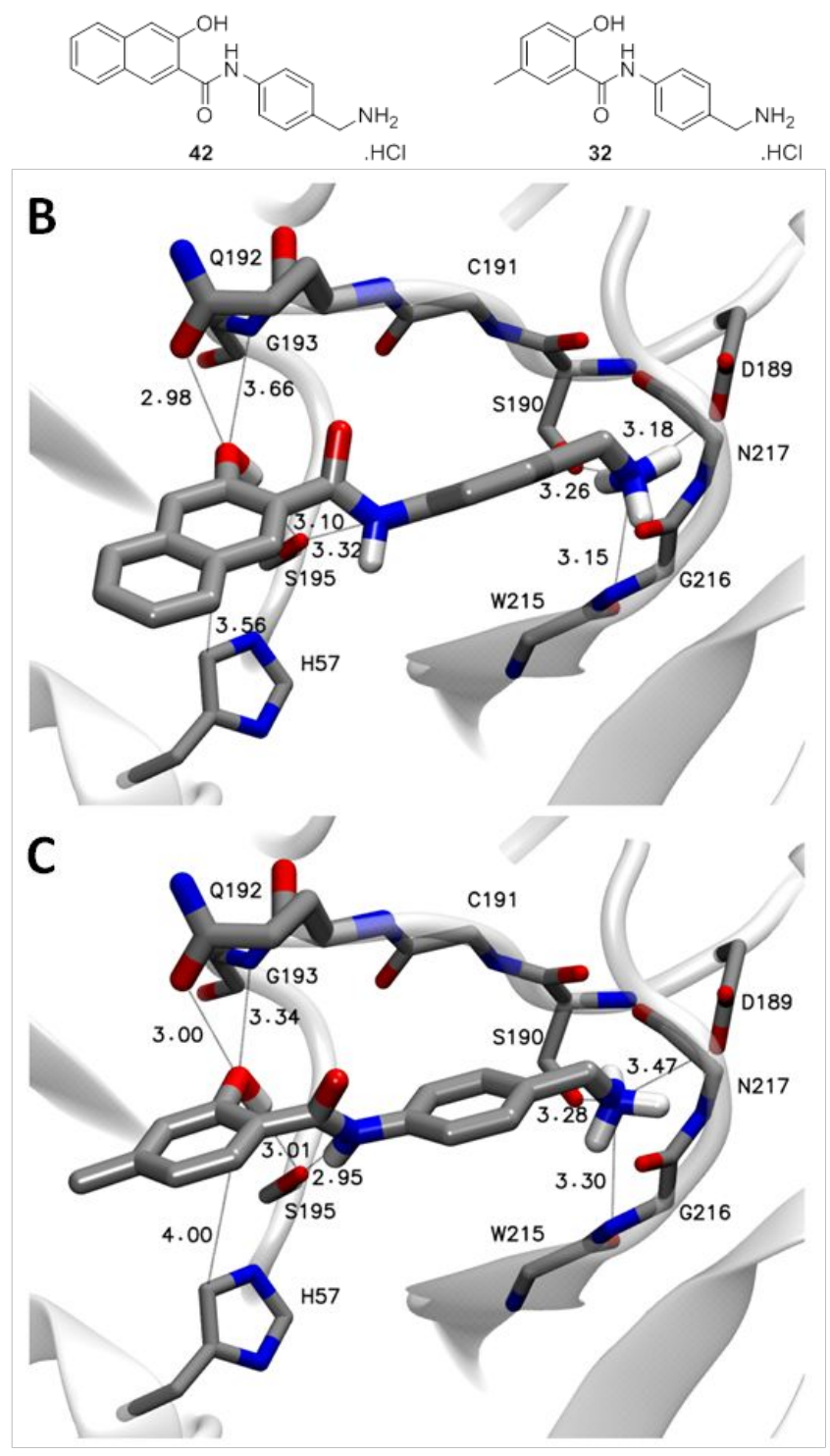

Figure 8: Structure of lead compounds 42 and 32 (A) and pose predictions by molecular docking of 42 (B) and 32 (C) in KLK6. Most relevant interactions were depicted by dashed lines together with distances in Angström. Compounds as well as residues of the proteins mainly involved in ligand interactions are shown in licorice while the full proteins are shown in transparent-white cartoon. The color code for the atoms is as follows: Carbon in grey, Oxygen in red, Nitrogen in blue and Hydrogen in white. The side chains which make no contact with $\mathbf{4 2}$ and 32, as well as hydrogens of the protein and non-polar hydrogens of $\mathbf{4 2}$ and $\mathbf{3 2}$ were not represented for clarity. 


\section{Pharmacological profile and evaluation of drug-like properties}

To gain more insights on the drug-like potential of the two selected hit compounds, different evaluations were performed to assess their: i) their putative effect of on coagulation; iii) their cross-reactivity toward key pharmacological targets using the SafetyScreen44 ${ }^{\mathrm{TM}}$ Panel from Eurofins 37 ; iv) some ADME-Tox properties: solution properties (aqueous solubility in simulated fluids and plasma protein binding), in vitro absorption (Caco2 cell line); in vitro metabolism (intrinsic clearance using human liver microsomes). More relevant parameters are summarized in Supplementary Data, Table S2. Altogether, these evaluations demonstrated that hit compounds $\mathbf{3 2}$ and $\mathbf{4 2}$ bear a very favorable pharmacological profile. They were shown to have no toxicity on coagulation after incubation with human blood (neither the activated partial thromboplastin time nor the prothrombin ratio were modified) and to possess acceptable aqueous solubility (> $150 \mu \mathrm{M}$, except for 42 at $\mathrm{pH} \geq 7.4$ ), permeability (> 90\%) and clearance properties (half-life $>120 \mathrm{~min}$ ) when compared to reference substances. Interestingly, among the 44 screened targets both receptors and enzymes, very few were inhibited by our lead compounds. No activity at ion channels (including hERG) was detected meaning weak toxicity. The only significant detected off targets were of interest both for CNS diseases $\left(5-\mathrm{HT}_{2 \mathrm{~A}} / 2 \mathrm{~B}\right.$ serotonin receptors) or inflammation (COX2). ${ }^{38}$ Hence, the selected compounds display favorable drug-like properties and constitute thus excellent starting point to derive drugs for regenerative therapy of MS and relateddiseases associated with a deregulation of KLK6 and proximal proteolytic network. 


\section{Conclusion}

Current MS therapeutics are mainly immuno- modulatory, having very few effect on neuroregeneration of damaged CNS tissue; they are thus primarily effective at the acute stage of disease, but much less so at the chronic stage. An MS therapy that has both immunomodulatory and neuro- regenerative effects would be highly beneficial. Novel targets aiming to promote such therapeutic strategies are thus of great interest. ${ }^{8}$ KLK6 and its proximal proteolytic network may constitute a new opportunity to develop new therapeutics or molecular tools for MS physiopathology. A series of para-aminobenzyl derivatives incorporating a phenol or a naphthol group was thus designed, synthesized and studied for their properties to inhibit KLK6 activity and proteases that may be involved into the KLK6's pathological network in MS, namely inhibitions of both KLK1 and plasmin may be interesting in a polypharmacological perspective.

Several designed low molecular weight inhibitors are low-micromolar potency and reversible towards KLK6. In the phenol series, introduction of an alkyl group at the C4 position led to more potent compounds (32 and $\mathbf{3 7}$ ), whereas in the naphthol series, the best activity was obtained with the 1- and 3-naphthol derivatives (40 and 42). Interestingly, these hit compounds were selective of KLK6 and its associated network over a large set of CNS concurrent proteases, and devoid of cytotoxic effects on primary cultures of mouse cortical and striatal neurons and oligodendrocytes. Most importantly, we show for the first time that synthetic inhibitors of KLK6 and proximal proteolytic network, a key actor of MS physiopathology, are able to promote the differentiation of OPCs into mature oligodendrocytes in vitro, which is as far as we know the first report of such properties. Indeed, the presence of oligodendrocyte progenitors (OPCS) in the adult CNS, which are able to migrate and regenerate remyelinating oligodendrocytes in demyelinating lesions, represent 
the main cellular target for the development of pharmacological strategy aiming to promote remyelination. In line with this idea, compounds $\mathbf{3 2}$ and $\mathbf{4 2}$ were also tested for their potential effect on neuroinflammation using primary cultures of microglia. Compound $\mathbf{4 2}$ decreased significantly the expression of pro-inflammatory cytokines. Hence, compound $\mathbf{4 2}$ in contrast to compound $\mathbf{3 2}$ appears to be a good candidate as a first-in-class KLK6 inhibitor bearing both remyelinating and anti-inflammatory potentials. There is a growing interest to decipher mechanisms regulating OPC differentiation for the identification of novel specific pharmacological targets for remyelination-enhancing therapy. ${ }^{34}$ In another hand, there also a growing interest for pro-differenciating compounds selected first through screening campaigns and more recently using rational design as illustrated in up-to-date reports. Namely, spiroindolines were shown as novel inducers of OPC differenciation. ${ }^{39}$ Recently, benzothiazoles LRRK2 inhibitors were shown to promote OPC proliferation and differenciation through $\mathrm{Wnt} / \beta$-catenin signaling pathway. ${ }^{40}$ Moreover, modified flavonoids were reported as selective inhibitors of hyaluronidase activity and could promote OPC maturation, making them excellent candidates to accelerate myelination or promote remyelination following perinatal and adult CNS insults. ${ }^{41}$ Thus, in view of their pharmacological and biological properties, para-aminobenzylamine derivatives $\mathbf{3 2}$ and $\mathbf{4 2}$ appear particularly valuable starting points for the development of original pharmacological strategies aiming to promote remyelination in demyelinating diseases, such as MS. 


\section{Experimental section}

All reagents were analytical grade. Distilled water was filtered and deionized through a Millipore water purification system.

\section{Chemistry Materials and General Procedures}

Commercially available reagents and solvents were used without further purification. Reactions were monitored by an analytical Waters Alliance 2690 HPLC instrument, equipped with a photodiode array and an analytical Chromolith Speed Rod RP-C18 185 Pm column (50 $x 4.6 \mathrm{~mm}, 5 \mathrm{~mm}$ ), at a flow rate of $3.0 \mathrm{~mL} / \mathrm{min}$, and gradients of $100 / 0$ to $0 / 100$ eluents $A / B$ for 5 min (eluent $A=\mathrm{H}_{2} \mathrm{O} / 0.1 \%$ TFA and $\mathrm{B}=\mathrm{CH}_{3} \mathrm{CN} / 0.1 \%$ TFA). Detection was performed at $214 \mathrm{~nm} .{ }^{1} \mathrm{H}$ and ${ }^{13} \mathrm{C}$ NMR spectra were recorded on Bruker spectrometers ( 300 or $400 \mathrm{MHz}$ ) at room temperature in deuterated solvents. Chemical shifts $(\delta)$ are expressed in parts per million (ppm), relative to the resonance of $\mathrm{CDCl}_{3}=7.26 \mathrm{ppm}$ for ${ }^{1} \mathrm{H}\left(77.16 \mathrm{ppm}\right.$ for $\left.{ }^{13} \mathrm{C}\right), \mathrm{CD}_{3} \mathrm{OD}$ $=3.31 \mathrm{ppm}$ for ${ }^{1} \mathrm{H}\left(49.00 \mathrm{ppm}\right.$ for $\left.{ }^{13} \mathrm{C}\right)$ or $\mathrm{DMSO} \mathrm{d}_{6}=2.50 \mathrm{ppm}$ for ${ }^{1} \mathrm{H}\left(39.52 \mathrm{ppm}\right.$ for $\left.{ }^{13} \mathrm{C}\right)$. The following abbreviations were used: s (singlet), $d$ (doublet), t (triplet), q (quartet), $m$ (multiplet), bs (broad singlet). Analytical thin-layer chromatography (TLC) was carried out on aluminum plates covered with $0.2 \mathrm{~mm}$ of silica and column chromatography was performed on silica gel 60 (70-230 mesh).

The LC/MS system consisted of a Waters Alliance 2695 HPLC, coupled to a Micromass (Manchester, UK) ZQ spectrometer (positive electrospray ionization mode, ESI+). All the analyses were carried out using a Merck Chromolith Speed rod C18, 25 × $4.6 \mathrm{~mm}$ reversedphase column. A flow rate of $3 \mathrm{~mL} / \mathrm{min}$ and a gradient of (0-100) \% B over 3 min (or over 15 min) were used. Eluent $\mathrm{A}$ : water/0.1\% $\mathrm{HCO}_{2} \mathrm{H}$; eluent $\mathrm{B}$ : acetonitrile/0.1\% $\mathrm{HCO}_{2} \mathrm{H}$. Retention 
times (RT) are given in minutes. Nitrogen was used for both the nebulizing and drying gas. The data were obtained in a scan mode ranging from 100 to $1000 \mathrm{~m} / \mathrm{z}$ in $0.1 \mathrm{~s}$ intervals; 10 scans were summed up to get the final spectrum. High-resolution mass spectrometry analyses were performed with a Waters Synapt G2-S time-of-flight mass spectrometer fitted with an electrospray ionisation source. All measurements were performed in the positive ion mode. Melting points $(\mathrm{Mp})$ are uncorrected and were recorded on a Stuart capillary melting point apparatus SMP3. All compounds tested for biological activity showed $>95 \%$ purity, as assessed by RP-HPLC (Chromolith Speed Rod RP-C18 185 Pm column $50 \times 4.6$ mm, 5 um; flow rate: 5.0 $\mathrm{mL} / \mathrm{min}$; gradients from $100 / 0$ to $0 / 100$ eluents $A / B$ over 5 min, in which eluent $A=\mathrm{H}_{2} \mathrm{O} / 0.1 \%$ TFA and $\mathrm{B}=\mathrm{CH}_{3} \mathrm{CN} / 0.1 \%$ TFA; detection was done at $214 \mathrm{~nm}$ ).

Compound $\mathbf{2 6}$ was synthesized according to the procedure described by Darensburg et al. ${ }^{42}$ and its physical characteristics were in agreement with the published data. Carboxylic acids were commercially available or synthesized according to the procedures described in ESI.

\section{Synthesis of tert-butyl (4-nitrobenzyl) carbamate (1):}

To a solution of 4-nitrobenzylamine hydrochloride $(1 \mathrm{~g}, 5.3 \mathrm{mmol})$ in $10 \mathrm{~mL}$ of dichloromethane were added $480 \mu \mathrm{L}$ of triethylamine (348 mg, $3.44 \mathrm{mmol}, 1.3$ equiv.) and $790 \mu \mathrm{L}$ of tert-butyl dicarbonate $(751 \mathrm{mg}, 3.44 \mathrm{mmol}, 1.3$ equiv.). The solution was stirred at room temperature for 2 hours. Then was added 0.3 equiv. of aminomethyl polystyrene resin and the suspension was stirred for 1 hour. After filtration, the solution was washed with $1 \mathrm{M}$ aqueous potassium hydrogenosulfate solution $(2 \times 15 \mathrm{~mL})$ and with brine $(15 \mathrm{~mL})$. The organic layer was dried over $\mathrm{Na}_{2} \mathrm{SO}_{4}$, filtered and the solvent is evaporated in vacuo to offer compound 1 as a white solid $\left(\mathrm{m}=1.06 \mathrm{~g}, 80 \%\right.$ yield); $\mathrm{mp} 109-111^{\circ} \mathrm{C}$ (lit. $\left.109-110^{\circ} \mathrm{C}\right){ }^{43} ;{ }^{1} \mathrm{H} \mathrm{NMR}\left(\mathrm{CDCl}_{3}, 300\right.$ MHz): $\delta$ ppm $1.43(\mathrm{~s}, 9 \mathrm{H}), 4.37(\mathrm{~d}, 2 \mathrm{H}, J=6.2 \mathrm{~Hz}), 5.03(\mathrm{bs}, 1 \mathrm{H}), 7.41(\mathrm{~d}, 2 \mathrm{H}, J=8.8 \mathrm{~Hz}), 8.14(\mathrm{~d}$, 
$2 \mathrm{H}, J=8.8 \mathrm{~Hz}) ;{ }^{13} \mathrm{C} \mathrm{NMR}\left(\mathrm{CDCl}_{3}, 75 \mathrm{MHz}\right): \delta \mathrm{ppm} 27.5,44.2,85.3,123.9,127.9,146.9,147.4$, 156.0; HPLC, RT= 1.68 min.

\section{Synthesis of tert-butyl (4-aminobenzyl)carbamate (2):}

To a solution of compound 1 (1 g, $4.0 \mathrm{mmol}$ ) in $20 \mathrm{~mL}$ of ethyl acetate was added $10 \%$ palladium activated on charcoal ( $20 \mathrm{mg})$. The suspension was hydrogenated at atmospheric pressure for 4 hours at room temperature. The suspension was then filtered on celite and the filtrate was evaporated under reduce pressure to yield compound $\mathbf{2}$ as a pale orange solid, $\mathrm{m}$ $=880 \mathrm{mg}$, quantitative yield. $\mathrm{Mp} 72-75^{\circ} \mathrm{C}$ (lit. $\left.72-75^{\circ} \mathrm{C}\right){ }^{44} ;{ }^{1} \mathrm{H} \mathrm{NMR}\left(\mathrm{CDCl}_{3}, 300 \mathrm{MHz}\right): \delta \mathrm{ppm}$ $1.43(\mathrm{~s}, 9 \mathrm{H}), 3.60$ (bs, 2H), $4.14(\mathrm{~d}, 2 \mathrm{H}, J=5.6 \mathrm{~Hz}$ ), $4.74(\mathrm{bs}, 1 \mathrm{H}), 6.60(\mathrm{~d}, 2 \mathrm{H}, J=8.4 \mathrm{~Hz}), 7.02$ (d, $2 \mathrm{H}, J=8.4 \mathrm{~Hz}) ;{ }^{13} \mathrm{C} \mathrm{NMR}\left(\mathrm{CDCl}_{3}, 75 \mathrm{MHz}\right): \delta \mathrm{ppm} 28.5,44.5,79.4,115.3,128.9,135.1,145.8$, 155.9; HPLC, RT= $0.93 \mathrm{~min} ; \mathrm{MS}(\mathrm{ESI}+): \mathrm{m} / \mathrm{z} 223.3[\mathrm{M}+\mathrm{H}]^{+}$.

\section{General procedure for the synthesis of compounds 3-28:}

To a solution of $100 \mathrm{mg}$ of compound $2(0.45 \mathrm{mmol})$ in $2.5 \mathrm{~mL}$ of THF was added 1 equiv. of the appropriate carboxylic acid derivative $(0.45 \mathrm{mmol})$ and $103 \mathrm{mg}$ of $\mathrm{N}$-(3dimethylaminopropyl)- $N^{\prime}$-ethylcarbodiimide hydrochloride (1 equiv., $0.45 \mathrm{mmol}$ ). The solution was stirred at reflux for 12 hours. After cooling to room temperature, the solution was evaporated to dryness. The crude product was dissolved in $20 \mathrm{~mL}$ of ethyl acetate and the solution was washed with $1 \mathrm{~N}$ hydrochloric acid solution $(3 \times 20 \mathrm{~mL})$ and then by $10 \%$ aqueous sodium carbonate solution. The organic layer was dried over $\mathrm{Na}_{2} \mathrm{SO}_{4}$, filtered and the solvent is evaporated in vacuo. The resulting crude mixture was washed with $\mathrm{Et}_{2} \mathrm{O}$ for compounds 4, 10 and 23. Compounds $13,16-21$ and 24 were used without further purification in the subsequent step. Other compounds were purified by chromatography on silica gel. 
Tert-butyl (4-(5-tert-butyl-2-hydroxybenzoyl))aminobenzylcarbamate (3). Elution : DCM/EtOH 98.5/1.5 v/v; White solid ( $\mathrm{m}=58 \mathrm{mg}, 32 \%$ yield); $\mathrm{mp}: 177-178^{\circ} \mathrm{C} ;{ }^{1} \mathrm{H} \mathrm{NMR}\left(\mathrm{CDCl}_{3}, 300 \mathrm{MHz}\right): \delta$ ppm $1.31(\mathrm{~s}, 9 \mathrm{H}), 1.44(\mathrm{~s}, 9 \mathrm{H}), 4.26(\mathrm{~d}, 2 \mathrm{H}, J=5.9 \mathrm{~Hz}), 4.89(\mathrm{bs}, 1 \mathrm{H}), 6.93(\mathrm{~d}, 1 \mathrm{H}, J=8.7 \mathrm{~Hz})$, $7.24(\mathrm{~m}, 2 \mathrm{H}), 7.48(\mathrm{~m}, 4 \mathrm{H}), 8.24$ (bs, $1 \mathrm{H}), 11.0(\mathrm{~s}, 1 \mathrm{H}) ;{ }^{13} \mathrm{C} \mathrm{NMR}\left(\mathrm{CDCl}_{3}, 75 \mathrm{MHz}\right): \delta \mathrm{ppm} 28.6$, $31.4,31.6,44.4,79.9,114.4,118.4,121.9,122.1,128.2,132.3,136.0,136.1,142.0,156.1$, 159.3, 168.7; HPLC, RT= 2.10 min; MS (ESI+): m/z $399.3[\mathrm{M}+\mathrm{H}]^{+}$; HRMS calcd for $\mathrm{C}_{23} \mathrm{H}_{31} \mathrm{~N}_{2} \mathrm{O}_{4}$ 399.2278, found 399.2272.

Tert-butyl (4-(2-hydroxybenzoyl))aminobenzylcarbamate (4). White solid (m= $113 \mathrm{mg}, 73 \%$ yield); mp: $107-171^{\circ} \mathrm{C} ;{ }^{1} \mathrm{H} \mathrm{NMR}$ (DMSO d, $300 \mathrm{MHz}$ ): $\delta$ ppm 1.40 (s, 9H), 3.30 (bs, $1 \mathrm{H}$ ), 4.10 (d, $2 \mathrm{H}, J=6.0 \mathrm{~Hz}), 6.96(\mathrm{~m}, 2 \mathrm{H}), 7.23(\mathrm{~d}, 2 \mathrm{H}, J=8.4 \mathrm{~Hz}), 7.33(\mathrm{bt}, 1 \mathrm{H}, J=6.0 \mathrm{~Hz}), 7.44(\mathrm{td}, 1 \mathrm{H}, J=$ $8.5 \mathrm{~Hz}, 1.6 \mathrm{~Hz}), 7.62(\mathrm{~d}, 2 \mathrm{H}, J=8.4 \mathrm{~Hz}), 7.97(\mathrm{dd}, 1 \mathrm{H}, J=8.5 \mathrm{~Hz}, 1.6 \mathrm{~Hz}), 10.35(\mathrm{~s}, 1 \mathrm{H}) ;{ }^{13} \mathrm{C} N M R$ (DMSO $d_{6}, 75 \mathrm{MHz}$ ): $\delta$ ppm 28.2, 43.0, 77.7, 117.2, 118.9, 120.9, 127.3, 128.9, 133.6, 136.0, 136.6, 155.7, 158.6, 166.5; HPLC, RT= $1.78 \mathrm{~min} ; \mathrm{MS}(\mathrm{ESI}+): \mathrm{m} / \mathrm{z} 365.0[\mathrm{M}+\mathrm{Na}]^{+}, 287.1[\mathrm{M}+\mathrm{H}-$ tBu] $]^{+}$; HRMS calcd for $\mathrm{C}_{19} \mathrm{H}_{23} \mathrm{~N}_{2} \mathrm{O}_{4} 343.1652$, found 343.1655 .

Tert-butyl (4-(3-methyl-2-hydroxybenzoyl))aminobenzylcarbamate (5). Elution: DCM/EtOH 92/2 v/v. Light yellow solid ( $m=125 \mathrm{mg}, 78 \%$ yield); $\mathrm{mp}: 166.2-166.9^{\circ} \mathrm{C} ;{ }^{1} \mathrm{H} \mathrm{NMR}\left(\mathrm{CDCl}_{3}, 400\right.$ MHz): $\delta$ ppm 1.45 (s, 9H), $2.27(\mathrm{~s}, 3 \mathrm{H}), 4.28(\mathrm{~d}, 2 \mathrm{H}, J=5.7 \mathrm{~Hz}), 4.85(\mathrm{bs}, 1 \mathrm{H}), 6.79(\mathrm{t}, 1 \mathrm{H}, J=7.7$ $\mathrm{Hz}), 7.28(\mathrm{~m}, 3 \mathrm{H}), 7.37(\mathrm{~d}, 1 \mathrm{H}, J=7.7 \mathrm{~Hz}), 7.50(\mathrm{~d}, 2 \mathrm{H}, J=8.4 \mathrm{~Hz}), 8.00(\mathrm{bs}, 1 \mathrm{H}), 12.3(\mathrm{~s}, 1 \mathrm{H}) ;{ }^{13} \mathrm{C}$ $\operatorname{NMR}\left(\mathrm{CDCl}_{3}, 100 \mathrm{MHz}\right): \delta$ ppm 16.0, 28.6, 44.4, 79.9, 113.8, 118.4, 121.7, 123.1, 128.3, 128.4, 135.6, 136.1, 136.2, 156.1, 160.5, 169.1; HPLC, RT= $2.01 \mathrm{~min} ; \mathrm{MS}(\mathrm{ESI}+): \mathrm{m} / \mathrm{z} 379.2[\mathrm{M}+\mathrm{Na}]^{+}$, 301.2 [M+H-tBu] ${ }^{+}$; HRMS calcd for $\mathrm{C}_{20} \mathrm{H}_{25} \mathrm{~N}_{2} \mathrm{O}_{4} 357.1809$, found 357.1811. 
Tert-butyl (4-(4-methyl-2-hydroxybenzoyl))aminobenzylcarbamate (6). Elution: $n$-Hex/AcOEt 2/1 v/v. Light yellow solid ( $\mathrm{m}=131 \mathrm{mg}, 82 \%$ yield); $\mathrm{mp}: 191.8-192.8^{\circ} \mathrm{C} ;{ }^{1} \mathrm{H} \mathrm{NMR}\left(\mathrm{CDCl}_{3}, 400\right.$ MHz): $\delta$ ppm $1.45(\mathrm{~s}, 9 \mathrm{H}), 2.33(\mathrm{~s}, 3 \mathrm{H}), 4.28(\mathrm{~d}, 2 \mathrm{H}, J=5.5 \mathrm{~Hz}), 4.84(\mathrm{bs}, 1 \mathrm{H}), 6.70(\mathrm{dd}, 1 \mathrm{H}, J=$ $8.1 \mathrm{~Hz}, 1.1 \mathrm{~Hz}), 6.82(\mathrm{~d}, 1 \mathrm{H}, J=1.1 \mathrm{~Hz}), 7.27(\mathrm{~d}, 2 \mathrm{H}, J=8.4 \mathrm{~Hz}), 7.39(\mathrm{~d}, 1 \mathrm{H}, J=8.1 \mathrm{~Hz}), 7.50$ (d, $2 \mathrm{H}, J=8.4 \mathrm{~Hz}$ ), $7.93(\mathrm{bs}, 1 \mathrm{H}), 11.94(\mathrm{~s}, 1 \mathrm{H}) ;{ }^{13} \mathrm{C} \mathrm{NMR}\left(\mathrm{CDCl}_{3}, 100 \mathrm{MHz}\right): \delta \mathrm{ppm}$ 21.9, 28.6, 44.4, 79.9, 112.1, 119.3, 120.3, 121.6, 125.5, 128.4, 136.1, 136.2, 146.1, 156.1, 162.1, 168.6; HPLC, $\mathrm{RT}=1.90 \mathrm{~min} ; \mathrm{MS}(\mathrm{ESI}+): \mathrm{m} / \mathrm{z} 357.2[\mathrm{M}+\mathrm{H}]^{+}, 379.1[\mathrm{M}+\mathrm{Na}]^{+}, 301.2[\mathrm{M}+\mathrm{H}-\mathrm{tBu}]^{+} ; \mathrm{HRMS}$ calcd for $\mathrm{C}_{20} \mathrm{H}_{25} \mathrm{~N}_{2} \mathrm{O}_{4}$ 357.1809, found 357.1809.

Tert-butyl (4-(5-methyl-2-hydroxybenzoyl))aminobenzylcarbamate (7). Elution: $n$-Hex/AcOEt $2 / 1 \mathrm{v} / \mathrm{v}$. Light yellow solid ( $\mathrm{m}=68 \mathrm{mg}, 42 \%$ yield); $\mathrm{mp}: 174.5-175.5^{\circ} \mathrm{C} ;{ }^{1} \mathrm{H} \mathrm{NMR}\left(\mathrm{CDCl}_{3}, 400\right.$ MHz): $\delta$ ppm $1.45(\mathrm{~s}, 9 \mathrm{H}), 2.32(\mathrm{~s}, 3 \mathrm{H}), 4.28(\mathrm{~d}, 2 \mathrm{H}, J=5.4 \mathrm{~Hz}), 4.84(\mathrm{bs}, 1 \mathrm{H}), 6.91(\mathrm{~d}, 1 \mathrm{H}, J=8.4$ $\mathrm{Hz}), 7.22-7.29(\mathrm{~m}, 4 \mathrm{H}), 7.52(\mathrm{~d}, 2 \mathrm{H}, \mathrm{J}=8.4 \mathrm{~Hz}), 7.96(\mathrm{bs}, 1 \mathrm{H}), 11.71(\mathrm{~s}, 1 \mathrm{H}) ;{ }^{13} \mathrm{C} \mathrm{NMR}\left(\mathrm{CDCl}_{3}, 100\right.$ MHz): $\delta$ ppm 20.8, 28.6, 44.4, 79.9, 114.4, 115.5, 118.8, 121.6, 123.3, 125.7, 128.4, 135.8, 136.1, 156.1, 159.8, 168.6; HPLC, RT= $1.90 \mathrm{~min} ; \mathrm{MS}(\mathrm{ESI}+): \mathrm{m} / \mathrm{z} 379.2[\mathrm{M}+\mathrm{Na}]^{+}, 301.2[\mathrm{M}+\mathrm{H}-$ tBu] $]^{+}$; HRMS calcd for $\mathrm{C}_{20} \mathrm{H}_{25} \mathrm{~N}_{2} \mathrm{O}_{4} 357.1809$, found 357.1810.

Tert-butyl (4-(6-methyl-2-hydroxybenzoyl))aminobenzylcarbamate (8). Elution: $n$-Hex/AcOEt $2 / 1 \mathrm{v} / \mathrm{v}$. Light yellow solid ( $\mathrm{m}=33 \mathrm{mg}, 21 \%$ yield); $\mathrm{mp}: 149.0-150.0^{\circ} \mathrm{C} ;{ }^{1} \mathrm{H} \mathrm{NMR}\left(\mathrm{CDCl}_{3}, 300\right.$ MHz): $\delta$ ppm $1.46(\mathrm{~s}, 9 \mathrm{H}), 2.60(\mathrm{~s}, 3 \mathrm{H}), 4.28(\mathrm{~d}, 2 \mathrm{H}, J=5.4 \mathrm{~Hz}), 4.91(\mathrm{bs}, 1 \mathrm{H}), 6.76(\mathrm{~d}, 1 \mathrm{H}, J=7.5$ $\mathrm{Hz}), 6.84(\mathrm{~d}, 1 \mathrm{H}, J=8.2 \mathrm{~Hz}), 7.23(\mathrm{dd}, 1 \mathrm{H}, J=8.2 \mathrm{~Hz}, 7.5 \mathrm{~Hz}), 7.27(\mathrm{~d}, 2 \mathrm{H}, J=8.0 \mathrm{~Hz}$ ), $7.52(\mathrm{~d}$, $2 \mathrm{H}, J=8.0 \mathrm{~Hz}), 7.72(\mathrm{~s}, 1 \mathrm{H}), 9.85$ (bs, $1 \mathrm{H}) ;{ }^{13} \mathrm{C} \mathrm{NMR}\left(\mathrm{CDCl}_{3}, 75 \mathrm{MHz}\right): \delta \mathrm{ppm} 22.1,28.5,44.3$, 78.3, 115.7, 119.0, 121.0, 123.1, 128.4, 132.5, 135.5, 136.1, 136.2, 156.1, 159.2, 168.4; HPLC, $\mathrm{RT}=1.60 \mathrm{~min} ; \mathrm{MS}(\mathrm{ESI}+): \mathrm{m} / \mathrm{z} 379.1[\mathrm{M}+\mathrm{Na}]^{+}, 301.2[\mathrm{M}+\mathrm{H}-\mathrm{tBu}]^{+} ; \mathrm{HRMS}$ calcd for $\mathrm{C}_{20} \mathrm{H}_{25} \mathrm{~N}_{2} \mathrm{O}_{4}$ 357.1809 , found 357.1808 . 
Tert-butyl (4-(5-bromo-2-hydroxybenzoyl))aminobenzylcarbamate (9). Elution: $n$-Hex/AcOEt 4/1 v/v. White solid ( $m=24 \mathrm{mg}, 12 \%$ yield); $\mathrm{mp}:>300^{\circ} \mathrm{C}^{1} \mathrm{H}$ NMR (DMSO $d_{6}, 400 \mathrm{MHz}$ ): $\delta \mathrm{ppm}$ $1.93(\mathrm{~s}, 9 \mathrm{H}), 4.10(\mathrm{~d}, 2 \mathrm{H}, J=6.0 \mathrm{~Hz}), 6.95(\mathrm{~d}, 1 \mathrm{H}, J=8.8 \mathrm{~Hz}), 7.23(\mathrm{~d}, 2 \mathrm{H}, J=8.3 \mathrm{~Hz}), 7.37(\mathrm{t}, 1 \mathrm{H}$, $J=6.8 \mathrm{~Hz}), 7.57(\mathrm{dd}, 1 \mathrm{H}, J=8.8 \mathrm{~Hz}, 2.6 \mathrm{~Hz}), 7.62(\mathrm{~d}, 2 \mathrm{H}, J=8.3 \mathrm{~Hz}), 8.08(\mathrm{~d}, 1 \mathrm{H}, J=2.6 \mathrm{~Hz})$, 10.44 (s, 1H), 11.93 (bs, 1H); $\left.{ }^{13} \mathrm{C} \mathrm{NMR} \mathrm{(CDCl} 3,100 \mathrm{MHz}\right): \delta$ ppm 28.2, 43.0, 77.8, 110.0, 119.6, $119.9,120.8,127.3,131.1,135.8,136.2,136.5,155.8,157.6,164.9 ; \mathrm{HPLC}, \mathrm{RT}=2.00 \mathrm{~min} ; \mathrm{MS}$ $(\mathrm{ESI}+): \mathrm{m} / \mathrm{z} 443.0[\mathrm{M}+\mathrm{Na}]^{+}, 445.0[\mathrm{M}+2+\mathrm{Na}]^{+}, 367.0[\mathrm{M}+\mathrm{H}-\mathrm{tBu}]^{+}, 365.0[\mathrm{M}+\mathrm{H}+2-\mathrm{tBu}]^{+} ; \mathrm{HRMS}$ calcd for $\mathrm{C}_{19} \mathrm{H}_{21} \mathrm{BrN}_{2} \mathrm{NaO}_{4} 443.0577$, found 443.0575.

Tert-butyl (4-(5-methoxy-2-hydroxybenzoyl))aminobenzylcarbamate (10). White solid ( $m=75$ mg, 45\% yield); ${ }^{1} \mathrm{H}$ NMR (DMSO $\left.d_{6}, 300 \mathrm{MHz}\right): \delta$ ppm $1.39(\mathrm{~s}, 9 \mathrm{H}), 3.76(\mathrm{~s}, 3 \mathrm{H}), 4.10(\mathrm{~d}, 2 \mathrm{H}, J=$ $5.9 \mathrm{~Hz}$ ), $6.92(\mathrm{~d}, 1 \mathrm{H}, J=8.9 \mathrm{~Hz}$ ), $7.06(\mathrm{ddd}, 1 \mathrm{H}, J=9.0 \mathrm{~Hz}, 9.0 \mathrm{~Hz}, 3.0 \mathrm{~Hz}), 7.23(\mathrm{~d}, 2 \mathrm{H}, J=8.3$ $\mathrm{Hz}), 7.37(\mathrm{bt}, 1 \mathrm{H}, J=5.9 \mathrm{~Hz}), 7.50(\mathrm{~d}, 1 \mathrm{H}, J=3.0 \mathrm{~Hz}), 7.62(\mathrm{~d}, 2 \mathrm{H}, J=8.3 \mathrm{~Hz}), 10.90(\mathrm{~s}, 1 \mathrm{H}) ;{ }^{13} \mathrm{C}$ NMR (DMSO $d_{6}, 75 \mathrm{MHz}$ ): $\delta$ ppm 28.2, 43.0, 55.7, 77.8, 112.5, 117.3, 118.1, 120.6, 121.0, 127.4, 136.1, 136.6, 151.8, 152.3, 155.8, 166.0; ; HPLC, RT= 1.78 min; MS (ESI+): m/z 395.1 $[\mathrm{M}+\mathrm{Na}]^{+}, 373.1[\mathrm{M}+\mathrm{H}]^{+} ; 317.1[\mathrm{M}+\mathrm{H}-\mathrm{tBu}]^{+}$.

Tert-butyl (4-(4-isopropyl-2-hydroxybenzoyl))aminobenzylcarbamate (11). Elution: $n$ Hex/AcOEt 3/1 v/v. White solid ( $m=53 \mathrm{mg}, 31 \%$ yield); ${ }^{1} \mathrm{H} \mathrm{NMR}\left(\mathrm{CDCl}_{3}, 400 \mathrm{MHz}\right): \delta \mathrm{ppm} 1.60$ (d, $6 \mathrm{H}, J=6.7 \mathrm{~Hz}$ ), $1.83(\mathrm{~s}, 9 \mathrm{H}), 3.24$ (hept., $1 \mathrm{H}, J=6.7 \mathrm{~Hz}), 4.64(\mathrm{~d}, 2 \mathrm{H}, J=4.0 \mathrm{~Hz}$ ), 5.25 (bs, 1H), $7.12(\mathrm{~d}, 1 \mathrm{H}, J=7.1 \mathrm{~Hz}), 7.60(\mathrm{~d}, 2 \mathrm{H}, J=7.6 \mathrm{~Hz}), 7.86(\mathrm{~m}, 3 \mathrm{H}), 8.47(\mathrm{bs}, 1 \mathrm{H}), 12.30(\mathrm{bs}, 1 \mathrm{H})$; ${ }^{13} \mathrm{C} \mathrm{NMR}\left(\mathrm{CDCl}_{3}, 100 \mathrm{MHz}\right): \delta \mathrm{ppm} 23.7,28.6,34.4,44.4,79.9,112.5,116.5,117.9,121.7$, $125.8,128.3,136.0,136.2,156.2,156.9,162.1,168.6 ; \mathrm{HPLC}, \mathrm{RT}=2.09 \mathrm{~min} ; \mathrm{MS}(\mathrm{ESI}+): \mathrm{m} / \mathrm{z}$ $407.1[\mathrm{M}+\mathrm{Na}]^{+}, 385.2[\mathrm{M}+\mathrm{H}]^{+}$. 
Tert-butyl (4-(4-trifluoromethyl-2-hydroxybenzoyl))aminobenzylcarbamate (12). Elution DCM/EtOH 99/1 v/v; White solid ( $m=114 \mathrm{mg}, 62 \%$ yield); $\mathrm{mp}: 179.5-180.5^{\circ} \mathrm{C} ;{ }^{1} \mathrm{H}$ NMR $\left(\mathrm{CD}_{3} \mathrm{OD}\right.$, $400 \mathrm{MHz}): \delta$ ppm $1.46(\mathrm{~s}, 9 \mathrm{H}), 4.22(\mathrm{~s}, 2 \mathrm{H}), 4.76(\mathrm{bs}, 1 \mathrm{H}), 7.22(\mathrm{~m}, 2 \mathrm{H}), 7.29(\mathrm{~d}, 2 \mathrm{H}, J=8.4 \mathrm{~Hz})$, $7.63(\mathrm{~d}, 2 \mathrm{H}, J=8.4 \mathrm{~Hz}), 8.11(\mathrm{~d}, 1 \mathrm{H}, J=8.6 \mathrm{~Hz}) ;{ }^{13} \mathrm{C} \mathrm{NMR}\left(\mathrm{CD}_{3} \mathrm{OD}, 100 \mathrm{MHz}\right): \delta \mathrm{ppm} \mathrm{28.8,} \mathrm{44.6,}$ $80.2,115.2(\mathrm{~d}, J=3.7 \mathrm{~Hz}), 116.5(\mathrm{~d}, J=3.7 \mathrm{~Hz}), 122.0,122.5,126.3,128.7,131.2,135.8,137.8$, 158.6, 160.4, 165.2, $167.4 ; \mathrm{HPLC}, \mathrm{RT}=1.86 \mathrm{~min} ; \mathrm{MS}(\mathrm{ESI}+): \mathrm{m} / \mathrm{z} 433.0[\mathrm{M}+\mathrm{Na}]^{+}, 411.1[\mathrm{M}+\mathrm{H}]^{+}$, 355.0 [M+H-tBu] $]^{+}$; HRMS calcd for $\mathrm{C}_{20} \mathrm{H}_{22} \mathrm{~F}_{3} \mathrm{~N}_{2} \mathrm{O}_{4}$ 411.1526, found 411.1537.

Tert-butyl (4-(4-fluoro-2-hydroxybenzoyl))aminobenzylcarbamate (13). Elution DCM/EtOH 99/1 v/v; White solid ( $\mathrm{m}=37 \mathrm{mg}, 23 \%$ yield); $\mathrm{mp}: 155-5-156.5^{\circ} \mathrm{C} ;{ }^{1} \mathrm{H} \mathrm{NMR}\left(\mathrm{CD}_{3} \mathrm{OD}, 400 \mathrm{MHz}\right)$ : $\delta$ ppm $1.45(\mathrm{~s}, 9 \mathrm{H}), 4.21(\mathrm{~s}, 2 \mathrm{H}), 6.64-6.70(\mathrm{~m}, 2 \mathrm{H}), 7.26(\mathrm{~d}, 2 \mathrm{H}, J=8.4 \mathrm{~Hz}), 7.59(\mathrm{~d}, 2 \mathrm{H}, J=8.4$ $\mathrm{Hz}), 7.98(\mathrm{dd}, 1 \mathrm{H}, J=9.4 \mathrm{~Hz}, 8.4 \mathrm{~Hz}) ;{ }^{19} \mathrm{~F} \mathrm{NMR}\left(\mathrm{CD}_{3} \mathrm{OD}, 400 \mathrm{MHz}\right): \delta \mathrm{ppm}-107.1 ;{ }^{13} \mathrm{C} \mathrm{NMR}$ $\left(\mathrm{CD}_{3} \mathrm{OD}, 100 \mathrm{MHz}\right): \delta$ ppm 28.9, 44.8, 80.3, 105.2 (d, J = 24.2 Hz), 107.6 (d, $J=24.2 \mathrm{~Hz}$ ), 114.8, 122.7, $128.8,132.1(\mathrm{~d}, J=11.1 \mathrm{~Hz}), 132.5,137.5,138.0,163.3(\mathrm{~d}, J=13.3 \mathrm{~Hz}), 167.4(\mathrm{~d}, J=$ $251.3 \mathrm{~Hz}), 168.4 ; \mathrm{HPLC}, \mathrm{RT}=1.88 \mathrm{~min} ; \mathrm{MS}(\mathrm{ESI}+): \mathrm{m} / \mathrm{z} 383.1[\mathrm{M}+\mathrm{Na}]^{+}, 361.1[\mathrm{M}+\mathrm{H}]+, 305.1$ $[\mathrm{M}+\mathrm{H}-\mathrm{tBu}]^{+}$; HRMS calcd for $\mathrm{C}_{19} \mathrm{H}_{22} \mathrm{FN}_{2} \mathrm{O}_{4}$ 361.1558, found 361.1554.

Tert-butyl (4-(1-hydroxy-2-naphtoyl))aminobenzylcarbamate (14). Elution : $n$-Hex/AcOEt 3/1 v/v; White solid ( $m=40 \mathrm{mg}, 23 \%$ yield); $\mathrm{mp}: 145-146^{\circ} \mathrm{C} ;{ }^{1} \mathrm{H}$ NMR (DMSO $d_{6}, 300 \mathrm{MHz}$ ): $\delta \mathrm{ppm}$ $1.40(\mathrm{~s}, 9 \mathrm{H}), 4.13(\mathrm{~d}, 2 \mathrm{H}, J=5.9 \mathrm{~Hz}), 7.27(\mathrm{~d}, 2 \mathrm{H}, J=8.1 \mathrm{~Hz}), 7.40$ (bt, $1 \mathrm{H}, J=5.9 \mathrm{~Hz}), 7.46$ (d, $1 \mathrm{H}, J=8.9 \mathrm{~Hz}), 7.58(\mathrm{dd}, 1 \mathrm{H}, J=8.1 \mathrm{~Hz}, 7.1 \mathrm{~Hz}), 7.68(\mathrm{~m}, 3 \mathrm{H}), 7.92(\mathrm{~d}, 1 \mathrm{H}, J=8.1 \mathrm{~Hz}), 8.10(\mathrm{~d}$, $1 \mathrm{H}, J=9.0 \mathrm{~Hz}$ ), $8.31\left(\mathrm{~d}, 1 \mathrm{H}, J=8.1 \mathrm{~Hz}\right.$ ), $10.92(\mathrm{bs}, 1 \mathrm{H}) ;{ }^{13} \mathrm{C}$ NMR (DMSO $\left.d_{6}, 75 \mathrm{MHz}\right): \delta \mathrm{ppm}$ 28.2 , 43.0, $77.8,107.5,117.7,121.1,123.0,124.7,125.9,127.2,127.5,129.1,136.0,136.1$, 136.7, 155.8, 160.0, 169.4; HPLC, RT= $2.13 \mathrm{~min}$; MS (ESI+): m/z $415.1[\mathrm{M}+\mathrm{Na}]^{+}, 337.0[\mathrm{M}+\mathrm{H}-$ tBu] $]^{+}$; HRMS calcd for $\mathrm{C}_{23} \mathrm{H}_{25} \mathrm{~N}_{2} \mathrm{O}_{4}$ 393.1809, found 393.1807. 
Tert-butyl (4-(2-hydroxy-1-naphtoyl))aminobenzylcarbamate (15). Elution: DCM/EtOH 98.5/1.5 v/v; White solid ( $\mathrm{m}=90 \mathrm{mg}, 51 \%$ yield); $\mathrm{mp}: 188.5-189.5^{\circ} \mathrm{C} ;{ }^{1} \mathrm{H} \mathrm{NMR}\left(\mathrm{CDCl}_{3}, 300 \mathrm{MHz}\right)$ : $\delta$ ppm $1.45(\mathrm{~s}, 9 \mathrm{H}), 4.28(\mathrm{~d}, 2 \mathrm{H}, J=5.6 \mathrm{~Hz}), 4.88(\mathrm{bs}, 1 \mathrm{H}), 7.16(\mathrm{~d}, 1 \mathrm{H}, J=9.0 \mathrm{~Hz}), 7.29(\mathrm{~d}, 2 \mathrm{H}, J$ $=8.8 \mathrm{~Hz}), 7.36(\mathrm{dd}, 1 \mathrm{H}, J=7.4 \mathrm{~Hz}, 6.8 \mathrm{~Hz}), 7.54(\mathrm{~m}, 3 \mathrm{H}), 7.81(\mathrm{~m}, 2 \mathrm{H}), 8.01(\mathrm{bs}, 1 \mathrm{H}), 8.14(\mathrm{~d}, 1 \mathrm{H}$, $J=8.6 \mathrm{~Hz}), 10.92(\mathrm{bs}, 1 \mathrm{H}) ;{ }^{13} \mathrm{C} \mathrm{NMR}\left(\mathrm{CDCl}_{3}, 75 \mathrm{MHz}\right): \delta \mathrm{ppm} \mathrm{28.6,} \mathrm{44.4,} \mathrm{79.9,} \mathrm{110.3,} \mathrm{119.5,}$ 121.0, 122.6, 123.8, 128.4, 128.6, 129.0, 129.7, 130.7, 134.4, 136.2, 136.3, 156.0, 159.7, 168.5; HPLC, RT= $1.74 \mathrm{~min} ; \mathrm{MS}(\mathrm{ESI}+): \mathrm{m} / \mathrm{z} 415.1[\mathrm{M}+\mathrm{Na}]^{+}, 337.0[\mathrm{M}+\mathrm{H}-\mathrm{tBu}]^{+}$; HRMS calcd for $\mathrm{C}_{23} \mathrm{H}_{25} \mathrm{~N}_{2} \mathrm{O}_{4}$ 393.1809, found 393.1801.

Tert-butyl (4-(3-hydroxy-2-naphtoyl))aminobenzylcarbamate (16). White solid ( $\mathrm{m}=56 \mathrm{mg}$, 32\% yield); mp: $199-200^{\circ} \mathrm{C} ;{ }^{1} \mathrm{H}$ NMR (DMSO d $6,400 \mathrm{MHz}$ ): $\delta$ ppm 1.40 (s, 9H), 4.11 (d, $2 \mathrm{H}, J=$ $6.1 \mathrm{~Hz}), 7.25(\mathrm{~d}, 2 \mathrm{H}, J=8.4 \mathrm{~Hz}), 7.32(\mathrm{~s}, 1 \mathrm{H}), 7.35(\mathrm{~m}, 2 \mathrm{H}), 7.50(\mathrm{ddd}, 1 \mathrm{H}, J=8.4 \mathrm{~Hz}, J=6.8 \mathrm{~Hz}$, $J=1.0 \mathrm{~Hz}), 7.69(\mathrm{~d}, 2 \mathrm{H}, J=8.4 \mathrm{~Hz}), 7.75(\mathrm{~d}, 1 \mathrm{H}, J=8.2 \mathrm{~Hz}), 7.92(\mathrm{~d}, 1 \mathrm{H}, J=8.2 \mathrm{~Hz}), 8.51(\mathrm{~s}, 1 \mathrm{H})$, 10.65 (bs, $1 \mathrm{H}$ ); ${ }^{13} \mathrm{C}$ NMR (DMSO $d_{6}, 100 \mathrm{MHz}$ ): $\delta$ ppm 28.2, 43.0, 77.7, 110.6, 120.5, 121.6, 123.7, 125.7, 126.8, 127.4, 128.1, 128.7 130.4, 135.8, 135.9, 137.0, 154.0, 155.8, 165.6; HPLC, $\mathrm{RT}=1.99 \mathrm{~min} ; \mathrm{MS}(\mathrm{ESI}+): \mathrm{m} / \mathrm{z} 415.2[\mathrm{M}+\mathrm{Na}]^{+}, 337.1[\mathrm{M}+\mathrm{H}-\mathrm{tBu}]^{+} ; \mathrm{HRMS}$ calcd for $\mathrm{C}_{23} \mathrm{H}_{25} \mathrm{~N}_{2} \mathrm{O}_{4}$ 393.1809, found 393.1810.

Tert-butyl (4-(2-naphtoyl))aminobenzylcarbamate (17). White solid ( $\mathrm{m}=61 \mathrm{mg}, 36 \%$ yield); mp: $182.5-183.5^{\circ} \mathrm{C} ;{ }^{1} \mathrm{H} \mathrm{NMR}\left(\mathrm{CDCl}_{3}, 400 \mathrm{MHz}\right): \delta \mathrm{ppm} 1.45(\mathrm{~s}, 9 \mathrm{H}), 4.28(\mathrm{~d}, 2 \mathrm{H}, J=5.3 \mathrm{~Hz}), 4.86$ (bs, $1 \mathrm{H}), 7.28(\mathrm{~d}, 2 \mathrm{H}, J=8.4 \mathrm{~Hz}), 7.56(\mathrm{~m}, 2 \mathrm{H}), 7.63(\mathrm{~d}, 2 \mathrm{H}, J=8.4 \mathrm{~Hz}), 7.91(\mathrm{~m}, 4 \mathrm{H}), 8.03$ (bs, 1H), $8.36(\mathrm{~s}, 1 \mathrm{H}) ;{ }^{13} \mathrm{C} \mathrm{NMR}\left(\mathrm{CDCl}_{3}, 100 \mathrm{MHz}\right): \delta \mathrm{ppm} 28.6,44.5,79.8,120.7,123.8,127.2,127.8$, $128.0,128.1,128.5,129.0,129.2,132.3,132.8,135.1,135.4,137.4,156.1,166.0 ;$ HPLC, RT= $1.91 \mathrm{~min} ; \mathrm{MS}(\mathrm{ESI}+): \mathrm{m} / \mathrm{z} 377.1[\mathrm{M}+\mathrm{H}]^{+}, 399.1[\mathrm{M}+\mathrm{Na}]^{+}, 321.3[\mathrm{M}+\mathrm{H}-\mathrm{tBu}]^{+} ; \mathrm{HRMS}$ calcd for $\mathrm{C}_{23} \mathrm{H}_{25} \mathrm{~N}_{2} \mathrm{O}_{3} 377.1860$, found 377.1855. 
Tert-butyl (1H-2-indolylcarbonyl)aminobenzylcarbamate (18). White solid ( $\mathrm{m}=67 \mathrm{mg}, 41 \%$ yield); mp: 207-208 ${ }^{\circ} \mathrm{C} ; 1 \mathrm{H}$ NMR (DMSO $d_{6}, 400 \mathrm{MHz}$ ): $\delta$ ppm $1.40(\mathrm{~s}, 9 \mathrm{H}), 4.10(\mathrm{~s}, 2 \mathrm{H}), 7.06$ (t, $1 \mathrm{H}, J=7.5 \mathrm{~Hz}), 7.22(\mathrm{~m}, 3 \mathrm{H}), 7.36(\mathrm{bs}, 1 \mathrm{H}), 7.40(\mathrm{~s}, 1 \mathrm{H}), 7.46(\mathrm{~d}, 1 \mathrm{H}, J=8.3 \mathrm{~Hz}), 7.66(\mathrm{~d}, 1 \mathrm{H}, J=$ $7.5 \mathrm{~Hz}$ ), 7.72 (d, 2H, J = 8.3 Hz), 10.2 (bs, $1 \mathrm{H}), 11.76$ (bs, $1 \mathrm{H}) ;{ }^{13} \mathrm{C}$ NMR (DMSO $d_{6}, 100 \mathrm{MHz}$ ): $\delta$ ppm 28.3, 40.0, 77.7, 103.8, 112.4, 119.8, 120.1, 121.7, 123.7, 127.0, 127.3, 131.6, 135.3, 136.9, 137.5, 155.7, 159.7; HPLC, RT= $1.82 \mathrm{~min} ; \mathrm{MS}(\mathrm{ESI}+): \mathrm{m} / \mathrm{z} 388.2[\mathrm{M}+\mathrm{Na}]^{+}, 310.2[\mathrm{M}+\mathrm{H}-$ tBu] $]^{+}$; HRMS calcd for $\mathrm{C}_{21} \mathrm{H}_{24} \mathrm{~N}_{3} \mathrm{O}_{3} 366.1812$, found 366.1812 .

Tert-butyl (4-[(4-oxo-1,4-dihydroquinolin-3-yl)carbonyl]aminobenzylcarbamate (19). White solid ( $m=48 \mathrm{mg}, 27 \%$ yield); mp: $238-239^{\circ} \mathrm{C} ;{ }^{1} \mathrm{H}$ NMR (DMSO $d_{6}, 400 \mathrm{MHz}$ ): $\delta$ ppm $1.40(\mathrm{~s}, 9 \mathrm{H}$ ), $4.08(\mathrm{~d}, 2 \mathrm{H}, J=6.0 \mathrm{~Hz}), 7.17(\mathrm{~d}, 2 \mathrm{H}, J=8.3 \mathrm{~Hz}), 7.24(\mathrm{td}, 1 \mathrm{H}, J=8.1 \mathrm{~Hz}, 1.1 \mathrm{~Hz}), 7.33(\mathrm{t}, 1 \mathrm{H}, J=$ $6.1 \mathrm{~Hz}$ ), $7.50(\mathrm{td}, 1 \mathrm{H}, J=8.1 \mathrm{~Hz}, 1.5 \mathrm{~Hz}), 7.59(\mathrm{~d}, 1 \mathrm{H}, J=8.1 \mathrm{~Hz}), 7.66(\mathrm{~d}, 2 \mathrm{H}, J=8.3 \mathrm{~Hz}), 8.24$ (dd, $1 \mathrm{H}, J=8.1 \mathrm{~Hz}, 1.1 \mathrm{~Hz}$ ), $8.87(\mathrm{~s}, 1 \mathrm{H}), 13.64(\mathrm{~s}, 1 \mathrm{H}) ;{ }^{13} \mathrm{C}$ NMR (DMSO $d_{6}, 100 \mathrm{MHz}$ ): $\delta \mathrm{ppm}$ $28.3,43.1,77.7,108.6,118.9,122.2,124.7,126.7,127.5,127.6,129.3,133.5,139.0,149.3$ 151.6, 155.8, 166.1, 174.0; HPLC, RT= $1.67 \mathrm{~min} ; \mathrm{MS}(\mathrm{ESI}+): \mathrm{m} / \mathrm{z} 394.2[\mathrm{M}+\mathrm{H}]^{+}, 338.2[\mathrm{M}+\mathrm{H}-$ tBu] ${ }^{+}$; HRMS calcd for $\mathrm{C}_{22} \mathrm{H}_{24} \mathrm{~N}_{3} \mathrm{O}_{4} 394.1761$, found 394.1756.

Tert-butyl (4-(3-hydroxypyridin-2-yl))aminobenzylcarbamate (20). Light yellow solid ( $m=30$ mg, 19\% yield); mp: $\left.90-92^{\circ} \mathrm{C} ;{ }^{1} \mathrm{H} \mathrm{NMR} \mathrm{(CDCl} 3,400 \mathrm{MHz}\right): \delta$ ppm 1.45 (s, 9H), 4.29 (d, $2 \mathrm{H}, \mathrm{J}=5.7$ $\mathrm{Hz}), 7.30(\mathrm{~d}, 2 \mathrm{H}, J=8.4 \mathrm{~Hz}), 7.31-7.37(\mathrm{~m}, 2 \mathrm{H}), 7.65(\mathrm{~d}, 2 \mathrm{H}, J=8.4 \mathrm{~Hz}), 8.06(\mathrm{bs}, 1 \mathrm{H}), 8.10$ (dd, $1 \mathrm{H}, J=4.1 \mathrm{~Hz}, 1.6 \mathrm{~Hz}$ ), 9.90 (bs, 1H), 11.89 (s, 1H); HPLC, RT= $1.85 \mathrm{~min} ; \mathrm{MS}$ (ESI+): m/z 366.1 $[\mathrm{M}+\mathrm{Na}]^{+}$.

Tert-butyl (4-(6-methoxy-1-hydroxy-2-naphtoyl))aminobenzylcarbamate (21). White solid ( $m=34 \mathrm{mg}, 18 \%$ yield); mp: $205.8-206.3^{\circ} \mathrm{C} ;{ }^{1} \mathrm{H}$ NMR (CDCl $3,300 \mathrm{MHz}$ ): $\delta$ ppm 1.48 (s, 9H), 3.94 
$(\mathrm{s}, 3 \mathrm{H}), 4.30(\mathrm{~d}, 2 \mathrm{H}, J=5.4 \mathrm{~Hz}), 4.87(\mathrm{bs}, 1 \mathrm{H}), 7.07(\mathrm{~d}, 1 \mathrm{H}, J=2.3 \mathrm{~Hz}), 7.16(\mathrm{dd}, 1 \mathrm{H}, J=9.1 \mathrm{~Hz}$, $2.4 \mathrm{~Hz}), 7.20(\mathrm{~d}, 1 \mathrm{H}, J=8.1 \mathrm{~Hz}), 7.30(\mathrm{~d}, 2 \mathrm{H}, J=8.3 \mathrm{~Hz}), 7.44(\mathrm{~d}, 1 \mathrm{H}, J=9.1 \mathrm{~Hz}), 7.55(\mathrm{~d}, 2 \mathrm{H}, J=$ $8.3 \mathrm{~Hz}), 7.98(\mathrm{bs}, 1 \mathrm{H}), 8.35(\mathrm{~d}, 1 \mathrm{H}, J=9.1 \mathrm{~Hz}) ;{ }^{13} \mathrm{C} \mathrm{NMR}\left(\mathrm{CDCl}_{3}, 75 \mathrm{MHz}\right): \delta \mathrm{ppm} 28.6,44.4,55.5$, $79.3,105.4,106.2,117.6,118.2,121.0,121.6,121.7,125.9,128.4,136.0,136.2,138.6,142.7$, 143.1, 160.6, 161.6; HPLC, RT= $2.14 \mathrm{~min} ; \mathrm{MS}(\mathrm{ESI}+): \mathrm{m} / \mathrm{z} 445.2[\mathrm{M}+\mathrm{Na}]^{+}, 367.1[\mathrm{M}+\mathrm{H}-\mathrm{tBu}]^{+}$; HRMS calcd for $\mathrm{C}_{24} \mathrm{H}_{27} \mathrm{~N}_{2} \mathrm{O}_{5} 423.1914$, found 423.1911 .

Tert-butyl (4-(7-methoxy-1-hydroxy-2-naphtoyl))aminobenzylcarbamate (22). White solid (m= $30 \mathrm{mg}, 16 \%$ yield); ${ }^{1} \mathrm{H}$ NMR $\left(\mathrm{CDCl}_{3}, 400 \mathrm{MHz}\right): \delta \mathrm{ppm} 1.40(\mathrm{~s}, 9 \mathrm{H}), 3.89(\mathrm{~s}, 3 \mathrm{H}), 4,24(\mathrm{~d}, 2 \mathrm{H}$, $J=5.4 \mathrm{~Hz}), 4.81(\mathrm{bs}, 1 \mathrm{H}), 7.17-7.29(\mathrm{~m}, 6 \mathrm{H}), 7.49(\mathrm{~d}, 1 \mathrm{H}, J=8.3 \mathrm{~Hz}), 7.60(\mathrm{~d}, 1 \mathrm{H}, J=8.9 \mathrm{~Hz}), 7.65$ (d, $1 \mathrm{H}, J=2.4 \mathrm{~Hz}), 7.98(\mathrm{bs}, 1 \mathrm{H}), 13.38(\mathrm{~s}, 1 \mathrm{H}) ;{ }^{13} \mathrm{C} \mathrm{NMR}\left(\mathrm{CDCl}_{3}, 400 \mathrm{MHz}\right): \delta \mathrm{ppm} \mathrm{28.6,29.9}$, $44.4,55.7,79.9,102.2,107.4,118.5,118.6,121.7,122.0,126.9,128.5,129.1,131.9,136.2$ 156.1, 158.3, 160.3, 169.5; HPLC, RT= 2,12 min ; MS (ESI+) : m/z $423.1[M+H]^{+}, \mathrm{m} / \mathrm{z} 845.3$ $[2 \mathrm{M}+\mathrm{H}]^{+}, \mathrm{m} / \mathrm{z} 440.2\left[\mathrm{M}+\mathrm{NH}_{4}\right]^{+}$.

Tert-butyl (4-(7-methyl-1-hydroxy-2-naphtoyl))aminobenzylcarbamate (23). Elution: $n$ Hex/AcOEt 4/1 v/v. White solid ( $m=140 \mathrm{mg}, 77 \%$ yield); $\mathrm{mp}: 188.3-188.9^{\circ} \mathrm{C} ;{ }^{1} \mathrm{H} \mathrm{NMR}\left(\mathrm{CDCl}_{3}\right.$, $500 \mathrm{MHz}$ ): $\delta$ ppm $1.41(\mathrm{~s}, 9 \mathrm{H}), 2.47(\mathrm{~s}, 3 \mathrm{H}), 4.22(\mathrm{~d}, 2 \mathrm{H}, J=5.8 \mathrm{~Hz}), 4.84(\mathrm{bt}, 1 \mathrm{H}), 7.20(\mathrm{~m}, 3 \mathrm{H})$, $7.34(\mathrm{~d}, 1 \mathrm{H}, J=9.0 \mathrm{~Hz}), 7.36(\mathrm{dd}, 1 \mathrm{H}, J=8.4 \mathrm{~Hz}, 1.4 \mathrm{~Hz}), 7.46(\mathrm{~d}, 1 \mathrm{H}, J=8.1 \mathrm{~Hz}), 7.60(\mathrm{~d}, 1 \mathrm{H}, J=$ $8.4 \mathrm{~Hz}), 8.05$ (bs, $1 \mathrm{H}), 8.15(\mathrm{~s}, 1 \mathrm{H}), 13.45(\mathrm{~s}, 1 \mathrm{H}) ;{ }^{13} \mathrm{C} \mathrm{NMR}\left(\mathrm{CDCl}_{3}, 125 \mathrm{MHz}\right): \delta \mathrm{ppm}$ 22.0, 28.6, $44.3,79.9,107.0,118.5,120.0,121.8,123.0,125.9,127.4,128.4,131.6,134.8,136.0,136.1$ 136.2, 156.1, 161.0, 169.5; HPLC, RT= $2.23 \mathrm{~min} ; \mathrm{MS}(\mathrm{ESI}+): \mathrm{m} / \mathrm{z} 429.1[\mathrm{M}+\mathrm{Na}]^{+}, 407.2[\mathrm{M}+\mathrm{H}]^{+}$, $351.1[\mathrm{M}+\mathrm{H}-\mathrm{tBu}]^{+}$; HRMS calcd for $\mathrm{C}_{24} \mathrm{H}_{27} \mathrm{~N}_{2} \mathrm{O}_{4} 407.1965$, found 407.1962. 
Tert-butyl (4-(7-chloro-1-hydroxy-2-naphtoyl))aminobenzylcarbamate (24). White solid (m= $101 \mathrm{mg}, 53 \%$ yield); $\mathrm{RMN}^{1} \mathrm{H}\left(\mathrm{CDCl}_{3}, 400 \mathrm{MHz}\right): \delta \mathrm{ppm} 1.58(\mathrm{~s}, 9 \mathrm{H}), 4.32(\mathrm{~d}, 2 \mathrm{H}, J=5.7 \mathrm{~Hz}), 4.88$ (bs, 1H), $7.33(\mathrm{~m}, 3 \mathrm{H}), 7.48(\mathrm{~d}, 1 \mathrm{H}, J=8.8 \mathrm{~Hz}), 7.55(\mathrm{dd}, 1 \mathrm{H}, J=8.8 \mathrm{~Hz}, 2.2 \mathrm{~Hz}), 7.57(\mathrm{~d}, 2 \mathrm{H}, J=$ $8.3 \mathrm{~Hz}), 7.72(\mathrm{~d}, 1 \mathrm{H}, J=8.7 \mathrm{~Hz}), 8.00(\mathrm{~s}, 1 \mathrm{H}), 8.43(\mathrm{~d}, 1 \mathrm{H}, J=2.2 \mathrm{~Hz}), 13.51(\mathrm{~s}, 1 \mathrm{H}) ; \mathrm{RMN}^{13} \mathrm{C}$ $\left(\mathrm{CDCl}_{3}, 400 \mathrm{MHz}\right): \delta$ ppm 28.6, 44.4, 79.9, 107.7, 118.4, 121.1, 121.7, 123.4, 126.6, 128.5, 129.2, 130.2, 132.4, 134.7, 135.9, 136.4, 156.1, 160.6, 169.0; HPLC, RT= 2,12 min; MS (ESI+): $\mathrm{m} / \mathrm{z} 371.1[\mathrm{M}+\mathrm{H}-\mathrm{tBu}]^{+}, 373.1[\mathrm{M}+\mathrm{H}-\mathrm{tBu}+2]^{+}, 444.1\left[\mathrm{M}+\mathrm{NH}_{4}\right]^{+}, 446.1\left[\mathrm{M}+\mathrm{NH}_{4}+2\right]^{+}, 427.1[\mathrm{M}+\mathrm{H}]^{+}$, $429.1[\mathrm{M}+\mathrm{H}+2]^{+}$.

Tert-butyl (4-(6,7-dimethoxy-1-hydroxy-2-naphtoyl))aminobenzylcarbamate (25). ELution: nHex/AcOEt 2/1 v/v. White solid ( $m=140 \mathrm{mg}, 69 \%$ yield); ${ }^{1} \mathrm{H} \mathrm{NMR}\left(\mathrm{CDCl}_{3}, 400 \mathrm{MHz}\right): \delta \mathrm{ppm}$ $1.47(\mathrm{~s}, 9 \mathrm{H}), 4.02(\mathrm{~s}, 3 \mathrm{H}), 4.04(\mathrm{~s}, 3 \mathrm{H}), 4.31(\mathrm{~d}, 2 \mathrm{H}, \mathrm{J}=5.4 \mathrm{~Hz}), 4.87$ (bs, $1 \mathrm{H}), 7.07(\mathrm{~s}, 1 \mathrm{H}), 7.18$ $(\mathrm{d}, 1 \mathrm{H}, J=8.7 \mathrm{~Hz}), 7.30(\mathrm{~d}, 2 \mathrm{H}, J=8.3 \mathrm{~Hz}), 7.36(\mathrm{~d}, 1 \mathrm{H}, J=8.8 \mathrm{~Hz}), 7.56(\mathrm{~d}, 2 \mathrm{H}, J=8.3 \mathrm{~Hz}), 7.70$ (s, 1H), $8.01(\mathrm{~s}, 1 \mathrm{H}), 13.44(\mathrm{~s}, 1 \mathrm{H}) ;{ }^{13} \mathrm{C} \mathrm{NMR}\left(\mathrm{CDCl}_{3}, 100 \mathrm{MHz}\right): \delta \mathrm{ppm} 28.6,44.4,56.2,56.3$, $79.8,102.9,106.1,106.5,117.3,119.5,120.7,121.7,128.5,131.1,133.0,136.0,136.3,149.6$, 152.1, 160.2, 169.5; HPLC, RT= 3.81 min; MS (ESI+): $\mathrm{m} / \mathrm{z} 397.2[\mathrm{M}+\mathrm{H}-\mathrm{tBu}]^{+}, 453.3[\mathrm{M}+\mathrm{H}]^{+}, 475.3$ $[\mathrm{M}+\mathrm{Na}]^{+}$.

\section{Synthesis of tert-butyl (4-(5-tert-butyl-2-hydroxybenzyl)amino)benzyl)carbamate (29).}

To a solution of $100 \mathrm{mg}$ of compound $2(0.45 \mathrm{mmol})$ in $2.5 \mathrm{~mL}$ of ethanol were added $80 \mathrm{mg}$ of aldehyde 26 ( $0.45 \mathrm{mmol}, 1$ equiv.). The solution was stirred at reflux for 6 hours. After cooling to room temperature, were added $9 \mathrm{mg}$ of sodium borohydride $(0.235 \mathrm{mmol}, 0.5$ equiv.) and the solution was stirred at room temperature for $1 \mathrm{~h} 30$. Then, $20 \mathrm{~mL}$ of water were added and the solution was extracted with ethyl acetate $(3 \times 20 \mathrm{~mL})$. The organic layer was 
dried over $\mathrm{Na}_{2} \mathrm{SO}_{4}$, filtered and the solvent is evaporated in vacuo to offer compound $\mathbf{3 0}$ as a white solid ( $\mathrm{m}=110 \mathrm{mg}, 64 \%$ yield); $\mathrm{mp} 102.0-103.0^{\circ} \mathrm{C} ;{ }^{1} \mathrm{H} \mathrm{NMR}\left(\mathrm{CDCl}_{3}, 300 \mathrm{MHz}\right): \delta \mathrm{ppm} 1.29$ (s, 9H), $1.44(\mathrm{~s}, 9 \mathrm{H}), 4.19(\mathrm{~d}, 2 \mathrm{H}, J=5.6 \mathrm{~Hz}), 4.35(\mathrm{~s}, 2 \mathrm{H}), 4.81(\mathrm{bs}, 2 \mathrm{H}), 6.76(\mathrm{~d}, 2 \mathrm{H}, J=8.4 \mathrm{~Hz})$, $6.81(\mathrm{~d}, 1 \mathrm{H}), 7.12(\mathrm{~m}, 3 \mathrm{H}), 7.21(\mathrm{dd}, 1 \mathrm{H}, J=8.4 \mathrm{~Hz}, 2.4 \mathrm{~Hz}), 11.2(\mathrm{~s}, 1 \mathrm{H}) ;{ }^{13} \mathrm{C} \mathrm{NMR}\left(\mathrm{CDCl}_{3}, 75\right.$ MHz): $\delta$ ppm 28.6, 31.7, 44.4, 48.8, 64.9, 79.6, 115.8, 116.1, 122.4, 124.9, 125.8, 126.1, 128.8, 130.9, 143.0, 146.9, 154.2; HPLC, RT= $3.57 \mathrm{~min} ; \mathrm{MS}(\mathrm{ESI}+): \mathrm{m} / \mathrm{z} 329.1[\mathrm{M}+\mathrm{H}-\mathrm{tBu}]^{+}, 385.1$ $[\mathrm{M}+\mathrm{H}]^{+}, 407.1[\mathrm{M}+\mathrm{Na}]^{+} ; \mathrm{HRMS}$ calcd for $\mathrm{C}_{23} \mathrm{H}_{33} \mathrm{~N}_{2} \mathrm{O}_{3} 385.2486$, found 385.2499.

\section{Synthesis of tert-butyl 4-[(1-hydroxy-2-naphthoyl)amino]piperidine-1-carboxylate (52):}

To a solution of $91 \mathrm{mg}$ of compound 1-Boc-4-aminopiperidine $(0.45 \mathrm{mmol})$ in $2.5 \mathrm{~mL}$ of THF was added $86 \mathrm{mg}$ of 1-hydroxy-2-naphtoic acid (1 equiv., $0.45 \mathrm{mmol}$ ) and $103 \mathrm{mg}$ of EDCl (1 equiv., $0.45 \mathrm{mmol}$ ). The solution was stirred at reflux for 12 hours. After cooling to room temperature, the solution was evaporated to dryness. The crude product was dissolved in 20 $\mathrm{mL}$ of ethyl acetate and the solution was washed with $1 \mathrm{~N}$ hydrochloric acid solution $(3 \times 20 \mathrm{~mL})$ and then by $10 \%$ aqueous sodium carbonate solution. The organic layer was dried over $\mathrm{Na}_{2} \mathrm{SO}_{4}$, filtered and the solvent is evaporated in vacuo. The resulting crude mixture was purified by chromatography on silica gel, eluted by $n$ Hex/AcOEt $3 / 1 \mathrm{v} / \mathrm{v}$, to offer compound 52 as a white solid ( $\mathrm{m}=38 \mathrm{mg}, 23 \%$ yield); ${ }^{1} \mathrm{H} \mathrm{NMR}\left(\mathrm{CDCl}_{3}, 400 \mathrm{MHz}\right): \delta \mathrm{ppm} 1.23(\mathrm{~m}, 1 \mathrm{H}), 1.42$ $(\mathrm{m}, 1 \mathrm{H}), 1.46(\mathrm{~s}, 9 \mathrm{H}), 2.04(\mathrm{~m}, 2 \mathrm{H}), 2.90(\mathrm{t}, 2 \mathrm{H}, J=12.1 \mathrm{~Hz}), 4.07-4.19(\mathrm{~m}, 3 \mathrm{H}), 6.25(\mathrm{~d}, 1 \mathrm{H}, J=$ $7.7 \mathrm{~Hz}$ ), $7.23(\mathrm{~d}, 1 \mathrm{H}, J=8.8 \mathrm{~Hz}), 7.28(\mathrm{~d}, 1 \mathrm{H}, J=8.9 \mathrm{~Hz}), 7.50(\mathrm{td}, 1 \mathrm{H}, J=8.2 \mathrm{~Hz}, 1.3 \mathrm{~Hz}), 7.56$ (td, $1 \mathrm{H}, J=8.2 \mathrm{~Hz}, 1.3 \mathrm{~Hz}), 7.74(\mathrm{~d}, 1 \mathrm{H}, J=7.8 \mathrm{~Hz}), 8.40(\mathrm{~d}, 1 \mathrm{H}, J=8.2 \mathrm{~Hz}), 13.75(\mathrm{~s}, 1 \mathrm{H}) ;{ }^{13} \mathrm{C}$ NMR (CDCl $3,100 \mathrm{MHz}): \delta$ ppm 28.6, 29.8, 32.2, 47.3, 80.0, 106.6, 118.3, 120.9, 124.0, 125.8, 126.0, 127.4, 129.1, 136.4, 154.8, 160.9, 170.2; HPLC, RT= $2.16 \mathrm{~min}$; MS (ESI+): m/z 371.2 $[\mathrm{M}+\mathrm{H}]^{+}, 315.2[\mathrm{M}+\mathrm{H}-\mathrm{tBu}]^{+}$. 


\section{General procedure for the synthesis of compounds 28-51 and 53.}

$0.2 \mathrm{mmol}$ of compound 3-25, 27 or $\mathbf{5 2}$ in $5 \mathrm{~mL}$ of $6 \mathrm{~N} \mathrm{HCl}$ in dioxane was stirred a room temperature for $1 \mathrm{~h} 30$. The dioxane was evaporated and the crude product was washed with diethyl ether to offer deprotected compound as a hydrochloride salt.

$N$-(4-(aminomethyl)phenyl)-5-tert-butyl-2-hydroxybenzamide hydrochloride (28). White solid (m= $54 \mathrm{mg}, 80 \%$ yield); mp: $268-269^{\circ} \mathrm{C} ;{ }^{1} \mathrm{H}$ NMR (DMSO $d_{6}, 300 \mathrm{MHz}$ ): $\delta \mathrm{ppm} 1.30(\mathrm{~s}, 9 \mathrm{H}), 3.56$ (s, 1H), $3.99(\mathrm{~s}, 2 \mathrm{H}), 6.97(\mathrm{~d}, 1 \mathrm{H}, J=8.2 \mathrm{~Hz}), 7.50(\mathrm{~m}, 3 \mathrm{H}), 7.72(\mathrm{~d}, 2 \mathrm{H}, J=7.0 \mathrm{~Hz}), 7.94(\mathrm{~s}, 1 \mathrm{H})$, 8.42 (bs, 3H), 10.52 (s, $1 \mathrm{H}$ ); ${ }^{13} \mathrm{C}$ NMR (DMSO $d_{6}, 75 \mathrm{MHz}$ ): $\delta$ ppm 31.2, 41.8, 66.3, 116.7, 116.9, $120.9,122.8,125.5,129.4,130.6,138.3,141.3,155.7,166.3 ; \mathrm{HPLC}, \mathrm{RT}=1.45 \mathrm{~min} ; \mathrm{HRMS}$ calcd for $\mathrm{C}_{18} \mathrm{H}_{23} \mathrm{~N}_{2} \mathrm{O}_{2} 299.1754$, found 299.1752 .

2-(4-aminomethylphenyl)aminomethyl)-4-tert-butylphenol hydrochloride (29). White solid (m= $52 \mathrm{mg}, 73 \%$ yield); mp: $258-260^{\circ} \mathrm{C}$ (dec.); ${ }^{1} \mathrm{H}$ NMR (DMSO $d_{6}, 300 \mathrm{MHz}$ ): $\delta$ ppm 1.20 (s, 9H), $3.93(\mathrm{~d}, 2 \mathrm{H}, J=5.2 \mathrm{~Hz}), 4.31(\mathrm{bs}, 2 \mathrm{H}), 6.81(\mathrm{~d}, 1 \mathrm{H}, J=8.4 \mathrm{~Hz}), 7.15(\mathrm{~m}, 3 \mathrm{H}), 7.42(\mathrm{~m}, 3 \mathrm{H})$, 8.45 (bs, 3H), 10.43 (s, 1H); ${ }^{13} \mathrm{C}$ NMR (DMSO $d_{6}, 75 \mathrm{MHz}$ ): $\delta$ ppm 31.4, 33.7, 41.7, 46.3, 114.7, 119.0, 120.0, 123.2, 125.8, 127.5, 130.0, 130.3, 140.9, 153.3; HPLC, RT= 1.39 min; HRMS calcd for $\mathrm{C}_{18} \mathrm{H}_{25} \mathrm{~N}_{2} \mathrm{O} 285.1961$, found 285.1954.

$\mathrm{N}$-(4-(aminomethyl)phenyl)-2-hydroxybenzamide hydrochloride (30). White solid ( $\mathrm{m}=45 \mathrm{mg}$, 81\% yield); mp: $275-276^{\circ} \mathrm{C}$ (dec.); ${ }^{1} \mathrm{H}$ NMR (DMSO d $d_{6}, 300 \mathrm{MHz}$ ): $\delta$ ppm 3.99 (d, $2 \mathrm{H}, J=4.9 \mathrm{~Hz}$ ), $6.96(t, 1 \mathrm{H}, J=7.5 \mathrm{~Hz}), 7.04(\mathrm{~d}, 1 \mathrm{H}, J=8.4 \mathrm{~Hz}), 7.43(\mathrm{dd}, 1 \mathrm{H}, J=8.4 \mathrm{~Hz}, 7.2 \mathrm{~Hz}), 7.49(\mathrm{~d}, 2 \mathrm{H}, J=$ $8.4 \mathrm{~Hz}), 7.75(\mathrm{~d}, 2 \mathrm{H}, J=8.4 \mathrm{~Hz}), 8.01(\mathrm{~d}, 1 \mathrm{H}, J=7.2 \mathrm{~Hz}), 8.45(\mathrm{bs}, 3 \mathrm{H}), 10.51(\mathrm{~s}, 1 \mathrm{H}) ;{ }^{13} \mathrm{C} \mathrm{NMR}$ (DMSO $d_{6}, 75 \mathrm{MHz}$ ): $\delta p p m$ 41.7, 117.2, 117.5, 119.0, 120.8, 129.2, 129.4, 129.5, 133.6, 138.3, 
158.2, 166.4; HPLC, RT= 1.05 min; MS (ESI+): m/z $244.1[\mathrm{M}+\mathrm{H}+1]^{+} ; \mathrm{HRMS}$ calcd for $\mathrm{C}_{14} \mathrm{H}_{15} \mathrm{~N}_{2} \mathrm{O}_{2}$ 243.1128, found 243.1129 .

$N$-(4-(aminomethyl)phenyl)-3-methyl-2-hydroxybenzamide hydrochloride (31). Beige solid ( $m=54 \mathrm{mg}, 92 \%$ yield); mp: $275-276^{\circ} \mathrm{C} ;{ }^{1} \mathrm{H}$ NMR (DMSO $d_{6}, 400 \mathrm{MHz}$ ): $\delta$ ppm $2.20(\mathrm{~s}, 3 \mathrm{H}$ ), 4.00 $(\mathrm{q}, 2 \mathrm{H}, J=5.6 \mathrm{~Hz}), 6.88(\mathrm{t}, 1 \mathrm{H}, J=7.7 \mathrm{~Hz}), 7.38(\mathrm{~d}, 1 \mathrm{H}, J=7.7 \mathrm{~Hz}), 7.51(\mathrm{~d}, 2 \mathrm{H}, J=8.4 \mathrm{~Hz}), 7.75$ $\left(\mathrm{d}, 2 \mathrm{H}, J=8.4 \mathrm{~Hz}\right.$ ), $8.00(\mathrm{~d}, 1 \mathrm{H}, J=7.7 \mathrm{~Hz}), 8.45(\mathrm{bs}, 3 \mathrm{H}), 10.59(\mathrm{~s}, 1 \mathrm{H}), 12.53(\mathrm{~s}, 1 \mathrm{H}) ;{ }^{13} \mathrm{C} N M R$ (DMSO $d_{6}, 100 \mathrm{MHz}$ ): $\delta$ ppm 15.5, 41.7, 114.1, 118.0, 121.9, 125.5, 126.1, 129.4, 130.1, 135.1, 137.8, 159.2, 169.2; HPLC, RT= $1.22 \mathrm{~min}$; HRMS calcd for $\mathrm{C}_{15} \mathrm{H}_{17} \mathrm{~N}_{2} \mathrm{O}_{2}$ 257.1285, found 257.1292.

$\mathrm{N}$-(4-(aminomethyl)phenyl)-4-methyl-2-hydroxybenzamide hydrochloride (32). Beige solid (m= $53 \mathrm{mg}, 90 \%$ yield); mp: $282-283^{\circ} \mathrm{C}$ (dec.); ${ }^{1} \mathrm{H}$ NMR (DMSO $d_{6}, 400 \mathrm{MHz}$ ): $\delta$ ppm 2.30 (s, $3 \mathrm{H}), 3.98(\mathrm{q}, 2 \mathrm{H}, J=5.6 \mathrm{~Hz}), 6.78(\mathrm{~d}, 1 \mathrm{H}, J=8.2 \mathrm{~Hz}), 6.84(\mathrm{~s}, 1 \mathrm{H}), 7.48(\mathrm{~d}, 2 \mathrm{H}, J=8.4 \mathrm{~Hz}), 7.74$ $(\mathrm{d}, 2 \mathrm{H}, J=8.4 \mathrm{~Hz}), 7.94(\mathrm{~d}, 1 \mathrm{H}, J=8.2 \mathrm{~Hz}), 8.43(\mathrm{bs}, 3 \mathrm{H}), 10.46(\mathrm{~s}, 1 \mathrm{H}) ;{ }^{13} \mathrm{C}$ NMR (DMSO $d_{6}, 100$ MHz): $\delta$ ppm 21.1, 41.8, 114.2, 117.5, 120.1, 120.9, 129.0, 129.5, 130.3, 138.3, 144.4, 158.8, 166.7; HPLC, RT= 1.11 min; HRMS calcd for $\mathrm{C}_{15} \mathrm{H}_{17} \mathrm{~N}_{2} \mathrm{O}_{2} 257.1285$, found 257.1293.

$2 \mathrm{~N}$-(4-(aminomethyl)phenyl)-5-methyl-2-hydroxybenzamide hydrochloride (33). White solid ( $m=58 \mathrm{mg}, 99 \%$ yield); mp: $292-293^{\circ} \mathrm{C}$ (dec.); ${ }^{1} \mathrm{H}$ NMR (DMSO $d_{6}, 400 \mathrm{MHz}$ ): $\delta p p m ~ 2.28(\mathrm{~s}, 3 \mathrm{H}$ ), $3.98(\mathrm{q}, 2 \mathrm{H}, J=5.4 \mathrm{~Hz}), 6.92(\mathrm{~d}, 1 \mathrm{H}, J=8.3 \mathrm{~Hz}), 7.24(\mathrm{~d}, 1 \mathrm{H}, J=8.3 \mathrm{~Hz}), 7.48(\mathrm{~d}, 2 \mathrm{H}, J=8.4 \mathrm{~Hz})$, $7.74\left(\mathrm{~d}, 2 \mathrm{H}, \mathrm{J}=8.4 \mathrm{~Hz}\right.$ ), $7.82(\mathrm{~s}, 1 \mathrm{H}), 8.42(\mathrm{bs}, 3 \mathrm{H}), 10.49(\mathrm{~s}, 1 \mathrm{H}), 11.61(\mathrm{~s}, 1 \mathrm{H}) ;{ }^{13} \mathrm{C}$ NMR (DMSO $\left.d_{6}, 100 \mathrm{MHz}\right): \delta$ ppm 20.0, 41.8, 117.1, 120.7, 127.7, 129.1, 129.5, 130.2, 134.3, 138.4, 156.1, 166.5; HPLC, RT= 1.13 min; $\mathrm{HRMS}$ calcd for $\mathrm{C}_{15} \mathrm{H}_{17} \mathrm{~N}_{2} \mathrm{O}_{2} 257.1285$, found 257.1289. 
$\mathrm{N}$-(4-(aminomethyl)phenyl)-6-methyl-2-hydroxybenzamide hydrochloride (34). White solid (m= $58 \mathrm{mg}, 99 \%$ yield); mp: $251-252^{\circ} \mathrm{C}$ (dec.); ${ }^{1} \mathrm{H}$ NMR (CD $\left.\mathrm{OD}, 300 \mathrm{MHz}\right): \delta$ ppm $2.32(\mathrm{~s}, 3 \mathrm{H})$, $4.10(\mathrm{~s}, 2 \mathrm{H}), 6.72(\mathrm{~d}, 1 \mathrm{H}, J=8.0 \mathrm{~Hz}), 6.74(\mathrm{~d}, 1 \mathrm{H}, J=8.0 \mathrm{~Hz}), 7.13(\mathrm{t}, 1 \mathrm{H}, J=8.0 \mathrm{~Hz}), 7.44(\mathrm{~d}, 2 \mathrm{H}$, $J=8.5 \mathrm{~Hz}$ ), $7.78(\mathrm{~d}, 2 \mathrm{H}, J=8.5 \mathrm{~Hz}) ;{ }^{13} \mathrm{C}$ NMR (DMSO $d_{6}, 100 \mathrm{MHz}$ ): $\delta$ ppm 19.2, 44.0, 114.0, 121.7, 122.1, 126.6, 129,9, 130.6, 131.1, 137.5, 141.0, 155.5, 170.1; HPLC, RT=0.88 min; HRMS calcd for $\mathrm{C}_{15} \mathrm{H}_{17} \mathrm{~N}_{2} \mathrm{O}_{2} 257.1285$, found 257.1287.

$\mathrm{N}$-(4-(aminomethyl)phenyl)-5-bromo-2-hydroxybenzamide hydrochloride (35). Yellow solid (m= $71 \mathrm{mg}, 99 \%$ yield); mp: $309-310^{\circ} \mathrm{C} ;{ }^{1} \mathrm{H}$ NMR (DMSO $d_{6}, 400 \mathrm{MHz}$ ): $\delta \mathrm{ppm} 4.00$ (s, 2H), 7.01 (d, $1 \mathrm{H}, J=8.8 \mathrm{~Hz}), 7.47(\mathrm{~d}, 2 \mathrm{H}, J=8.6 \mathrm{~Hz}), 7.58(\mathrm{dd}, 1 \mathrm{H}, J=8.8 \mathrm{~Hz}, 2.4 \mathrm{~Hz}), 7.73(\mathrm{~d}, 2 \mathrm{H}, J=8.6$ $\mathrm{Hz}), 8.07(\mathrm{~d}, 1 \mathrm{H}, J=2.4 \mathrm{~Hz}), 8.32(\mathrm{bs}, 3 \mathrm{H}), 10.50(\mathrm{~s}, 1 \mathrm{H}), 11.90(\mathrm{bs}, 1 \mathrm{H}) ;{ }^{13} \mathrm{C} \mathrm{NMR}\left(\mathrm{CDCl}_{3}, 100\right.$ MHz): $\delta$ ppm 41.8, 110.2, 119.5, 120.7, 129.5, 129.7, 131.4, 135.9, 138.2, 157.1, 164.8; HPLC, $R T=1.21$ min; HRMS calcd for $\mathrm{C}_{14} \mathrm{H}_{14} \mathrm{~N}_{2} \mathrm{O}_{2} \mathrm{Br}$ 321.0233, found 321.0236.

$\mathrm{N}$-(4-(aminomethyl)phenyl)-5-methoxy-2-hydroxybenzamide hydrochloride (36). White solid (m= $55 \mathrm{mg}, 90 \%$ yield); mp: $277.5-278.5^{\circ} \mathrm{C} ;{ }^{1} \mathrm{H}$ NMR (DMSO $d_{6}, 300 \mathrm{MHz}$ ): $\delta \mathrm{ppm} 3.76(\mathrm{~s}, 3 \mathrm{H}$ ), $4.00(\mathrm{~s}, 2 \mathrm{H}), 6.95(\mathrm{~d}, 1 \mathrm{H}, J=8.8 \mathrm{~Hz}), 7.06(\mathrm{dd}, 1 \mathrm{H}, J=8.8 \mathrm{~Hz}, 2.2 \mathrm{~Hz}), 7.47(\mathrm{~d}, 2 \mathrm{H}, J=8.1 \mathrm{~Hz})$, $7.50(\mathrm{~d}, 1 \mathrm{H}, J=2.2 \mathrm{~Hz}), 7.74(\mathrm{~d}, 2 \mathrm{H}, J=8.1 \mathrm{~Hz}), 8.22(\mathrm{bs}, 3 \mathrm{H}), 10.54(\mathrm{~s}, 1 \mathrm{H}) ;{ }^{13} \mathrm{C}$ NMR (DMSO $d_{6}$, $75 \mathrm{MHz}): \delta$ ppm 41.8, 55.7, 112.7, 117.5, 118.2, 120.6, 120.8, 129.5, 129.6, 138.3, 151.8, 152.0, 165.9; $\mathrm{HPLC}, \mathrm{RT}=1.10 \mathrm{~min}$; $\mathrm{HRMS}$ calcd for $\mathrm{C}_{15} \mathrm{H}_{17} \mathrm{~N}_{2} \mathrm{O}_{3}$ 273.1234, found 273.1240.

N-(4-(aminomethyl)phenyl)-4-isopropyl-2-hydroxybenzamide hydrochloride (37). White solid (m = $63 \mathrm{mg}, 56 \%$ yield); mp: $282-283^{\circ} \mathrm{C} ;{ }^{1} \mathrm{H}$ NMR (DMSO $\left.d_{6}, 400 \mathrm{MHz}\right): \delta \mathrm{ppm} 1.20(\mathrm{~d}, 6 \mathrm{H}, J=$ $6.8 \mathrm{~Hz}$ ), 2.87 (hept, $1 \mathrm{H}, J=6.8 \mathrm{~Hz}), 3.99(\mathrm{~d}, 2 \mathrm{H}, J=3.9 \mathrm{~Hz}), 6.87(\mathrm{~m}, 2 \mathrm{H}), 7.48(\mathrm{~d}, 2 \mathrm{H}, J=8.3 \mathrm{~Hz})$, $7.74(\mathrm{~d}, 2 \mathrm{H}, J=8.3 \mathrm{~Hz}), 7.95(\mathrm{~d}, 1 \mathrm{H}, J=7.9 \mathrm{~Hz}), 8.39$ (bs, 3H), $10.5(\mathrm{~s}, 1 \mathrm{H}), 11.97(\mathrm{bs}, 1 \mathrm{H}) ;{ }^{13} \mathrm{C}$ 
NMR (DMSO $d_{6}, 100$ MHz): $\delta$ ppm 23.3, 33.3, 41.8, 114.6, 114.7, 117.4, 120.8, 129.0, 129.4, 138.3, 155.0, 158.8, 166.7; HPLC, RT= 1.33 min; HRMS calcd for $\mathrm{C}_{17} \mathrm{H}_{21} \mathrm{~N}_{2} \mathrm{O}_{2} 285.1598$, found 285.1603.

$\mathrm{N}$-(4-(aminomethyl)phenyl)-4-trifluoromethyl-2-hydroxybenzamide hydrochloride (38). White solid ( $m=67 \mathrm{mg}, 96 \%$ yield); $\mathrm{mp}: 270-272^{\circ} \mathrm{C}$ (dec.); ${ }^{1} \mathrm{H}$ NMR (DMSO $d_{6}, 400 \mathrm{MHz}$ ): $\delta$ ppm 3.99 (bs, 2H), $7.28(\mathrm{~d}, 1 \mathrm{H}, J=7.9 \mathrm{~Hz}), 7.39(\mathrm{~s}, 1 \mathrm{H}), 7.48(\mathrm{~d}, 2 \mathrm{H}, J=8.1 \mathrm{~Hz}), 7.76(\mathrm{~d}, 2 \mathrm{H}, J=$ $8.1 \mathrm{~Hz}), 8.03(\mathrm{~d}, 1 \mathrm{H}, J=7.9 \mathrm{~Hz}), 8.38$ (bs, 3H), $10.54(\mathrm{~s}, 1 \mathrm{H}), 11.97$ (bs, $1 \mathrm{H}) ;{ }^{19} \mathrm{~F}\left(\mathrm{DMSO} d_{6}, 400\right.$ MHz): $-61.77 ;{ }^{13} \mathrm{C}$ NMR (DMSO $d_{6}, 100 \mathrm{MHz}$ ): $\delta$ ppm 41.8, 113.4, 115.3, 120.3, 122.1, 123.5, 129.5, 130.7, 132.3, 132.6, 138.4, 157.1, 164.5; HPLC, RT= $1.29 \mathrm{~min} ; \mathrm{MS}(\mathrm{ESI}+): \mathrm{m} / \mathrm{z} 312.1$ $[\mathrm{M}+\mathrm{H}]^{+}, 294.1\left[\mathrm{M}+\mathrm{H}-\mathrm{NH}_{3}\right]^{+} ; \mathrm{HRMS}$ calcd for $\mathrm{C}_{15} \mathrm{H}_{14} \mathrm{~F}_{3} \mathrm{~N}_{2} \mathrm{O}_{2}$ 311.1002, found 311.1005.

N-(4-(aminomethyl)phenyl)-4-fluoro-2-hydroxybenzamide hydrochloride (39). White solid (m= $45 \mathrm{mg}, 76 \%$ yield); mp: $280-281^{\circ} \mathrm{C} ;{ }^{1} \mathrm{H}$ NMR (DMSO d $\left.6,400 \mathrm{MHz}\right): \delta \mathrm{ppm} 3.99(\mathrm{~s}, 2 \mathrm{H}$ ), $6.88-$ $6.80(\mathrm{~m}, 2 \mathrm{H}), 7.48(\mathrm{~d}, 2 \mathrm{H}, J=8.4 \mathrm{~Hz}), 7.74(\mathrm{~d}, 2 \mathrm{H}, J=8.4 \mathrm{~Hz}), 8.08(\mathrm{dd}, 1 \mathrm{H}, J=8.7 \mathrm{~Hz}, J=8.7$ $\mathrm{Hz}$ ), 8.36 (bs, 3H), 10.47 (s, 1H), 12.36 (bs, 1H); ${ }^{19} \mathrm{~F}$ (DMSO $d_{6}, 400 \mathrm{MHz}$ ): $-105.70 ;{ }^{13} \mathrm{C}$ NMR (DMSO $d_{6}, 100 \mathrm{MHz}$ ): $\delta$ ppm 41.8, 103.8 (d, $J=24.2 \mathrm{~Hz}$ ), 106.5 (d, $J=24.2 \mathrm{~Hz}$ ), 114.5, 120.9, 129.4, 129.6, $131.5(\mathrm{~d}, J=11 \mathrm{~Hz}), 138.2,160.4(\mathrm{~d}, J=13.2 \mathrm{~Hz}), 164.8(\mathrm{~d}, J=249 \mathrm{~Hz}), 165.7$; HPLC, RT= 1.09 min; HRMS calcd for $\mathrm{C}_{14} \mathrm{H}_{14} \mathrm{FN}_{2} \mathrm{O}_{2} 261.1034$, found 261.1034.

$N$-(4-(aminomethyl)phenyl)-1-hydroxy-2-naphtamide hydrochloride (40). White solid ( $\mathrm{m}=63$ mg, 99\% yield); mp: $277-278^{\circ} \mathrm{C}$ (dec.); ${ }^{1} \mathrm{H}$ NMR (DMSO $d_{6}, 300 \mathrm{MHz}$ ): $\delta$ ppm 4.02 (s, 2H), 7.46 (d, $1 \mathrm{H}, J=8.9 \mathrm{~Hz}$ ), $7.53(\mathrm{~d}, 2 \mathrm{H}, J=8.3 \mathrm{~Hz}), 7.59(\mathrm{~d}, 1 \mathrm{H}, J=7.5 \mathrm{~Hz}), 7.68(\mathrm{t}, 1 \mathrm{H}, J=7.5 \mathrm{~Hz}$ ), 7.80 (d, $2 \mathrm{H}, J=8.3 \mathrm{~Hz}$ ), $7.92(\mathrm{~d}, 1 \mathrm{H}, J=8.0 \mathrm{~Hz}), 8.22(\mathrm{~d}, 1 \mathrm{H}, J=8.9 \mathrm{~Hz}), 8.31(\mathrm{~d}, 1 \mathrm{H}, J=8.3 \mathrm{~Hz}), 8.48$ (bs, 3H), $10.43(\mathrm{~s}, 1 \mathrm{H}) ;{ }^{13} \mathrm{C}$ NMR (DMSO $d_{6}, 75 \mathrm{MHz}$ ): $\delta$ ppm 41.8, 107.5, 117.8, 122.1, 123.1, 
123.2, 124.6, 125.9, 127.5, 129.2, 129.4, 130.2, 136.0, 137.8, 160.0, 169.6; HPLC, RT= 1.45 min; MS (ESI+): m/z 294.1 [M+H+1] $]^{+}$HRMS calcd for $\mathrm{C}_{18} \mathrm{H}_{17} \mathrm{~N}_{2} \mathrm{O}_{2}$ 293.1290, found 293.1289.

$\mathrm{N}$-(4-(aminomethyl)phenyl)-2-hydroxy-1-naphtamide hydrochloride (41). White powder $(\mathrm{m}=$ $57 \mathrm{mg}, 97 \%$ yield); mp: $248-249^{\circ} \mathrm{C} ;{ }^{1} \mathrm{H}$ NMR (DMSO $\left.d_{6}, 300 \mathrm{MHz}\right): \delta$ ppm 3.98 (d, $2 \mathrm{H}, J=5.3$ Hz), $7.32(\mathrm{~m}, 2 \mathrm{H}), 7.45(\mathrm{~m}, 3 \mathrm{H}), 7.67(\mathrm{~d}, 1 \mathrm{H}, J=8.3 \mathrm{~Hz}), 7.84(\mathrm{~m}, 4 \mathrm{H}), 8.42(\mathrm{bs}, 3 \mathrm{H}), 10.22$ (bs, 1H), $10.43(\mathrm{~s}, 1 \mathrm{H}) ;{ }^{13} \mathrm{C}$ NMR (DMSO $d_{6}, 75 \mathrm{MHz}$ ): $\delta \mathrm{ppm} 41.9,118.4,119.1,122.9,123.2,126.9$, 127.3, 127.9, 128.6, 129.5, 130.1, 131.3, 139.7, 151.7, 165.8; HPLC, RT= $1.11 \mathrm{~min}$; MS (ESI+): m/z 294.1 [M+H+1] $]^{+}$; HRMS calcd for $\mathrm{C}_{18} \mathrm{H}_{17} \mathrm{~N}_{2} \mathrm{O}_{2}$ 293.1285, found 293.1293.

$\mathrm{N}$-(4-(aminomethyl)phenyl)-3-hydroxy-2-naphtamide hydrochloride (42). White powder (m= $40 \mathrm{mg}, 61 \%$ yield); mp: $299-300^{\circ} \mathrm{C}$ (dec.); ${ }^{1} \mathrm{H}$ NMR (DMSO $d_{6}, 400 \mathrm{MHz}$ ): $\delta \mathrm{ppm} 4.00$ (s, 2H), $7.37(\mathrm{~m}, 2 \mathrm{H}), 7.51(\mathrm{~m}, 3 \mathrm{H}), 7.76(\mathrm{~d}, 1 \mathrm{H}, J=8.3 \mathrm{~Hz}), 7.80(\mathrm{~d}, 2 \mathrm{H}, J=8.4 \mathrm{~Hz}), 7.94(\mathrm{~d}, 1 \mathrm{H}, J=8.3$ $\mathrm{Hz}), 8.35$ (bs, 3H), $8.53(\mathrm{~s}, 1 \mathrm{H}), 10.70(\mathrm{~s}, 1 \mathrm{H}), 11.39$ (bs, $1 \mathrm{H}) ;{ }^{13} \mathrm{C}$ NMR (DMSO $\left.d_{6}, 100 \mathrm{MHz}\right): \delta$ ppm 41.8, 110.6, 120.4, 121.8, 123.7, 125.8, 126.9, 128.1, 128.7, 129.4, 129.6, 130.6, 135.8, 138.7, 153.6, 165.6; HPLC, RT= $1.26 \mathrm{~min}$; HRMS calcd for $\mathrm{C}_{18} \mathrm{H}_{17} \mathrm{~N}_{2} \mathrm{O}_{2}$ 293.1285, found 293.1286.

$N$-(4-(aminomethyl)phenyl)-2-naphtamide hydrochloride (43). White powder ( $\mathrm{m}=26 \mathrm{mg}, 61 \%$ yield); mp: $285-286^{\circ} \mathrm{C}$ (dec.): ${ }^{1} \mathrm{H}$ NMR (DMSO d $6,500 \mathrm{MHz}$ ): $\delta$ ppm 4.00 (q, $2 \mathrm{H}, J=6.0 \mathrm{~Hz}$ ), 7.50 (d, $2 \mathrm{H}, J=8.5 \mathrm{~Hz}), 7.64(\mathrm{~m}, 2 \mathrm{H}), 7.88(\mathrm{~d}, 2 \mathrm{H}, J=8.5 \mathrm{~Hz}), 8.01(\mathrm{dd}, 1 \mathrm{H}, J=7.6 \mathrm{~Hz}, 1.4 \mathrm{~Hz}$ ), 8.05 (m, 2H), $8.10(\mathrm{dd}, 1 \mathrm{H}, J=7.3 \mathrm{~Hz}, 1.3 \mathrm{~Hz}), 8.47(\mathrm{bs}, 3 \mathrm{H}), 8.64(\mathrm{~s}, 1 \mathrm{H}), 10.63(\mathrm{~s}, 1 \mathrm{H}) ;{ }^{13} \mathrm{C}$ NMR (DMSO $d_{6}, 125$ MHz): $\delta$ ppm 41.9, 120.3, 124.5, 126.9, 127.7, 128.0, 128.1, 128.2, 129.0, 129.2, 129.5, 132.0, 132.1, 134.3, 139.4, 165.7; HPLC, RT= $1.21 \mathrm{~min}$; HRMS calcd for $\mathrm{C}_{18} \mathrm{H}_{17} \mathrm{~N}_{2} \mathrm{O}_{2}$ 277.1335, found 277.1326 . 
$\mathrm{N}$-[4-(aminomethyl)phenyl]-1H-indole-2-carboxamide (44). White solid ( $\mathrm{m}=40 \mathrm{mg}, 76 \%$ yield); mp: $291-292^{\circ} \mathrm{C}$ (dec.); ${ }^{1} \mathrm{H}$ NMR (DMSO d $d_{6}, 300 \mathrm{MHz}$ ): $\delta$ ppm 3.98 (q, $2 \mathrm{H}, J=5.7 \mathrm{~Hz}$ ), 7.07 $(\mathrm{t}, 1 \mathrm{H}, J=7.8 \mathrm{~Hz}), 7.22(\mathrm{t}, 1 \mathrm{H}, J=7.8 \mathrm{~Hz}), 7.47(\mathrm{~m}, 4 \mathrm{H}), 7.67(\mathrm{~d}, 1 \mathrm{H}, J=8.0 \mathrm{~Hz}), 7.87(\mathrm{~d}, 2 \mathrm{H}, J=$ $8.6 \mathrm{~Hz}$ ), 8.40 (bs, 3H), 10.47 (s, 1H), $11.88(\mathrm{~s}, 1 \mathrm{H}) ;{ }^{13} \mathrm{C}$ NMR (DMSO $d_{6}, 100 \mathrm{MHz}$ ): $\delta$ ppm 41.9, $104.4,112.4,119.9,120.0,121.8,123.9,127.0,128.9,129.5,131.4,136.8,139.2$, 159.7; HPLC, $\mathrm{RT}=1.82 \mathrm{~min} ; \mathrm{HRMS}$ calcd for $\mathrm{C}_{16} \mathrm{H}_{16} \mathrm{~N}_{3} \mathrm{O} 266.1288$, found 266.1284 .

$\mathrm{N}$-[4-(aminomethyl)phenyl]-4-oxo-1,4-dihydroquinoline-3-carboxamide (45). White solid (m= $65 \mathrm{mg}, 99 \%$ yield); mp: $287-289^{\circ} \mathrm{C}$ (dec.); ${ }^{1} \mathrm{H}$ NMR (DMSO $d_{6}, 400 \mathrm{MHz}$ ): $\delta$ ppm 3.96 (q, $2 \mathrm{H}, J=$ $5.5 \mathrm{~Hz}), 7.50(\mathrm{~d}, 2 \mathrm{H}, J=8.4 \mathrm{~Hz}), 7.53(\mathrm{td}, 1 \mathrm{H}, J=7.9 \mathrm{~Hz}, 1.3 \mathrm{~Hz}), 7.76(\mathrm{~d}, 2 \mathrm{H}, J=8.4 \mathrm{~Hz}), 7.79-$ $7.86(\mathrm{~m}, 2 \mathrm{H}), 8.31(\mathrm{~d}, 1 \mathrm{H}, J=7.9 \mathrm{~Hz}), 8.53(\mathrm{bs}, 3 \mathrm{H}), 8.82(\mathrm{~d}, 1 \mathrm{H}, J=6.7 \mathrm{~Hz}), 12.56(\mathrm{~s}, 1 \mathrm{H}), 13.62$ (d, $1 \mathrm{H}, J=6.4 \mathrm{~Hz}$ ); ${ }^{13} \mathrm{C}$ NMR (DMSO $d_{6}, 100 \mathrm{MHz}$ ): $\delta$ ppm 41.8, 110.3, 119.2, 119.5, 125.3, 125.4, 125.9, 128.9, 129.9, 133.0, 138.9, 139.1, 143.9, 163.0, 176.3; HPLC, RT= 1.04 min; HRMS calcd for $\mathrm{C}_{17} \mathrm{H}_{16} \mathrm{~N}_{3} \mathrm{O}_{2}$ 294.1237, found 294.1247.

$N$-(4-(aminomethyl)phenyl)-3-hydroxypyridine-2-carboxamide hydrochloride (46). Beige solid (m= $28 \mathrm{mg}, 44 \%$ yield); mp: $251-252^{\circ} \mathrm{C} ;{ }^{1} \mathrm{H}$ NMR (DMSO $\left.d_{6}, 300 \mathrm{MHz}\right): \delta$ ppm $4.00(\mathrm{q}, 2 \mathrm{H}, J=$ $5.4 \mathrm{~Hz}), 4.78(\mathrm{bs}, 3 \mathrm{H}), 7.50(\mathrm{~m}, 3 \mathrm{H}), 7.61(\mathrm{dd}, 1 \mathrm{H}, J=8.5 \mathrm{~Hz}, 4.3 \mathrm{~Hz}), 7.87(\mathrm{~d}, 2 \mathrm{H}, J=8.6 \mathrm{~Hz})$, 8.27 (dd, $1 \mathrm{H}, J=4.3 \mathrm{~Hz}, 1.1 \mathrm{~Hz}$ ), 8.35 (bs, $2 \mathrm{H}$ ), $10.99(\mathrm{~s}, 1 \mathrm{H}) ;{ }^{13} \mathrm{C}$ NMR (DMSO $d_{6}, 75 \mathrm{MHz}$ ): $\delta$ ppm 41.8, 121.3, 126.5, 129.4, 129.6, 130.2, 131.2, 13 7.3, 139.8, 157.6, 167.3; HPLC, RT= 0.95 min; HRMS calcd for $\mathrm{C}_{13} \mathrm{H}_{14} \mathrm{~N}_{3} \mathrm{O}_{2} 244.1081$, found 244.1102.

$N$-(4-(aminomethyl)phenyl)-6-methoxy-1-hydroxy-2-naphtamide hydrochloride (47). Beige solid (m= $65 \mathrm{mg}, 91 \%$ yield); mp: $256-257^{\circ} \mathrm{C}$ (dec.); ${ }^{1} \mathrm{H}$ NMR (DMSO $d_{6}, 300 \mathrm{MHz}$ ): $\delta$ ppm 3.91 (s, 3H), $4.02(\mathrm{~s}, 2 \mathrm{H}), 7.19(\mathrm{dd}, 1 \mathrm{H}, J=9.2,2.5 \mathrm{~Hz}), 7.35(\mathrm{~m}, 2 \mathrm{H}), 7.51(\mathrm{~d}, 2 \mathrm{H}, J=8.6 \mathrm{~Hz}), 7.77(\mathrm{~d}$, 
$2 \mathrm{H}, J=8.6 \mathrm{~Hz}$ ), $8.14(\mathrm{~d}, 1 \mathrm{H}, J=9.2 \mathrm{~Hz}), 8.20(\mathrm{~d}, 1 \mathrm{H}, J=9.2 \mathrm{~Hz}), 8.36(\mathrm{bs}, 3 \mathrm{H}), 10.55(\mathrm{bs}, 1 \mathrm{H})$, $14.00(\mathrm{~s}, 1 \mathrm{H}) ;{ }^{13} \mathrm{C}$ NMR (DMSO $\left.d_{6}, 75 \mathrm{MHz}\right): \delta \mathrm{ppm} 41.8,55.4,105.7,106.4,117.0,117.9,119.4$ 122.0, 123.9, 125.0, 129.4, 130.1, 137.9, 138.1, 159.9, 160.3, 169.7; HPLC, RT= 1.36 min; HRMS calcd for $\mathrm{C}_{19} \mathrm{H}_{19} \mathrm{~N}_{2} \mathrm{O}_{3} 323.1390$, found 323.1397.

$N$-(4-(aminomethyl)phenyl)-7-methoxy-1-hydroxy-2-naphtamide hydrochloride (48). White solid ( $m=55 \mathrm{mg}, 77 \%$ yield); mp: $250-251^{\circ} \mathrm{C} ;{ }^{1} \mathrm{H}$ NMR (DMSO $d_{6}, 400 \mathrm{MHz}$ ): $\delta$ ppm 3.91 (s, 3H), $4.02(\mathrm{q}, 2 \mathrm{H}, J=5.0 \mathrm{~Hz}), 7.32(\mathrm{dd}, 1 \mathrm{H}, J=8.9 \mathrm{~Hz}, 2.6 \mathrm{~Hz}), 7.42(\mathrm{~d}, 1 \mathrm{H}, J=8.8 \mathrm{~Hz}), 7.51(\mathrm{~d}, 2 \mathrm{H}, J=$ $8.6 \mathrm{~Hz}), 7.60(\mathrm{~d}, 1 \mathrm{H}, J=2.6 \mathrm{~Hz}), 7.79(\mathrm{~d}, 2 \mathrm{H}, J=8.6 \mathrm{~Hz}), 7.85(\mathrm{~d}, 1 \mathrm{H}, J=8.9 \mathrm{~Hz}), 8.02(\mathrm{~d}, 1 \mathrm{H}, J=$ $8.9 \mathrm{~Hz}$ ), 8.36 (bs, 3H), $10.59(\mathrm{~s}, 1 \mathrm{H}), 13.86(\mathrm{~s}, 1 \mathrm{H}) ;{ }^{13} \mathrm{C}$ NMR (DMSO $d_{6}, 100 \mathrm{MHz}$ ): $\delta$ ppm 41.8, $55.2,101.5,107.9,117.7,120.6,121.2,122.1,125.6,129.2,129.4,130.1,131.3,137.8,157.4$ 158.8, 169.7; HPLC, RT= 1.37 min; HRMS calcd for $\mathrm{C}_{19} \mathrm{H}_{19} \mathrm{~N}_{2} \mathrm{O}_{3} 323.1390$, found 323.1403.

N-(4-(aminomethyl)phenyl)-7-methyl-1-hydroxy-2-naphtamide hydrochloride (49). White solid (m= $53 \mathrm{mg}, 77 \%$ yield); mp: $276-278^{\circ} \mathrm{C}$ (dec.); ${ }^{1} \mathrm{H}$ NMR (DMSO $d_{6}, 500 \mathrm{MHz}$ ): $\delta$ ppm 3.34 (s, 3H), $4.01(\mathrm{~s}, 2 \mathrm{H}), 7.40(\mathrm{~d}, 1 \mathrm{H}, J=8.7 \mathrm{~Hz}), 7.51(\mathrm{~m}, 3 \mathrm{H}), 7.80(\mathrm{~m}, 3 \mathrm{H}), 8.08(\mathrm{~s}, 1 \mathrm{H}), 8.12(\mathrm{~d}$, $1 \mathrm{H}, J=8.7 \mathrm{~Hz}$ ), $8.44(\mathrm{bs}, 3 \mathrm{H}), 10.62(\mathrm{~s}, 1 \mathrm{H}), 13.94(\mathrm{~s}, 1 \mathrm{H}) ;{ }^{13} \mathrm{C}$ NMR (DMSO $d_{6}, 125 \mathrm{MHz}$ ): $\delta \mathrm{ppm}$ $21.4,41.8,107.5,117.6,122.0,122.1,122.2,124.7,127.4,129.4,130.2,131.2,134.2,135.4$ 137.8, 159.6, 169.7; HPLC, RT= $1.43 \mathrm{~min}$; HRMS calcd for $\mathrm{C}_{19} \mathrm{H}_{19} \mathrm{~N}_{2} \mathrm{O}_{2}$ 307.1441, found 307.1452.

N-(4-(aminomethyl)phenyl)-7-chloro-1-hydroxy-2-naphtamide hydrochloride (50). White solid (m= $55 \mathrm{mg}, 76 \%$ ); mp: $277-278^{\circ} \mathrm{C} ;{ }^{1} \mathrm{H}$ NMR (DMSO $\left.d_{6}, 500 \mathrm{MHz}\right): \delta \mathrm{ppm} 4.02(\mathrm{q}, 2 \mathrm{H}, J=$ $5.6 \mathrm{~Hz}$ ), $7.53(\mathrm{~m}, 3 \mathrm{H}), 7.70(\mathrm{dd}, 1 \mathrm{H}, J=8.8 \mathrm{~Hz}, 2.2 \mathrm{~Hz}), 7.79(\mathrm{~d}, 2 \mathrm{H}, J=8.6 \mathrm{~Hz}), 7.99(\mathrm{~d}, 1 \mathrm{H}, J=$

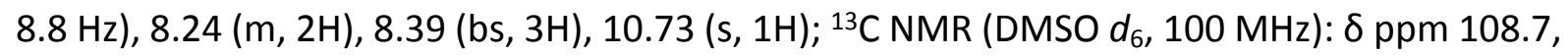


$117.8,121.8,122.2,123.8,125.4,129.5,129.6,129.9,130.4,130.8,134.4,137.7,158.8,169.3$;

HPLC, RT= 1.49 min; HRMS calcd for $\mathrm{C}_{18} \mathrm{H}_{16} \mathrm{~N}_{2} \mathrm{O}_{2} \mathrm{Cl} 327.0895$, found 327.0890.

$N$-(4-(aminomethyl)phenyl)-6,7-dimethoxy-1-hydroxy-2-naphtamide hydrochloride

(51).

White solid ( $\mathrm{m}=62 \mathrm{mg}, 80 \%$ ); $\mathrm{mp}: 289-291^{\circ} \mathrm{C}$ (dec.); ${ }^{1} \mathrm{H}$ NMR (DMSO $d_{6}, 400 \mathrm{MHz}$ ): $\delta \mathrm{ppm}$ $3.90(\mathrm{~s}, 3 \mathrm{H}), 3.92(\mathrm{~s}, 3 \mathrm{H}), 4.01(\mathrm{q}, 2 \mathrm{H}, J=6.0 \mathrm{~Hz}), 7.31(\mathrm{~d}, 1 \mathrm{H}, J=8.8 \mathrm{~Hz}), 7.33(\mathrm{~s}, 1 \mathrm{H}), 7.51(\mathrm{~d}$, $2 \mathrm{H}, J=8.6 \mathrm{~Hz}), 7.55(\mathrm{~s}, 1 \mathrm{H}), 7.79(\mathrm{~d}, 2 \mathrm{H}, J=8.6 \mathrm{~Hz}), 8.03(\mathrm{~d}, 1 \mathrm{H}, J=8.8 \mathrm{~Hz}), 8.45(\mathrm{bs}, 3 \mathrm{H})$, $10.53(\mathrm{~s}, 1 \mathrm{H}), 13.85$ (s, 1H); ${ }^{13} \mathrm{C}$ NMR (DMSO d, $100 \mathrm{MHz}$ ): $\delta$ ppm 55.4, 55.6, 66.3, 101.8, $106.1,106.7,116.6,119.2,121.4,121.9,129.4,130.0,132.5,137.9,149.0,151.6,158.8$, 169.8; HPLC, RT= 2.28 min; HRMS calcd for $\mathrm{C}_{20} \mathrm{H}_{21} \mathrm{~N}_{2} \mathrm{O}_{4}$ 353.1496, found 353.1496.

1-Hydroxy-N-piperidin-4-yl-2-naphthamide (53). White solid ( $m=43 \mathrm{mg}, 70 \%$ yield); mp: 279-280 ${ }^{\circ}$; ${ }^{1} \mathrm{H}$ NMR (DMSO $\left.d_{6}, 400 \mathrm{MHz}\right): \delta$ ppm 1.89-2.02 (m, 4H), $3.02(\mathrm{~m}, 2 \mathrm{H}), 3.33(\mathrm{~d}, 2 \mathrm{H}$, $J=12.8 \mathrm{~Hz}), 4.19(\mathrm{~m}, 1 \mathrm{H}), 7.37(\mathrm{~d}, 1 \mathrm{H}, J=8.8 \mathrm{~Hz}), 7.55(\mathrm{td}, 1 \mathrm{H}, J=8.1 \mathrm{~Hz}, 1.1 \mathrm{~Hz}), 7.63(\mathrm{td}, 1 \mathrm{H}$, $J=8.1 \mathrm{~Hz}, 1.2 \mathrm{~Hz}), 7.87(\mathrm{~d}, 1 \mathrm{H}, J=8.1 \mathrm{~Hz}), 8.03(\mathrm{~d}, 1 \mathrm{H}, J=8.8 \mathrm{~Hz}), 8.25(\mathrm{~d}, 1 \mathrm{H}, J=8.1 \mathrm{~Hz}), 8.98$ (d, $1 \mathrm{H}, J=8.1 \mathrm{~Hz}$ ), 9.08 (bs, 2H), $14.50\left(\mathrm{~s}, 1 \mathrm{H}\right.$ ); ${ }^{13} \mathrm{C}$ NMR (DMSO d, $100 \mathrm{MHz}$ ): $\delta$ ppm 27.9, $44.5,66.3,106.9,117.4,122.9,123.0,124.6,125.7,127.4,128.9,135.8,159.7,170.1 ;$ HPLC, $\mathrm{RT}=1.28 \mathrm{~min} ; \mathrm{HRMS}$ calcd for $\mathrm{C}_{16} \mathrm{H}_{19} \mathrm{~N}_{2} \mathrm{O}_{2} 271.1441$, found 271.1439.

\section{Enzymes and chemicals}

KLK6 was purchased from R\&D Systems ${ }^{\circledR}$ as pro-KLK6. Activation of KLK6 is performed in 50 $\mathrm{mM}$ Tris, $0.05 \%(\mathrm{w} / \mathrm{v})$ Brij-35, $\mathrm{pH}$ 8.0. The activation reaction is initiated by lysylendopeptidase at $2.5 \mathrm{mU} \cdot \mathrm{mL}^{-1}$ (Wako Bioproducts ${ }^{\circledR}$ ). The activation reaction is stopped by diluting KLK6 to $0.5 \mu \mathrm{g} . \mathrm{mL}^{-1}$ in assay buffer (50 mM Tris, $1 \mathrm{M}$ Citrate, 0.05\% (w/v)Brij-35, pH 7.4) to obtain an active KLK6 stock. KLK1 was purchased from R \& D Systems ${ }^{\circledR}$ as pro-KLK1. 
Activation of KLK1 is performed in $50 \mathrm{mM}$ Tris- $\mathrm{HCl}, 10 \mathrm{mM} \mathrm{CaCl}_{2}, 150 \mathrm{mM} \mathrm{NaCl}, 0.05 \%$ Brij-35, $\mathrm{pH}$ 7.5. The activation reaction is initiated by bacterial thermolysin at $0.4 \mu \mathrm{g} \cdot \mathrm{mL}^{-1}$ (SigmaAldrich $^{\circledR}$ ) and stopped by addition of 100 mM EDTA (Sigma-Aldrich ${ }^{\circledR}$ ) to obtain an active KLK1 stock at the same concentration of $100 \mu \mathrm{g} \cdot \mathrm{mL}^{-1}$. Plasmin (Sigma-Aldrich ${ }^{\circledR}$ ) and Caspase-2, Caspase-3, Caspase-6 (Enzo Life Sciences ${ }^{\circledR}$ ) were purchased in mature and active form. All enzyme stocks were stored at $-20^{\circ}$ C. KLK4, KLK5, KLK7, KLK8, KLK11, KLK13; thrombin, cathepsin L, matriptase, trypsin, trypsin-3 and tPA were purchased from R\&D Systems ${ }^{\circledR}$ as proenzymes (KLK4, KLK7, KLK8, KLK11, KLK13) or as mature and active forms (KLK5, thrombin, cathepsin L, matriptase, trypsin-3, tPA). Activation of KLK4, KLK7, KLK8, KLK11 and KLK13 are performed in optimized buffers. The activation reactions for KLK4, KLK7 and KLK11 are initiated bacterial thermolysin at $0.4 \mu \mathrm{g} \cdot \mathrm{mL}^{-1}$ (Sigma-Aldrich ${ }^{\circledR}$ ) and stopped by addition of 100 mM EDTA (Sigma-Aldrich ${ }^{\circledR}$ ) to obtain active stocks. All enzyme stocks were stored at $-20^{\circ} \mathrm{C} . \mathrm{H}-$ PFR-AMC (KLK1), Boc-VPR-AMC (KLK4, KLK5, KLK8, KLK13, KLK14, Thrombin), Boc-QAR-AMC (KLK6, KLK11, Matriptase, Trypsin, Trypsin-3, Plasmin), Ac-VDVAD-AMC (Caspase-2), Ac-DEVDAMC (Caspase-3), Ac-VEID-AMC (Caspase-6), Z-LR-AMC (Cathepsin L), Z-GGR-AMC (tPA) substrates were purchased from Bachem ${ }^{\circledR}$. MeO-Suc-RPY-AMC (KLK7) substrate was purchased from AAT Bioquest ${ }^{\circledR}$.

\section{Kinetics assays}

Compounds were screened on KLK6, KLK1 and plasmin using a using a BMG Fluostar microplate reader (black 96-well microplates). The proteases are preincubated for 15 minutes with each compound $(10 \mu \mathrm{M}$ and $50 \mu \mathrm{M})$ or with DMSO $(<2 \%$, negative control) in a total volume of $100 \mu \mathrm{l}$ of $50 \mathrm{mM}$ Tris buffer, $1 \mathrm{M}$ citrate, $0.05 \% \mathrm{Brij}-35, \mathrm{pH} 7,37^{\circ} \mathrm{C}$. The reaction is triggered by adding the Boc-QAR-AMC (KLK6, plasmin) or H-PFR-AMC (KLK1) fluorogenic 
substrate $(100 \mu \mathrm{M})$ and followed for 30 minutes at $37^{\circ} \mathrm{C}$. The release of the $\mathrm{AMC}$ fluorescent group is detected using the following wavelengths: $\lambda_{\mathrm{ex}}=360 \mathrm{~nm}$ for the excitation and $\lambda_{\mathrm{em}}=$ $460 \mathrm{~nm}$ for the measurement of the emission. The percent inhibition is calculated from equation 1 where $V_{0}$ is the initial rate of the DMSO control, the initial rate in the presence of the inhibitor Vi.

$$
\left.\% \text { Inhibition }=\left(1-\left(V_{i} / V_{0}\right)\right) * 100\right)(\text { Eq. } 1)
$$

The selected compounds are those for which the inhibition is greater than $50 \%$ at a concentration of $10 \mu \mathrm{M}$ then the $\mathrm{IC}_{50}$ is determined. The inhibitory effect of the compound (\%) as a function of its concentration generally follows the Eq. 2 which results in a hyperbole or a sigmoid. The equation is entered in the Kaleidagraph ${ }^{\circledR} 4.5$ software for curve fitting $f([I])=\%$ Inhibition, where $[I]$ is the inhibitor concentration. The concentration ranges of inhibitor were adjusted to inhibitory potency as detected in preliminary screening tests, [I] was from $0.1 \mu \mathrm{M}$ to $100 \mu \mathrm{M}$.

The inhibitory activity of compounds was expressed as $I C_{50}$ (inhibitor concentrations giving $50 \%$ inhibition). The values of $I C_{50}$ were calculated by fitting the experimental data to the Equation $2 \mathrm{a}$ and $2 \mathrm{~b}$ :

$\%$ Inhibition $=100 \times\left(1-\mathrm{V}_{\mathrm{i}} / \mathrm{V}_{0}\right)=100[\mathrm{I}]_{0} /\left(\mathrm{IC} \mathrm{C}_{50}+[\mathrm{I}]_{0}\right),($ Eq 2a)

$\%$ Inhibition $=100[\mathrm{I}]_{0}{ }^{\mathrm{nH}} /\left(\mathrm{IC}_{50}{ }^{\mathrm{nH}}+[\mathrm{I}]_{0}{ }^{\mathrm{nH}}\right)$, where $\mathrm{n}_{\mathrm{H}}$ is the Hill number. (Eq $\left.2 \mathrm{~b}\right)$

Reversibility was analysed by diluting the reaction mixtures (dilution factor of 100) after 15 and 60 min preincubation of the enzyme with inhibitor. Aliquots of reaction mixtures (2.5 $\mu \mathrm{L}$ ) were added to $97.5 \mu \mathrm{L}$ of buffer containing the fluorogenic substrate (experimental conditions identical to the routine protocol used for a given enzyme). The mechanism of inhibition was determined by varying substrate and inhibitor concentrations, the type of inhibition and inhibition parameter (Ki) are determined by Dixon's plots. 


\section{Selectivity profiling}

Hit compounds were screened on the selected group of CNS proteases using optimized concentrations and buffers (KLK4 9.6 nM; KLK5 0.85 nM; KLK7 19 nM; KLK8 0.88 nM; KLK11 67 nM; KLK13 0.2 nM; KLK14 0.6 nM; Caspase-2 0.2 nM; Caspase-3 0.1 nM; Caspase-6 68.5 mU. $\mathrm{LL}^{-1}$; Cathepsin L 0.12 nM; Matriptase $0.69 \mathrm{nM}$; Thrombin 25 pM; tPA 6.7 nM; Trypsin 0.63 pM ; Trypsin-3 0.8 pM ;Plasmin $3 \mathrm{nM})$. The reaction is triggered by the appropriate substrate at the optimized concentration (H-PFR-AMC $100 \mu \mathrm{M}$; Boc-VPR-AMC $100 \mu \mathrm{M}$; Boc-QAR-AMC

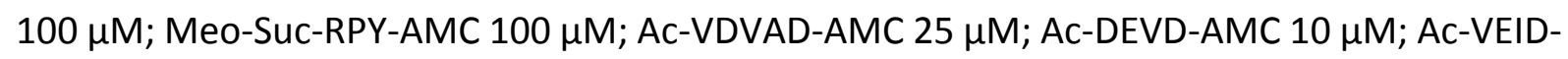
AMC $100 \mu \mathrm{M}$; Z-LR-AMC $50 \mu \mathrm{M}$; Z-GGR-AMC $100 \mu \mathrm{M}$ ) and followed for 30 minutes at $37^{\circ} \mathrm{C}$. Percentages of inhibition at $10 \mu \mathrm{M}$ of each compound are determined as described in previous paragraph. Results are given from 3 independent experiments with a standard error below $10 \%$.

\section{Molecular docking}

Molecular docking experiments were conducted to propose interaction models of the hit para-aminobenzyl derivatives $\mathbf{3 2}$ and $\mathbf{4 2}$ with KLK6. The protonation states of the ligands were calculated using MarvinSketch ${ }^{\circledR}$ at $\mathrm{pH}=7$. The major microspecy described the primary amine function charged, while the rest of the molecules was neutral (protonated alcohol function). The 3D conformations of both ligands were generated by MarvinSketch ${ }^{\circledR}$. The structure of the target was retrieved from the Protein Data Bank, and chose due to the presence of an orthosteric inhibitor similar in structure to the para-aminobenzyl derivatives in order to shape the binding pocket to these two compounds (PDB id: 4D8N ${ }^{33,45}$ ). The protonation state of the target was predicted with Propka. ${ }^{46}$ The catalytic histidine was found charged and protonated 
on both nitrogens, while other residues and termini were found in their canonical state at $\mathrm{pH}$ 7. The ligands and target were prepared using Autodock Tools $4{ }^{47}$ before flexible molecular docking with Autodock Vina. ${ }^{48}$ Q192 and S195 side chains were found in different orientations in other KLK6 structures. These two residues were set flexible in the molecular docking routine in order to increase the reliability of the results. Including this protein flexibility, the number of degrees of freedom (dof) was still in an acceptable range for Vina (10 dof, while Vina is designed to converge properly until 12 dof). The box was centered near the geometrical center of the S1 binding pocket (residue: H57, D189 to S195, S214 to N217, C220), with a final size of $18 \times 19 \times 18 \AA^{3}$ which largely included S1, S1', S2 and S2'. 20 poses were asked with an exhaustiveness of 128 . The poses were then re-scored using Convex-PL ${ }^{49}$ and the best poses according to this new scoring function of both compounds into KLK6 were further analyzed. The coordinate files of both poses are available in the online version.

\section{Neuronal cytotoxicity of hit compounds}

All animals were ethically maintained and used in compliance with the European Policy on Ethics. Cortices and striatum were microdissected from E14 embryos of Swiss mice (Janvier, Labs Le Genest Saint Isle, France) in D-PBS supplemented with $0.1 \%(w / w)$ glucose (ThermoFisher Scientific; 15023-021). Dissected structures were digested with trypsin/EDTA (ThermoFisher Scientific; R001100) for 15 minutes at room temperature. After trypsin inactivation with $10 \%$ (v/v) fetal bovine serum (10500056; ThermoFisher Scientific), structures were mechanically dissociated with a pipette in Neurobasal media (ThermoFisher Scientific; 2110349) supplemented with DNAse I (ThermoFisher Scientific; EN0525), B27 (ThermoFisher Scientific; 17504-044); L-Glutamine (ThermoFisher Scientific; 25030-024), Penicillin/Streptomysin (ThermoFisher Scientific, 1540-122). Cortical and striatal cells were 
then seeded at the density of 100000 cells/well in sterile transparent 96 well plates previously coated. Cells are cultured for 7 days at $37^{\circ} \mathrm{C}$ in a $5 \% \mathrm{CO}_{2}$ atmosphere. Cells were treated for 24 hours either with inhibitors at different concentrations $(10,25,50$ or $100 \mu \mathrm{M})$ or with the vehicle DMSO 1\% (negative control, vehicle) or with rotenone $50 \mu \mathrm{M}$ (positive control). The treatment of primary cultures of neurons by rotenone is a standard compound used to induce neuronal death. Medium is then replaced with $50 \mu \mathrm{L}$ of $\mathrm{XTT}\left(0.3 \mathrm{mg} \cdot \mathrm{mL}^{-1}\right)$ for 3 hours in order to carry out the cell viability test (Merck; 11465015001). XTT is a derivative of tetrazolium salt whose reduction by mitochondrial dehydrogenase viable cells shows a yellow-orange coloring. The activity of the mitochondria is determined by measuring the absorbance at 485 $\mathrm{nm}$. The percentage of cell survival is calculated by the ratio of the absorbance in the presence of the inhibitor to the negative control condition (DMSO 1\%). Statistical analyses of differences between treatments were assessed by a Kruskall-Wallis test using GraphPad Prism 7.03. For all analysis * $p$-value $<0.05 ; * *$-value $<0.01 ; * *$-value $<0.001$

\section{Evaluation of the effect of compounds on oligodendrocyte differentiation}

B104 cell culture

B104 cells were cultured in flasks (TPP) containing DMEM (Gibco) supplemented with 1\% penicillin-streptomycin (Gibco), 1\% Non-Essential Amino Acids Solution (Gibco) and 10\% Fetal Bovine Serum (FBS; Gibco) and passaged every week using Trypsin 0.25\% (Gibco; 25200056). This medium was changed after 4 days for N1 medium w/o biotin. This B104-conditioned medium containing growth factors was collected after 3 days and used to prepare N1B104 medium. 
CG4 cell line culture

CG4 cells were cultured in culture flasks (TPP) coated with $0.01 \%$ Poly-L-Ornithine (Sigma) with filtered N1B104 medium to ensure proliferation. Cells were passaged with Trypsin $0.05 \%$ (Gibco) when reaching $60-70 \%$ confluence. ${ }^{52}$ The CG4 line used in this study expressed the fluorescent reporters GFP at all developmental stages of the oligodendroglial cell lineage and mCherry only in differentiated and mature oligodendrocytes (Deboux et al. in preparation). For differentiation assay, CG4 cells were seeded in N1B104 medium in 96 well plates (Nunc) at the density of 6500 cell/cm2 for few hours. Cells were then switched in a differentiation medium (DMEM/F12 1:1 (Gibco) supplemented with 2\% B27 (Gibco); 1\% laminin (Sigma) and $1 \% \mathrm{~N} 1$ biotin) with or without the compounds. The 9-cis-retinoic acid at $1 \mu \mathrm{M}$ (Sigma) was as positive control. Cells were differentiated for 5 days before image acquisition and quantification on an Arrayscan XTI System (Thermo Scientific).

\section{Oligodendrocyte precursor cell (OPCS) primary cell cultures}

Primary OPCs cultured were derived from Wistar rats' cerebral cortices at $\mathrm{P} 1$, as previously described. ${ }^{50}$ Briefly, the cerebral cortices were dissected and the meninges were removed in DME, $1 \%$ penicillin-streptomycin and $1 \%$ MEM NEAA. Tissues were dissociated enzymatically using trypsin-EDTA solution for $10 \mathrm{~min}$ at $37^{\circ} \mathrm{C}$. Cell suspension was filtered with $70 \mu \mathrm{m}$ nylon cell strainer, centrifuged at $1000 \mathrm{rpm}$ for $10 \mathrm{~min}$ and resuspended in an appropriate volume of DMEM/10\% FBS for seeding (10 ml per flask/ 2 brains in each) in culture flasks coated with $0.01 \%$ poly-L-ornithine and incubated at $5 \% \mathrm{CO}_{2}$ and $37^{\circ} \mathrm{C}$ for approximately two weeks. The medium was changed at day 7 . After $14 \mathrm{DIV}$, cells were shaken for $2 \mathrm{~h}$ at $250 \mathrm{rpm}$ to remove microglia ${ }^{51}$. An additional shaking is performed overnight at $250 \mathrm{rpm}$ to detach and collect OPCs. Collected OPCs were plated on Poly-Ornithine coated 24-well plates, at a density of 25 
000 cells/well. OPCs were kept in proliferation medium containing DMEM/F12 (1:1), supplemented with $2 \%$ B27 (all purchased from Gibco), FGF and PDGF (10 ng/ml each) to allow adhesion. The medium is then changed for a differentiation medium with or without the compounds. As for the CG4 cultures, 9-cis-retinoic acid at $1 \mu \mathrm{M}$ was used as a positive control. Cells were kept in differentiation medium for 5 days, before image acquisition and quantification on an Arrayscan XTI System (Thermo Scientific).

\section{Immunostaining}

Cells were fixed with $2 \%$ paraformaldehyde (Electron Microscopy) for $5 \mathrm{mn}$ at room temperature, washed with PBS $1 \mathrm{X}$ and stored at $4^{\circ} \mathrm{C}$ prior to staining. They were incubated for 1 hour at RT in 4\% BSA (Sigma); 1X PBS, 0.1\% Triton X-100 and primary antibodies. They were next rinsed three times with PBS $1 \mathrm{X}$ and incubated for $45 \mathrm{mn}$ at RT in $4 \%$ BSA in $1 \mathrm{X}$ PBS, 1 $\mu \mathrm{g} / \mathrm{ml}$ Hoechst dye (Sigma, B2261) and secondary antibodies. After incubation, plates were washed three times with PBS 1X. Image acquisitions and quantification were performed as described above.

The line used is a rat oligodendrocyte precursor (CG4) CG4 cell line, stably transduced with the GFP reporter gene under the control of the CMV promoter and mCherry under the control of a differentiated oligodendrocyte specific promoter. The mCherry marker is only expressed at the differentiated oligodendrocyte stage and thus makes it possible to test compounds capable of inducing differentiation of OPCs. The cells are cultured in the proliferation medium described by Louis et al. ${ }^{52}$ at the time of their enumeration, then in a medium of differentiation (DMEM / F12, B27, N1, biotin, laminin). The cells are treated with different inhibitor concentrations for $72 \mathrm{~h}$ in 96 -well plates and then screened using an automated inverted microscope. The experimental controls used are a basal control containing only the 
differentiation medium and a positive control, 9-cis-retinoic acid, known for its effect in inducing differentiation of OPCs. ${ }^{53}$ To evaluate the effects of the compounds on OPC differentiation, we quantified the number of mCherry+ and GFP+ cells in each experimental condition relatively to the basal control. An effect in favor of differentiation is reflected in a significant increase in the number of mCherry+ cells, in contrast to an effect to the detriment of differentiation. The results are analyzed using the Mann-Whitney statistical test.

\section{Anti-inflammatory potential}

The impact of compounds on microglial activation and pro-inflammatory cytokines was assessed in purified primary microglial cultures isolated from newborn rat brain, as previously described. ${ }^{36}$ All animals used were handled in accordance with European standards for ethics and animal welfare. The new born WISTAR rats (Janvier Labs ${ }^{\circledR}$, Le Genest Saint Isle, France) at stage P1 are sacrificed by decapitation. After removal of the meninges, the cortical structures are removed in DMEM medium containing $1 \%$ of penicillin / streptomycin mix (Thermofisher ${ }^{\circledR}, 15070063$ ) and $1 \%$ of non-essential amino acids (MEM NEAA, Thermofisher ${ }^{\circledR}, 11140050$ ). Tissues are enzymatically dissociated by the addition of trypsin-EDTA $\left(\mathrm{Gibco}^{\circledR}, 25200056\right)$ for 10 minutes at $37^{\circ} \mathrm{C}$. Cell suspension is then passed through a nylon filter $70 \mu \mathrm{m}$ in diameter, centrifuged at $1000 \mathrm{rpm}$ for 10 minutes then resuspended in a volume of $10 \mathrm{~mL}$ of DMEM medium supplemented with $10 \%$ FCS (Thermofisher Scientific ${ }^{\oplus}, 10500056$ ) in a flask previously coated with $0.01 \%$ poly-L-ornithine (SigmaAldrich $\left.{ }^{\circledast}, \mathrm{P} 4957\right)$. Cells are cultured for two weeks at $37^{\circ} \mathrm{C}$ in a humid atmosphere $\left(5 \% \mathrm{CO}_{2}\right)$ with a change of medium on the seventh day. At the end of this period, the cells are stirred for 2 hours at 250 rpm to detach and recover the microglia. Cells are inoculated into sterile transparent 96-well FALCON ${ }^{\circledR}$ plates at a density of 50,000 cells / well in DMEM / F12 medium supplemented with $1 \%$ N2 mix, then cultured for 24 hours at $37^{\circ} \mathrm{C}$ in a humid atmosphere $\left(5 \% \mathrm{CO}_{2}\right)$. The microglia is treated with lipopolysaccharide (LPS, $10 \mathrm{ng} \cdot \mathrm{mL}^{-1}$, Sigma Aldrich ${ }^{\circledR}$ ) to create an inflammatory environment to be 
activated. Concomitantly, cells are treated either with inhibitors at different concentrations defined according to the $\mathrm{IC}_{50}$ values $(0.5-10 \mu \mathrm{M})$, or with $1 \%$ DMSO (negative control), or with $100 \mathrm{nM}$ dexamethasone (positive anti-inflammatory control, Sigma -Aldrich ${ }^{\circledast}$ D4902) for 3 hours at $37^{\circ} \mathrm{C}$ in a humid atmosphere $\left(5 \% \mathrm{CO}_{2}\right)$. At the end of this incubation, supernatants are recovered for assays of pro-inflammatory cytokines TNF- $\alpha$ and IL1- $\beta$ by ELISA (Rat TNF- $\alpha$ ELISA MAXTM Deluxe Set \# 438204, rat IL1- $\beta$ ELISA kit ab100768) 


\section{Associated content}

The supporting information is available free of charge on the ACS Publications website.

Supplementary figures: compounds synthesis and characterization data, Dixon plot of compounds $\mathbf{3 7}$ and $\mathbf{4 7}$ towards KLK6 (Figure S1), Structure of synthesized compounds (Table S1), comparative table of ADME and pharmacological parameters for hit compounds 32 and

\section{2 (Table S2).}

Models of compounds $\mathbf{3 2}$ and $\mathbf{4 2}$ docked on 4D8N KLK6 pdb files. (PDB)

Molecular formula strings of compounds described in this study (CSV)

\section{Author information}

\section{Corresponding authors}

Email: Chahrazade.el_amri@sorbonne-universite.fr

\section{Address}

Sorbonne Université, Faculty of Sciences and Engineering, IBPS, UMR 8256 CNRS-UPMC, ERL INSERM U1164, Biological Adaptation and Ageing, F-75252 Paris, France. Paris, France

\section{Author contributions}

The research was designed by CE, NM, BNO. Chemical synthesis was performed by NM. Enzymology assays were performed by SAA, NC and FS, biological with neural cells, OPCs and microglial by SAA and CD. Docking models were determined by ML. ED and SB contributed to experiments on primary cultures of neural cells. Data analysis and manuscript preparation were done by $\mathrm{CE}, \mathrm{NM}$ and $\mathrm{BNO}$. All the authors have given approval the final version of the manuscript.

Notes

The authors declare no competing financial interest. 


\section{Acknowledgements:}

The authors are grateful to Sorbonne Université, Université of Montpellier, Institut National pour la Recherche Médicale (INSERM), Centre National de la Recherche Scientifique (CNRS) as well as the SATT Lutech for research funding. The authors wish to thank Dr David Akbar (ICM Cell Culture Facility, CELIS) for his advice and technical assistance on fluorescence imaging and quantitative analysis. This study was supported by the Investissements d'Avenir ANR-10IAIHU-06 (IHU-A-ICM) and ANR-11-INBS-0011 (NeurATRIS) (to B.N-O.) We also thank the French Ministry of Research and Education for S A and F. S PhD fellowships.

\section{$\underline{\text { Abbreviations used }}$}

ADMET, Absorption Diffusion Metabolism, Elimination and Toxicity; CNS, central nervous system; DMEM, Dulbecco's modified Eagle's medium; DMSO, dimethyl sulfoxide; EDCI, N-(3dimethylaminopropyl)- $N^{\prime}$-ethylcarbodiimide hydrochloride; IL1 $\beta$ : interleukin $1 \beta$; KLK, tissue kallikreins; KLK1, kallikrein-related peptidase 1; KLK6, kallikrein-related peptidase 6; LPS, lipopolysaccharide; MBP, myelin basic protein; MS, multiple sclerosis; OPC, oligodendrocyte precurcor cell; PAR, Protease-Activated receptors; TNF $\beta$ : tumor necrosis factor. 


\section{References}

1. Lassmann, H. Multiple Sclerosis Pathology. Cold Spring Harb Perspect Med 2018, 8, 115.

2. Friese, M. A.; Schattling, B.; Fugger, L. Mechanisms of neurodegeneration and axonal dysfunction in multiple sclerosis. Nat Rev Neurol 2014, 10, 225-238.

3. Kuhlmann, T.; Miron, V.; Cui, Q.; Wegner, C.; Antel, J.; Bruck, W. Differentiation block of oligodendroglial progenitor cells as a cause for remyelination failure in chronic multiple sclerosis. Brain 2008, 131, 1749-1758.

4. Bove, R. M.; Green, A. J. Remyelinating Pharmacotherapies in Multiple Sclerosis. Neurotherapeutics 2017, 14, 894-904.

5. Cole, K. L. H.; Early, J. J.; Lyons, D. A. Drug discovery for remyelination and treatment of MS. Glia 2017, 65, 1565-1589.

6. Franklin, R. J. M.; Ffrench-Constant, C. Regenerating CNS myelin - from mechanisms to experimental medicines. Nat Rev Neurosci 2017, 18, 753-769.

7. Coetzee, T.; Thompson, A. J. Unified understanding of MS course is required for drug development. Nat Rev Neurol 2018, 14, 191-192.

8. Cunniffe, N.; Coles, A. Promoting remyelination in multiple sclerosis. I Neurol 2021, $268,30-44$

9. Murakami, K.; Jiang, Y. P.; Tanaka, T.; Bando, Y.; Mitrovic, B.; Yoshida, S. In vivo analysis of kallikrein-related peptidase 6 (KLK6) function in oligodendrocyte development and the expression of myelin proteins. Neuroscience 2013, 236, 1-11.

10. Bando, Y.; Ito, S.; Nagai, Y.; Terayama, R.; Kishibe, M.; Jiang, Y. P.; Mitrovic, B.; Takahashi, T.; Yoshida, S. Implications of protease $\mathrm{M} /$ neurosin in myelination during experimental demyelination and remyelination. Neurosci Lett 2006, 405, 175-180. 
11. Scarisbrick, I. A.; Isackson, P. J.; Ciric, B.; Windebank, A. J.; Rodriguez, M. MSP, a trypsinlike serine protease, is abundantly expressed in the human nervous system. J Comp Neurol 2001, 431, 347-361.

12. Bando, Y.; Hagiwara, Y.; Suzuki, Y.; Yoshida, K.; Aburakawa, Y.; Kimura, T.; Murakami, C.; Ono, M.; Tanaka, T.; Jiang, Y. P.; Mitrovi, B.; Bochimoto, H.; Yahara, O.; Yoshida, S. Kallikrein 6 secreted by oligodendrocytes regulates the progression of experimental autoimmune encephalomyelitis. Glia 2018, 66, 359-378.

13. Burda, J. E.; Radulovic, M.; Yoon, H.; Scarisbrick, I. A. Critical role for PAR1 in kallikrein 6-mediated oligodendrogliopathy. Glia 2013, 61, 1456-1470.

14. Yoon, H.; Radulovic, M.; Scarisbrick, I. A. Kallikrein-related peptidase 6 orchestrates astrocyte form and function through proteinase activated receptor-dependent mechanisms. Biol Chem 2018, 399, 1041-1052.

15. Yoon, H.; Radulovic, M.; Walters, G.; Paulsen, A. R.; Drucker, K.; Starski, P.; Wu, J.; Fairlie, D. P.; Scarisbrick, I. A. Protease activated receptor 2 controls myelin development, resiliency and repair. Glia 2017, 65, 2070-2086.

16. Radulovic, M.; Yoon, H.; Wu, J.; Mustafa, K.; Scarisbrick, I. A. Targeting the thrombin receptor modulates inflammation and astrogliosis to improve recovery after spinal cord injury. Neurobiol Dis 2016, 93, 226-242.

17. Panos, M.; Christophi, G. P.; Rodriguez, M.; Scarisbrick, I. A. Differential expression of multiple kallikreins in a viral model of multiple sclerosis points to unique roles in the innate and adaptive immune response. Biol Chem 2014, 395, 1063-1073.

18. Kroksveen, A. C.; Aasebo, E.; Vethe, H.; Van Pesch, V.; Franciotta, D.; Teunissen, C. E.; Ulvik, R. J.; Vedeler, C.; Myhr, K. M.; Barsnes, H.; Berven, F. S. Discovery and initial verification 
of differentially abundant proteins between multiple sclerosis patients and controls using iTRAQ and SID-SRM. J Proteomics 2013, 78, 312-325.

19. Scarisbrick, I. A. The multiple sclerosis degradome: enzymatic cascades in development and progression of central nervous system inflammatory disease. Curr Top Microbiol Immunol 2008, 318, 133-175.

20. Blaber, S. I.; Ciric, B.; Christophi, G. P.; Bernett, M. J.; Blaber, M.; Rodriguez, M.; Scarisbrick, I. A. Targeting kallikrein 6 proteolysis attenuates CNS inflammatory disease. FASEB J 2004, 18, 920-932.

21. Yoon, H.; Blaber, S. I.; Evans, D. M.; Trim, J.; Juliano, M. A.; Scarisbrick, I. A.; Blaber, M. Activation profiles of human kallikrein-related peptidases by proteases of the thrombostasis axis. Protein Sci 2008, 17, 1998-2007.

22. Shaw, M. A.; Gao, Z.; McElhinney, K. E.; Thornton, S.; Flick, M. J.; Lane, A.; Degen, J. L.; Ryu, J. K.; Akassoglou, K.; Mullins, E. S. Plasminogen Deficiency Delays the Onset and Protects from Demyelination and Paralysis in Autoimmune Neuroinflammatory Disease. J Neurosci $2017,37,3776-3788$.

23. Balashov, K.; Dhib-Jalbut, S.; Rybinnik, I. Fibrinolysis induced clinical improvement in a patient with multiple sclerosis exacerbation. Mult Scler Relat Disord 2020, 43, 102225.

24. Masurier, N.; Arama, D. P.; El Amri, C.; Lisowski, V. Inhibitors of kallikrein-related peptidases: An overview. Med Res Rev 2018, 38, 655-683.

25. Prassas, I.; Eissa, A.; Poda, G.; Diamandis, E. P. Unleashing the therapeutic potential of human kallikrein-related serine proteases. Nat Rev Drug Discov 2015, 14, 183-202.

26. Masurier, N.; Soualmia, F.; Sanchez, P.; Lefort, V.; Roué, M.; Maillard, L.; Subra, G.; Percot, A.; El Amri, C. Synthesis of Peptide-Adenine Conjugates as a New Tool for Monitoring Protease Activity. Eur. J. Org. Chem 2019, 2019, 176-183. 
27. Loessner, D.; Goettig, P.; Preis, S.; Felber, J.; Bronger, H.; Clements, J. A.; Dorn, J.; Magdolen, V. Kallikrein-related peptidases represent attractive therapeutic targets for ovarian cancer. Expert Opin Ther Targets 2018, 22, 745-763.

28. Goettig, P.; Magdolen, V.; Brandstetter, H. Natural and synthetic inhibitors of kallikrein-related peptidases (KLKs). Biochimie 2010, 92, 1546-1567.

29. Sananes, A.; Cohen, I.; Shahar, A.; Hockla, A.; De Vita, E.; Miller, A. K.; Radisky, E. S.; Papo, N. A potent, proteolysis-resistant inhibitor of kallikrein-related peptidase 6 (KLK6) for cancer therapy, developed by combinatorial engineering. J Biol Chem 2018, 293, 1266312680.

30. De Vita, E.; Schuler, P.; Lovell, S.; Lohbeck, J.; Kullmann, S.; Rabinovich, E.; Sananes, A.; Hessling, B.; Hamon, V.; Papo, N.; Hess, J.; Tate, E. W.; Gunkel, N.; Miller, A. K. Depsipeptides Featuring a Neutral P1 Are Potent Inhibitors of Kallikrein-Related Peptidase 6 with On-Target Cellular Activity. J Med Chem 2018, 61, 8859-8874.

31. Soualmia, F.; Bosc, E.; Aït Amiri, S.; Stratmann, D.; Magdolen, V.; Darmoul, D.; ReboudRavaux, M.; El Amri, C. Insights into the activity control of the kallikrein-related peptidase 6: small-molecule modulators and allosterism. Biol Chem. 2018, 399, 1073-1078.

32. De Vita, E.; Smits, N.; van den Hurk, H.; Beck, E. M.; Hewitt, J.; Baillie, G.; Russell, E.; Pannifer, A.; Hamon, V.; Morrison, A.; McElroy, S. P.; Jones, P.; Ignatenko, N. A.; Gunkel, N.; Miller, A. K. Synthesis and Structure-Activity Relationships of N-(4-Benzamidino)Oxazolidinones: Potent and Selective Inhibitors of Kallikrein-Related Peptidase 6. ChemMedChem 2020, 15, 79-95.

33. Liang, G.; Chen, X.; Aldous, S.; Pu, S. F.; Mehdi, S.; Powers, E.; Xia, T.; Wang, R. Human kallikrein 6 inhibitors with a para-amidobenzylanmine P1 group identified through virtual screening. Bioorg Med Chem Lett 2012, 22, 2450-2455. 
34. Skaper, S. D. Oligodendrocyte precursor cells as a therapeutic target for demyelinating diseases. Prog Brain Res 2019, 245, 119-144.

35. Voet, S.; Prinz, M.; van Loo, G. Microglia in Central Nervous System Inflammation and Multiple Sclerosis Pathology. Trends Mol Med 2019, 25, 112-123.

36. Tamashiro, T. T.; Dalgard, C. L.; Byrnes, K. R. Primary microglia isolation from mixed glial cell cultures of neonatal rat brain tissue. J Vis Exp 2012, 15, e3814.

37. Bowes, J.; Brown, A. J.; Hamon, J.; Jarolimek, W.; Sridhar, A.; Waldron, G.; Whitebread, S. Reducing safety-related drug attrition: the use of in vitro pharmacological profiling. Nat Rev Drug Discov 2012, 11, 909-922.

38. Strauss, K. I. Antiinflammatory and neuroprotective actions of COX2 inhibitors in the injured brain. Brain Behav Immun 2008, 22, 285-98.

39. Katayama, K.; Arai, Y.; Murata, K.; Saito, S.; Nagata, T.; Takashima, K.; Yoshida, A.; Masumura, M.; Koda, S.; Okada, H.; Muto, T. Discovery and structure-activity relationships of spiroindolines as novel inducers of oligodendrocyte progenitor cell differentiation. Bioorg Med Chem 2020, 28, 115348.

40. Zaldivar-Diez, J.; Li, L.; Garcia, A. M.; Zhao, W. N.; Medina-Menendez, C.; Haggarty, S. J.; Gil, C.; Morales, A. V.; Martinez, A. Benzothiazole-Based LRRK2 Inhibitors as Wnt Enhancers and Promoters of Oligodendrocytic Fate. J Med Chem 2020, 63, 2638-2655.

41. Su, W.; Matsumoto, S.; Banine, F.; Srivastava, T.; Dean, J.; Foster, S.; Pham, P.; Hammond, B.; Peters, A.; Girish, K. S.; Rangappa, K. S.; Basappa, J. J.; Hennebold, J. D.; Murphy, M. J.; Bennett-Toomey, J.; Back, S. A.; Sherman, L. S. A modified flavonoid accelerates oligodendrocyte maturation and functional remyelination. Glia 2020, 68, 263-279.

42. Darensbourg, D. J.; Chung, W. C.; Arp, C. J.; Tsai, F. T.; Kyran, S. J. Copolymerization and Cycloaddition Products Derived from Coupling Reactions of 1,2-Epoxy-4-cyclohexene and 
Carbon Dioxide. Postpolymerization Functionalization via Thiol-Ene Click Reactions. Macromolecules 2014, 47, 7347-7353.

43. Tanaka, K. I.; Yoshifuji, S.; Nitta, Y. A New Method for the Synthesis of Amides from Amines : Ruthenium Tetroxide Oxidation of N-Protected Alkylamines. Chemical \& pharmaceutical bulletin 1988, 36, 3125-3129.

44. Gallo-Rodriguez, C.; Ji, X. D.; Melman, N.; Siegman, B. D.; Sanders, L. H.; Orlina, J.; Fischer, B.; Pu, Q.; Olah, M. E.; van Galen, P. J.; Stiles, G. L.; Jacobson, K. A. Structure-activity relationships of N6-benzyladenosine-5'-uronamides as A3-selective adenosine agonists. J Med Chem 1994, 37, 636-646.

45. Liang, G.; Chen, X.; Aldous, S.; Pu, S. F.; Mehdi, S.; Powers, E.; Giovanni, A.; Kongsamut, S.; Xia, T.; Zhang, Y.; Wang, R.; Gao, Z.; Merriman, G.; McLean, L. R.; Morize, I. Virtual Screening and X-ray Crystallography for Human Kallikrein 6 Inhibitors with an Amidinothiophene P1 Group. ACS Med Chem Lett 2012, 3, 159-164.

46. Olsson, M.; Søndergaard, C. R.; Rostkowski, M.; Jensen, J. H. PROPKA3: Consistent Treatment of Internal and Surface Residues in Empirical pKa Predictions. Journal of Chemical Theory and Computation 2011, 7, 525-537.

47. Morris, G. M.; Huey, R.; Lindstrom, W.; Sanner, M. F.; Belew, R. K.; Goodsell, D. S.; Olson, A. J. AutoDock4 and AutoDockTools4: Automated docking with selective receptor flexibility. J Comput Chem 2009, 30, 2785-2791.

48. Trott, O.; Olson, A. J. AutoDock Vina: improving the speed and accuracy of docking with a new scoring function, efficient optimization and multithreading. J Comput Chem 2010, 31, $455-461$. 
49. Kadukova, M.; Grudinin, S. Convex-PL: a novel knowledge-based potential for proteinligand interactions deduced from structural databases using convex optimization. J Comput Aided Mol Des 2017, 31, 943-958.

50. Wegener, A.; Deboux, C.; Bachelin, C.; Frah, M.; Kerninon, C.; Seilhean, D.; Weider, M.; Wegner, M.; Nait-Oumesmar, B. Gain of Olig2 function in oligodendrocyte progenitors promotes remyelination Brain 2015, 138, 120-135.

51. de Vellis, J.; Cole, R. Preparation of mixed glial cultures from postnatal rat brain. Methods Mol Biol 2012, 814, 49-59

52. Louis, J. C.; Magal, E.; Muir, D.; Manthorpe, M.; Varon, S. CG-4, a new bipotential glial cell line from rat brain, is capable of differentiating in vitro into either mature oligodendrocytes or type-2 astrocytes. J Neurosci Res 1992, 31, 193-204.

53. Huang, J. K.; Jarjour, A. A.; Nait Oumesmar, B.; Kerninon, C.; Williams, A.; Krezel, W.; Kagechika, H.; Bauer, J.; Zhao, C.; Baron-Van Evercooren, A.; Chambon, P.; Ffrench-Constant, C.; Franklin, R. J. M. Retinoid X receptor gamma signaling accelerates CNS remyelination. Nat Neurosci 2011, 14, 45-53. 
Table of content graphic

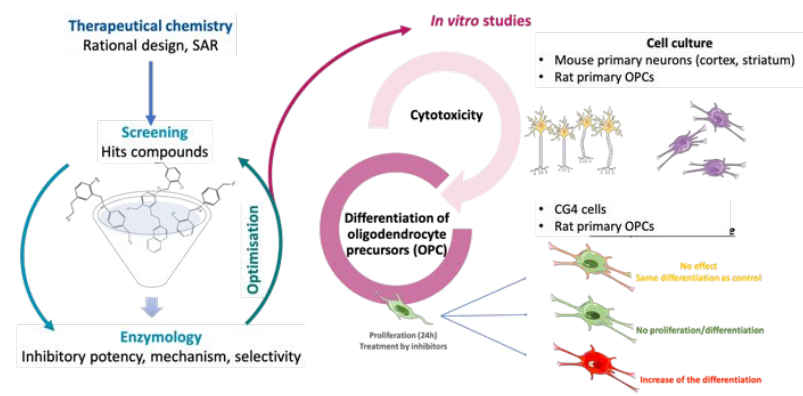

